UNIVERSIDADE DE SÃO PAULO

ESCOLA DE ENFERMAGEM DE RIBEIRÃO PRETO

\title{
Halitose em adolescentes de diferentes estratos sociais do município de Ribeirão Preto/SP
}

MARINA SÁ ELIAS PADILHA 


\section{Halitose em adolescentes de diferentes estratos sociais do município de Ribeirão Preto/SP}

Tese de Doutorado apresentada à Escola de Enfermagem de Ribeirão Preto da Universidade de São Paulo para a obtenção do título de Doutor em Enfermagem em Saúde Pública.

Área de concentração: Enfermagem em Saúde Pública. Inserido na linha de pesquisa: Assistência à Criança e ao Adolescente

Orientadora: Profa. Dra. Maria das Graças Bonfim de Carvalho

Ribeirão Preto 
AUTORIZO A REPRODUÇÃO E DIVULGAÇÃO TOTAL OU PARCIAL DESTE TRABALHO, POR QUALQUER MEIO CONVENCIONAL OU ELETRÔNICO, PARA FINS DE ESTUDO E PESQUISA, DESDE QUE CITADA A FONTE.

Catalogação na Publicação

Serviço de Documentação da Enfermagem

Escola de Enfermagem de Ribeirão Preto da Universidade de São Paulo

Elias Padilha, Marina Sá

Halitose em adolescentes de diferentes estratos sociais do município de Ribeirão Preto / Marina Sá Elias Padilha; orientadora: Profa. Dra. Maria das Graças Bonfim de Carvalho. Ribeirão Preto, 2006.

164p.

Tese (Doutorado) - Programa de Pós-Graduação de Enfermagem em Saúde Pública. Área de Concentração: Assistência à Criança e ao Adolescente - Escola de Enfermagem de Ribeirão Preto da Universidade de São Paulo.

1. Halitose. 2. Adolescente. 


\section{FOLHA DE APROVAÇÃO}

\section{Marina Sá Elias Padilha}

Halitose em adolescentes de diferentes estratos sociais do município de Ribeirão Preto/SP

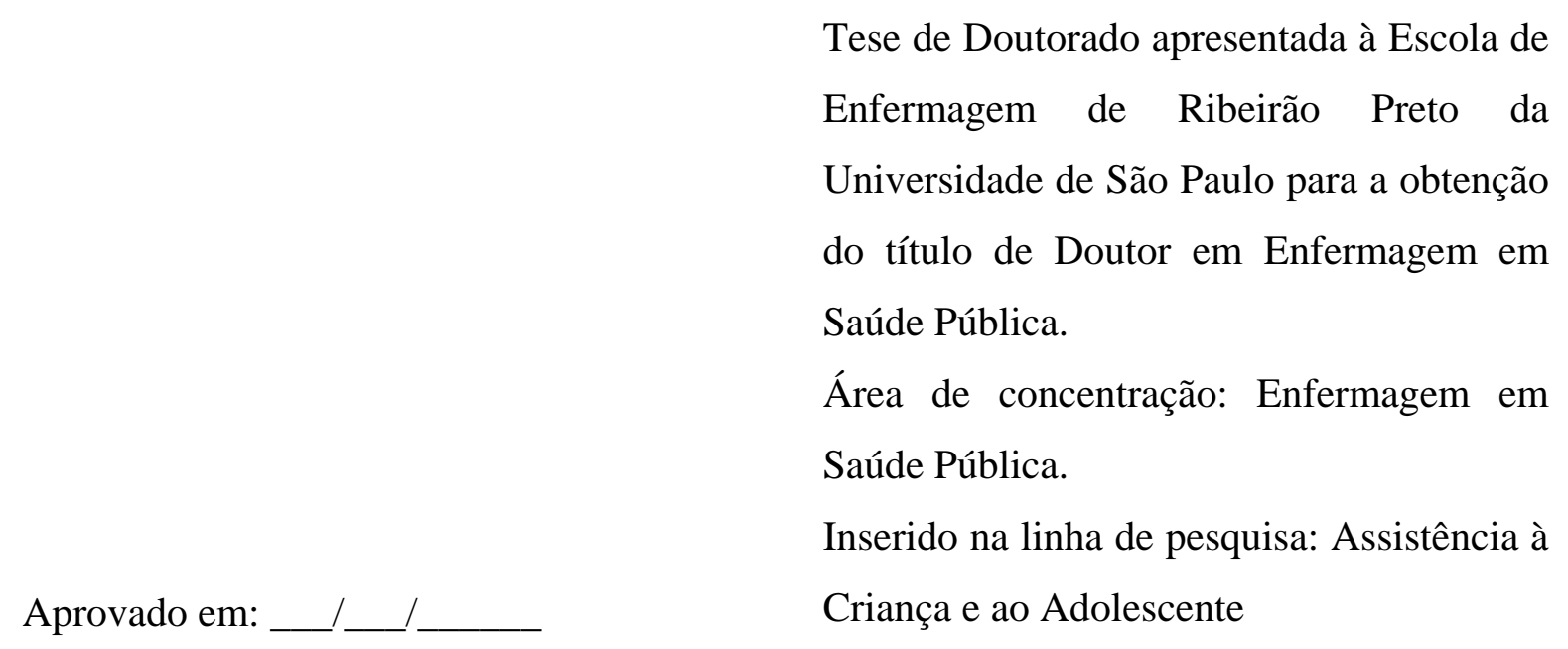

Banca Examinadora

Prof. Dr.

Instituição: Assinatura

Prof. Dr.

Instituição: Assinatura

Prof. Dr.

Instituição: Assinatura

Prof. Dr.

Instituição: Assinatura

Prof. Dr.

Instituição: Assinatura 
Esta tese teve para sua execução o auxílio concedido pelo Conselho Nacional de Desenvolvimento Científico e Tecnológico (CNPq) 


\section{AGRADECIMENTOS}

a Deus pela vida.

Aas meus pais que sempre sãa a meu parta segura.

Aa Paula, meu irmãa, que, par meia de seu vasta canhecimenta em infarmática, deu as supartes necessárias para a elabaraçãa deste estuda.

Aa Alexandre, meu marida, que, cam a sua tranqüilidade, me acalmaua nas mamentas mais urgentes, ande a ansiedade superaua a praduçãa.

A minha irmã e amiga Márcia, par me auxiliar em tadas as necessidades.

a Profa. Dra. Maria das Graças Banfim de Carwalha, pela arientaçãa abjetiva, competente e carinhasa. Obrigada pela apaia e incentiva.

A minha amiga Milla Finatti, que, cam seus canhecimentas de futura psicálaga me deu sugestães valiasas.

Aa Praf. Dr. Rameu Games pelas arientaçães acerca da metadalagia.

Aas professares e funcianárias da Escala de Enfermagem de Rileirãa Preta da Universidade de Sãa Paula.

A tadas aqueles que direta au indiretamente participaram e calabararam para a realizaçãa deste tralealha. 


\section{RESUMO}

ELIAS PADILHA, M. S. Halitose em adolescentes de diferentes estratos sociais do município de Ribeirão Preto. 2006. 164p. Tese (Doutorado). Escola de Enfermagem de Ribeirão Preto. Universidade de São Paulo.

A relação dos odores bucais com os aspectos sociais sempre foi um fator de preocupação para a sociedade, no entanto, verificamos que apesar de existirem inúmeros trabalhos sobre a halitose na literatura nacional e internacional, poucos abordam aspectos sociais e psicológicos, principalmente em relação aos adolescentes. Este estudo teve por objetivo geral compreender como a halitose é vivenciada entre adolescentes e os reflexos na sua qualidade de vida. E como objetivos específicos: identificar os significados atribuídos pelos adolescentes à halitose e às pessoas que vivenciam tal problema; identificar o conhecimento que os adolescentes têm sobre a halitose e quais meios utilizam frente a mesma; e analisar os reflexos da halitose entre adolescentes na sua qualidade de vida. Realizamos uma construção histórico-social sobre a halitose que também abordou aspectos de sua fisiopatologia. O referencial teórico adotado foi baseado em conceitos sobre adolescência e qualidade de vida. O referencial metodológico é de natureza qualitativa. Para a coleta de dados, foi utilizada entrevista semi-estruturada, e o tratamento dos dados baseou-se na análise de conteúdo. Encontramos nas temáticas: "Halitose como um problema para o adolescente" e "Cuida da sua boca senão vai levar um fora” elementos que responderam aos nossos pressupostos de que esta patologia limita a qualidade de vida de adolescentes. E como consideramos a promoção da saúde um modo de se obter qualidade de vida, sugerimos a educação em saúde como meio para atingir tal objetivo.

PALAVRAS CHAVE: Halitose. Adolescente. 


\begin{abstract}
ELIAS PADILHA, M. S. Halitosis in adolescents of different social strata in the city of Ribeirão Preto. 2006. 164p. Thesis (Doctorate). Nursing's School of Ribeirão Preto. Universtity of São Paulo.

The relationship of the buccal odors with the social aspects was always a concern factor for the society, however, we verified countless halitosis works in the national and international literature, few approaches social and psychological aspects, mainly in relation to the adolescents. This study had for general objective, to understand as the halitosis is lived between adolescents and the reflexes in their life quality. And as specific objectives: to identify the meanings attributed by the adolescents to the halitosis and the people that live such problem; to identify the halitosis knowledge that the adolescents has and which means that they use front this problem; and to analyze the reflexes of halitosis on adolescents life quality. We accomplished a halitosis historical-social construction with aspects of treatment, prevention and etiology. The theoretical referential used was based in concepts about adolescence and quality of life. The qualitative methodology was used. For data collection semi-structured interview was used and the data treatment was based in content's analysis. We found in the themes: "Halitosis as a problem for the adolescent" and "Be careful with your mouth or get lost" elements that answered to our presuppositions that this pathology limits the quality of adolescents' life. And how we considered the promotion of the health a way of obtaining life quality, we suggested the education in health as middle to reach such objective.
\end{abstract}

\title{
KEYWORDS: Halitosis. Adolescent.
}




\section{RESUMEN}

ELIAS PADILHA, M. S. Halitosis en adolescentes de diferentes extractos sociales del Municipio de Ribeirão Preto. 2006. 164p. Tesis (Doctorado). Escuela de Enfermería de Ribeirão Preto. Universidad de São Paulo.

La relación de los olores bucales con los aspectos sociales siempre era un factor de preocupación para la sociedad, sin embargo, que nosotros verificamos que la halitosis innumerable trabaja en la literatura nacional e internacional, solamente algunos acercan aspectos sociales y psicológicos, principalmente respecto a los adolescentes. Este estudio tuvo por objetivo general, entender como la halitosis se vive entre los adolescentes y los reflejos en su calidad de vida. Y como los objetivos específicos: para identificar los significados atribuidos por los adolescentes a la halitosis y las personas que viven el tal problema; para identificar el conocimiento de la halitosis que los adolescentes tienen y qué medios que ellos usan el frente este problema; y para analizar los reflejos de halitosis en la calidad de vida de adolescentes. Nosotros logramos una construcción histórico-social de la halitosis con los aspectos de tratamiento, prevención y etiology. El referente teórico adoptado está basado en conceptos sobre adolescencia, promoción de salud y calidad de vida. El referente metodológico es de naturaleza cualitativa. Para la recogida de datos se utilizó entrevista semiestructurada y el tratamiento de los datos se basó en la análisis de contenido. Nosotros encontramos en los temas: La "halitosis como un problema para el adolescente" y "Tiene el cuidado con su boca o se pierde" elementos que contestaron a nuestras presuposiciones que esta patología limita la calidad de la vida de adolescentes. Y como consideramos la promoción de la salud un modo de obtener calidad de vida, sugerimos la educación en salud como medio para alcanzar tal objetivo.

PALABRAS CLAVE: Halitosis. Adolescente. 


\section{LISTA DE FIGURAS}

Figura 1. Antigo raspador de língua hindu, confeccionado em prata

Figura 2. Halimeter

Figura 3. Raspador lingual

40

Figura 4. Demonstração de placa bacteriana corada por meio de evidenciadores de placa

Figura 5. Conceituação de qualidade de vida - (FELCE; PERRY, 1996)

Figura 6. Educação - média de anos de estudos da população de 15 a 64 anos, Estado de São Paulo, Região de Governo de Ribeirão Preto e município de Ribeirão Preto, 2000

Figura 7. Mapa com a estratificação social em que as escolas sorteadas estão sinalizadas por meio de círculos brancos 


\section{LISTA DE TABELAS}

Tabela 1. Doenças e os odores característicos gerados

Tabela 2. Perfil do município de Ribeirão Preto 67 


\section{RESUMO}

ABSTRACT

RESUMEN

LISTA DE FIGURAS

LISTA DE TABELAS

1. CONSTRUINDO O OBJETO DE ESTUDO

1.1 A escolha e delimitação do objeto

2. HALITOSE

2.1 Aspectos históricos e sociais da halitose

2.2 Classificação dos odores

25

2.3 Fisiologia da sensibilidade olfatória

2.4 Conceitos e etiologia da halitose

2.5 Classificação

2.6 Diagnóstico e epidemiologia

2.7 Prevenção e tratamento

39

3. OBJETIVOS

3.1 Objetivo geral

3.2 Objetivos específicos

4.1 Adolescência 49

4.2 Qualidade de vida 57

4.3 Pressupostos

5.1 Caracterização da pesquisa 
5.3 Sujeitos do estudo

5.4 Instrumentos para coleta de dados ..................................................... $\quad 75$

5.5 Aspectos éticos da pesquisa ............................................................ 77

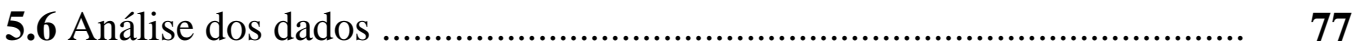

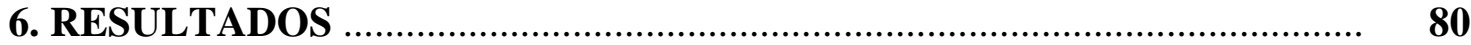

6.1 "Halitose como um problema para o adolescente” .......................... 82

6.1.1 "Boca de bueiro" ................................................................ 82

6.1.2 "Sai de perto" ....................................................................... $\quad 86$

6.1.3 “Ela não se toca que tem mau hálito?” .......................................... 94

6.2 “Cuida da sua boca senão vai levar um fora” .................................. 99

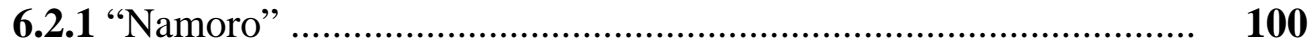

6.2.2 “Conhecimento" .................................................................. 104

6.2.3 “Como enfrenta a situação” (prevenção) .................................... 109

7. PROMOÇÃO DA SAÚDE COMO CAMINHO PARA A QUALIDADE

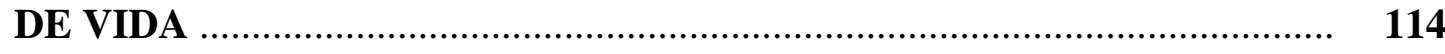

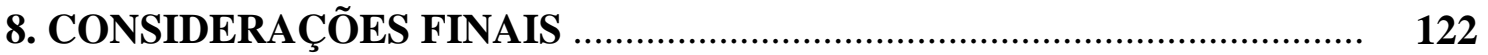

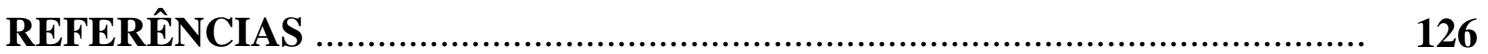

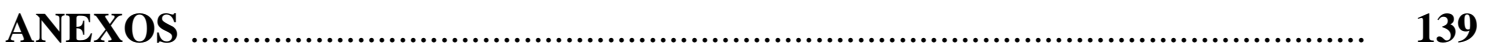


1 Construindo o objeto de estudo 


\section{CONSTRUINDO O OBJETO DE ESTUDO}

\subsection{A escolha e delimitação do objeto}

A motivação para esta pesquisa originou-se dos dados obtidos na dissertação de mestrado, quando foi estudada a importância da saúde bucal para adolescentes de diferentes estratos sociais (ELIAS, 2000). Os resultados do referido estudo mostravam que dentes cariados, ausentes, e ainda o problema de halitose são fatores de grande influência na saúde bucal, prejudicando o convívio social do adolescente e influenciando de forma negativa sua auto-imagem. Por meio desse estudo também foi possível conhecer as motivações que os levam a cuidarem de sua saúde bucal, tais como: aparência pessoal, sexualidade, emprego e saúde geral.

Desde então, no decorrer da experiência pessoal durante a docência na graduação do curso de Odontologia da Universidade de Franca na disciplina de Estágio Supervisionado, onde eram realizadas visitas a escolas de municípios próximos a Franca para a realização de promoção da saúde por meio da saúde bucal, foi possível uma maior aproximação da população adolescente, de onde surgiram as inquietações a respeito das limitações que a halitose poderia trazer à adolescência.

Trabalhando nesta disciplina foi possível observar como a halitose se torna um problema para o adolescente que a possui, quando origina chacota e zombaria pelos outros, ou ainda desconforto para aqueles que convivem com tais pessoas. Surgindo indagações de como seria afetado esse período tão importante no desenvolvimento humano.

A halitose é uma patologia de origem bucal em 90\% dos casos, principalmente devido à presença de saburra lingual, em que os principais microorganismos formadores presentes são do tipo anaeróbios proteolíticos, os quais produzem componentes de cheiro desagradável no final de seu metabolismo (SALVADOR; FIGUEIREDO, 2001; MENINGAUD et al., 
1999; SANZ; ROLDÁN; HERRERA, 2001; HINE, 1957). E pelo fato da saburra não ser contagiosa, torna-se comum que apenas um dos parceiros apresente hálito muito desagradável, a ponto de incomodar o outro.

No que diz respeito à sexualidade, não se pode deixar de citar o beijo, uma manifestação de carinho que pode ser prejudicada, se a boca apresentar mau hálito. Sayão (1997) considera a boca como uma parte do corpo que, mesmo não sendo um órgão sexual, é capaz de dar e produzir muitas sensações eróticas; e que uma das primeiras carícias mais íntimas entre duas pessoas que sentem atração uma pela outra, ou que se gostam é o beijo. O beijo na boca é excitante e também expressão de afeto e intimidade, e, segundo Werebe (1998), os odores corporais constituem fator de atração sexual.

Desde os primeiros estudos de Freud (1972), já era feita a ligação da boca com aspectos psicológicos do ser humano. Pela visão holística do paciente, supõe-se que o comprometimento da saúde bucal pode causar problemas para adolescentes, sendo a boca um local tão repleto de funções e significados.

Tiba (1986) aborda o relacionamento social-afetivo-sexual como etapa muito importante na vida do adolescente, pois resulta de uma série de modificações físicas e transpsíquicas que traz à tona a auto-imagem, a auto-estima e a expectativa de futuro. Em virtude disso, um adolescente que possua a saúde bucal comprometida pode ter prejudicado seu relacionamento afetivo.

Além de tudo isso, o adolescente tem a necessidade de ser aceito pelo grupo, em círculos de amizade e convívio social. Ashley (1989) assegura que a aceitação social está relacionada à aparência, à habilidade de falar claramente e à ausência de halitose. A turma representa um grande passo no sentido da socialização comunitária do adolescente, é a busca de seu átomo social. Pessoas que sofrem de halitose criam uma barreira social entre eles e seus amigos, familiares, cônjuge ou colegas de trabalho (BOSY, 1997). 
Na amplitude deste campo de investigação, buscamos conceituar a halitose, explicitar sua fisiopatologia, assim como também trazer aspectos sociais e históricos sobre o assunto.

Pois Laplantine (1991) afirma que uma das formas de se conhecer um objeto de estudo é traçar-lhe a história e a cultura, mostrando como foi variando suas cenas através do tempo e mostrando perspectivas atuais, dessa forma, é possível compreender melhor as suas características específicas, apresentando tendências contemporâneas e um panorama dos problemas evidenciados na vivência cotidiana e as possibilidades de intervenção e atuação. Presos a uma única cultura, somos não apenas cegos à dos outros, mas míopes quando se trata da nossa.

Verificamos que existem inúmeros trabalhos sobre a halitose na literatura nacional e internacional, no entanto, notamos uma deficiência de abordagem dos aspectos sociais e psicológicos. Principalmente em relação aos adolescentes.

Apesar de a incidência de halitose ser maior nos pacientes idosos, os aspectos psicológicos, a insegurança e necessidade de aceitação se tornam fatores relevantes para considerar a faixa etária da adolescência neste estudo.

Considerando este dentre os fatores supracitados, foi idealizado que a adolescência seria o período ideal para fazer o recorte deste estudo. Baseando-se no fato de que é nesta fase que ocorrem as descobertas, envolvimentos afetivos e sexuais e o contato físico mais próximo.

E para o desenvolvimento deste estudo, foi realizado um recorte analítico que contempla aspectos singulares do adolescente, bem como sobre qualidade de vida.

A relevância dada a este assunto se apresenta, uma vez que a presença de halitose pode afetar a qualidade de vida do adolescente em sua plenitude. Principalmente em relação aos fatores psicossociais que Pereira (1998) considera como um dos diversos elementos que formam este constructo multidimensional. 
E somando a isso, existe o fato de que a etiologia da halitose na maioria das vezes se trata de biofilme que também é um dos múltiplos fatores etiológicos que levam à doença cárie e à doença periodontal. E dessa forma, é possível trazer subsídios para a elaboração de estratégias educativas e de ação junto ao grupo de adolescentes, objetivando saúde bucal e abrangendo várias patologias ao mesmo tempo.

Para equacionar o problema da halitose, acredita-se conseguir alcançar a promoção da saúde através da educação em saúde. Vale comentar que, em função da incipiente educação em saúde fornecida pelos profissionais de saúde, no que diz respeito à halitose, não se torna possível a promoção da saúde.

Educação em saúde expressa um processo com dimensões intelectuais, psicológicas e sociais, relativo a atividades que aumentam as habilidades das pessoas em tomar decisões que afetam seu bem-estar pessoal, de sua família e de sua comunidade (DeBIASE, 1991). A orientação, a prevenção e a identificação precoce de possíveis enfermidades já instaladas são, em odontologia, meios comprovadamente eficazes para se obter saúde. Delangue et al. (1999) sugerem que uma melhor educação sobre a causa mais comum de mau odor, que é a higiene oral insuficiente, deveria ser empreendida.

Concluindo, o problema da halitose pode se apresentar de maior magnitude em termos de reflexos na qualidade de vida dos adolescentes, o que justifica a realização deste trabalho.

Com base no exposto surgiram as seguintes questões que nortearam nosso estudo: A halitose afeta as relações interpessoais e conseqüentemente os relacionamentos afetivos dos adolescentes, interferindo no desenvolvimento de sua sexualidade? Se este problema afeta a qualidade de vida? Qual o significado da halitose para os adolescentes? Que estratégias os adolescentes utilizam para se cuidar?

Diante do que foi apresentado, consideramos como objeto de estudo, as implicações sociais e psicológicas que a halitose pode provocar entre adolescentes. 


\section{Halitose}

O olfato é um mágico poderoso que nos transporta, percorrendo a distância de milhares de milhas e de todos os anos que vivemos. 


\section{HALITOSE}

\subsection{Aspectos históricos e sociais da halitose}

Os odores nos afetam em níveis físico, psicológico e social. Somente quando a nossa faculdade olfativa está prejudicada por alguma razão, é que começamos a perceber o papel essencial que a olfação desempenha em nossa sensação de bem-estar (CLASSEN; HOWES; SYNNOTT, 1996). O olfato não é um fenômeno simplesmente biológico e psicológico. É também um fenômeno cultural, social e histórico.

Responsáveis pelas mais fortes sensações que o corpo é capaz de proporcionar, os orifícios corporais e as atividades a eles relacionadas configuram um domínio em que opera fortemente o imaginário, inclusive por estarem intimamente relacionados à sexualidade. Pelo poder extremamente forte de evocação, de metáfora, de símbolo e de analogia que detêm (Peter, $1986^{1}$ apud ANDRADE LIMA, 1996, p.53).

Classen, Howes e Synnott (1996) afirmam que o cheiro pode provocar fortes reações emocionais, pois uma fragrância associada a uma boa experiência pode ocasionar uma torrente de alegria, enquanto um cheiro fétido pode nos remeter a uma lembrança infeliz. Os odores são pistas essenciais na criação e conservação de vínculos sociais, pois estão impregnados de valores culturais. Os códigos olfativos com freqüência servem também para dividir e oprimir seres humanos. Um fato que exemplifica tal situação é que antigamente a cor púrpura usada somente no vestuário da realeza e da aristocracia por causa de seu alto custo, tinha um odor desagradável do molusco em decomposição do qual era extraído. Neste caso, o odor desagradável tinha um significado de exclusividade. Mas, de um modo geral, por meio dos odores perfumados era que se buscava a diferenciação.

\footnotetext{
${ }^{1}$ PETER, J. P. L`imaginaire des maladies: histoire et imaginaire. Paris: Poiesis-Payot, 1986.
} 
Acreditava-se que, nos maus odores, se concentram os ares corrompidos responsáveis pelas doenças. O perfume preservaria mais profundamente do contágio, corrigindo a corrupção do ar, os odores sedutores seriam o inverso das podridões. Aparentar limpeza era mais importante do que de fato estar limpo, o perfume é um instrumento modelar nessa arte da aparência. Era utilizada água de canela mantida na boca para assegurar ao hálito “um bom cheiro” (VIGARELLO, 1996).

A classificação daquilo que é mau cheiro é relativa, pois depende da cultura, da idade e do gosto pessoal de quem o avalia. Os ocidentais acham o cheiro fecal repulsivo, enquanto os masais gostam de enfeitar seus cabelos com estrume de vaca, o que lhes dá tom alaranjado e odor excitante (ACKERMAN, 1992).

Bosy (1997) nos lembra que o problema da halitose é relatado há muitos anos, havendo referências que datam de 1550 a.C., ainda em papiros, e também de Hipócrates que dizia que toda moça deve ter um hálito agradável, tendo o cuidado de sempre lavar sua boca com vinho, erva-doce e sementes de endro.

Os romanos sempre tiveram grande preocupação com os odores corporais e, ainda hoje, podemos ver as ruínas dos seus suntuosos banhos e termas. O banho era um ritual que se iniciava com uma sessão de transpiração no sudatorium, faziam um banho morno no tepidarium e depois esfriavam nadando na piscina do frigidarium. Terminada esta parte, se dirigiam ao unctarium, a sala de ungüentos, onde recebiam massagem com óleos perfumados.

Um importante foco dessa preocupação com os odores do corpo era o hálito, pois assim como um beijo perfumado era um ideal romântico, o mau hálito fazia com que o indivíduo fosse alvo de repugnância e zombaria. Eram utilizados mecanismos para mascarar o problema, como pastilhas perfumadas, mascar folhas e talos de plantas. Ter um hálito fragrante, na Antigüidade, era exalar a doçura da vida e atestar a pureza de alma de uma pessoa. Já no cristianismo, o supremo odor maligno emitido pelo diabo possui cheiro de 
enxofre, e ainda presumia-se que os pecados emitiam mau cheiro, em menor ou maior grau (CLASSEN; HOWES; SYNNOTT, 1996). Associação complexa, pois muitas vezes o odor predominante na halitose é o de enxofre.

Os deuses da mitologia grega e romana associados ao amor, como Afrodite, Eros ou Vênus e Cupido, eram não só portadores, eles próprios, de suaves aromas como também se aproximavam de pessoas cheirosas. Na Antigüidade, usavam-se fragrâncias não só para fins de atração pessoal, mas também como importante ingrediente para tudo, desde banquetes a desfiles e funerais, passando pelos eventos esportivos (CLASSEN; HOWES; SYNNOTT, 1996).

Ring (1998) afirma que sob a influência romana, os gregos aprenderam a usar uma enorme quantidade de substâncias para limpeza dos dentes, entre elas talco de pedra-pomes, esmeril, alabastro moído, coral em pó e óxido de ferro. Diocles de Caristo, um médico ateniense, contemporâneo de Aristóteles, aconselhava: - "A cada manhã deveis esfregar vossas gengivas e dentes com os dedos desnudos e com menta finamente pulverizada, por dentro e por fora, e em seguida deveis retirar todas as partículas de alimento aderidas". Quando tinham convidados para a ceia, estes recebiam, além de talheres, palitos de metal finamente decorados, amiúde confeccionados em ouro, e que eles levavam para suas casas como lembrança. E era considerado de bom tom a limpeza dos dentes à mesa.

Os japoneses no século VI realizavam a higiene bucal através de uma escova de ramos finos e a raspagem da língua antes das primeiras orações matinais. Um tratado da literatura islâmica do ano de 850 discorre brevemente sobre odontologia, fazendo referências ao tratamento de hálito fétido. Assim como outras práticas também eram realizadas no tempo de Maomé, como a recomendação do uso do siwak², quando o hálito estivesse mudado ou em

\footnotetext{
${ }^{2}$ siwak - ramo de uma árvore, cuja madeira contém bicarbonato de sódio e ácido tânico, além de outros adstringentes, que têm efeitos benéficos para a saúde bucal.
} 
qualquer momento ao levantar-se da cama (RING, 1998). Recomendação provavelmente direcionada a minimizar o odor da halitose matinal ou fisiológica.

Polo (1997), em seu diário de viagens, relata curiosidades e características de cada região por ele percorrida. Cita que, por volta de 1298, na região dos Tártaros, o hábito do Grão-senhor dos senhores Kublai Khan (Mongólia) de ordenar que sejam relacionadas as mais belas virgens, que são guardadas no palácio por mulheres que devem com elas dormir no mesmo leito para saber se têm bom hálito, se são virgens e bem sãs de todas as coisas.

Nas escavações arqueológicas realizadas em depósitos de lixo provenientes do século XIX, foram encontrados potes em faiança de pós dentifrícios, em geral franceses. Anúncios de época veiculavam as propriedades dos "pós dentifrícios vegetais", "pós dentifrícios chineses", "elixires dentifrícios", "águas balsâmicas para os dentes", "opiatos dentifrícios", confirmando um especial interesse pela eliminação do mau hálito e pelo asseio da boca (ANDRADE LIMA, 1996).

Ackerman (1992) refere que mulheres vitorianas tinham o hábito de adocicar o hálito com catechus, pastilhas feitas com gotas de extrato de violetas, especialmente quando bebiam.

De modo geral, até meados do século XIX supunha-se que as águas aromatizadas tivessem propriedades medicinais, curativas e prevenissem infecções. Inúmeras virtudes eram-lhes atribuídas: verdadeiros elixires da vida preservavam a juventude e a beleza, aliviavam dores, perfumavam hálitos. Ingeridas como cordiais ${ }^{3}$, aspergidas no ambiente, inaladas em lenços, passadas sobre a pele e as roupas, eram usadas tanto por homens quanto por mulheres. Sua maior popularidade foi atingida na segunda metade do referido século (Sullivan, $1994^{4}$ apud ANDRADE LIMA, 1996, p.84).

\footnotetext{
${ }^{3}$ Medicamento que ativa a circulação sangüínea, que restaura as forças, que robustece, elixir muito empregado na terapêutica antiga. (HOUAISS - Dicionário eletrônico da língua portuguesa, 2004)

${ }^{4}$ SULLIVAN, C. Searching for nineteenth-century Florida Water bottles. Historical Archaeology, v.28, n.1, p.78-98, 1994.
} 
No decorrer do século XIX, as emanações resultantes da atividade interna do corpo que, em momentos anteriores foram relativamente toleradas, tornaram-se insuportáveis. A ideologia de higienização que foi se instalando gradativamente provocou consideráveis mudanças na sensibilidade olfativa da época, o que forçou uma completa domesticação dos odores e produtos decorrentes dos processos metabólicos. Maus hálitos, maus cheiros, suores fétidos, ruídos intempestivos e os processos de excreção, entre outros, foram progressivamente submetidos a controles cada vez mais rígidos, filtrados pela vigilância e pela disciplina. Surgiu uma nova etiqueta corporal cuja palavra de ordem passou a ser a discrição (Le Breton, $1990^{5}$ apud ANDRADE LIMA, 1996, p.126).

Certos odores passaram a ser rechaçados pelas conveniências. O alho que já tinha sido a "verdadeira carne do soldado", considerado o verdadeiro cordial do povo, que dava-lhe coragem para lutar, deixou de ser utilizado devido ao seu odor, sendo substituído pela mirra. Também odores penetrantes e duradouros, encarregados de preservar a boca em tempos de peste, passam a ser substituídos pelos suaves (VIGARELLO, 1996).

O único tratado sobre a halitose foi escrito em 1874 por Howe, no qual ele afirma que o hálito ofensivo deriva sua importância do fato de se tornar uma fonte constante de infelicidade para o paciente, e é ainda pior quando destrói a comunicação entre amigos e os prazeres dos contatos sociais. Este tratado parece ter sido bem recebido, pois foi editado pelo menos três vezes (ROSENBERG, 2003; HINE, 1957).

Em relação aos aspectos religiosos, os judeus durante o Sabá, normalmente não podiam carregar objetos, por ser um dia sagrado de descanso. No entanto, curiosamente era liberado às mulheres sair com um grão de pimenta em sua boca para aromatizar seu hálito, mas se essa mulher tivesse uma coroa dental de ouro teria que deixá-la em casa (RING, 1998). Fato interessante, visto que a mastigação e a estética podiam ficar comprometidas, mas

\footnotetext{
${ }^{5}$ LE BRETON, D. Anthropologie du corps et modernité. Paris: PUF, 1990.
} 
o hálito não. Um outro exemplo vem do Talmude, ao relatar que diante de algumas condições, como, por exemplo, o mau odor de um dos parceiros, há a possibilidade de se quebrar legalmente a licença de matrimônio, o Ketuba (SANZ; ROLDÁN; HERRERA, 2001).

Já os hindus consideram a boca como porta de entrada do corpo e, portanto, insistem em mantê-la limpa, principalmente antes das suas orações. O ritual não se limita a escovar os dentes, mas também existem a raspagem da língua com um instrumento especial (Figura 1) e o uso de bochechos. Os monges budistas no Japão também preconizavam a escovação dos dentes e a raspagem da língua, antes das primeiras orações matinais (RING, 1998).

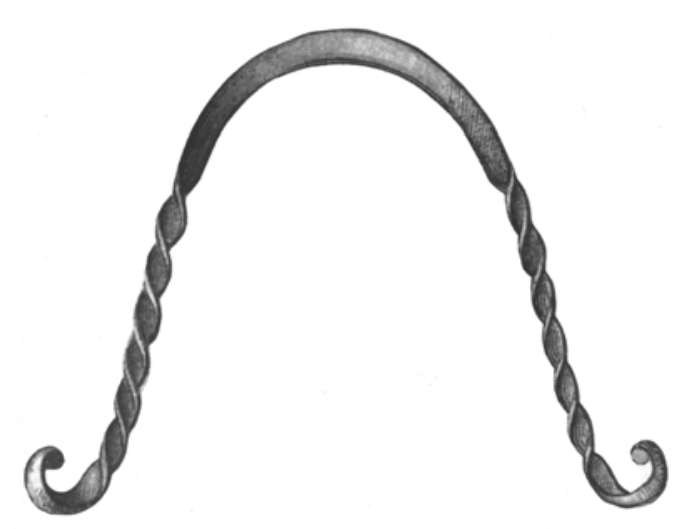

Figura 1. Antigo raspador de língua hindu, confeccionado em prata. Fonte: RING, 1998, p.74.

Interessante ressaltar que a higiene oral complementada pela raspagem da língua já era realizada há muitos anos e, no entanto, esta prática de raspagem, apesar de eficaz raramente é prescrita e ensinada pelos dentistas atuais.

Na medicina popular, em casos de mau hálito recomenda-se mascar folhas, cascas ou raízes de aperta-ruão (Piper aduncum) para perfumar a boca (ROSENTHAL, 1998). 
Atualmente já existe no mercado formal, uma infinidade de produtos destinados a mascarar o mau hálito, tais como: balas, chicletes, soluções orais e até sprays.

\subsection{Classificação dos odores}

Odor pode ser definido como a qualidade de uma substância ou mistura ser percebida na inalação pelo nariz, ou ainda pelo nariz por meio da boca, pela forma volátil, sem contato físico com a substância (HINE, 1957).

Existe uma grande dificuldade em classificar os odores, normalmente com a tentativa de minimizar tal problema, são utilizadas metáforas e descrições para designá-los. A diferenciação primária é feita entre os agradáveis e os desagradáveis. A ausência de um verdadeiro vocabulário olfativo nas línguas européias tem preocupado há muito tempo os cientistas ocidentais. Embora o nariz humano seja capaz de reconhecer milhares de diferentes odores, quase todas as nossas características de odor - suave, penetrante, azedo dentre outros são tomadas a partir de uma seleção limitada de termos gustativos. Ou são designados tomando-se como referência as coisas dos quais emanam, por exemplo: cheiro de café, de tinta fresca, entre outros (CLASSEN; HOWES; SYNNOTT, 1996).

Wijk, Schab e Cain (1995) acreditam que nossa "possivelmente fraca" performance em identificar odores seja atribuída à ausência de um vocabulário próprio para designar os odores. Talvez pelo fato de que em nossa vida diária a percepção dos odores é rica e cheia de significados, e o que cheiramos é o que já se esperava pela imagem visual ou contextual, ordinariamente, odores servem para apoiar ou confirmar identificação de objeto. Ackerman (1992) chega a chamar o olfato de um sentido mudo, que não tem palavras. Tal a dificuldade existente em encontrar palavras para designar odores. 
Têm sido sugeridas muitas classificações, sendo uma delas: fragrante, etéreo ou frutal, resinoso, picante, pútrido e queimado, tal representação classifica odores primários, sendo todas as outras combinações destes (BRADLEY, 1981).

Zwaardemaker $^{6}$ (1926 apud HINE, 1957, p.39) classifica os odores como:

a) Etéreo ou de fruta: característico em geral das frutas, e na maioria dos casos, à presença de vários ésteres; inclui também a cera de abelha e certos ésteres, aldeídos e cetonas.

b) Aromáticos:

Canforáceos: borneol, cânfora e eucaliptol.

Condimentado: eugenol, gengibre, pimenta, canela, cássia e macis ${ }^{7}$

Erva-doce-lavanda: anetol, lavanda, mentol, timol e safrol.

Limão-rosa: geraniol, cítrico, acetato de linalil e sândalo.

Amigdalina: benzaldeído, óleo de amêndoas amargas, nitrobenzeno, salicilaldeído e ácido prússico.

c) Fragrante ou balsâmico:

Floral: jasmim, lírio do vale e flor de laranjeira.

Lírio: narciso, violeta, jacinto dentre outras.

Balsâmico: baunilha, piperonal, cumarim, bálsamo do Peru e bálsamo de Tolu.

d) Ambrosial: almíscar e âmbar: Este odor está presente na carne, no sangue e excretas (bile) de certos animais.

Hine (1957) também cita a classificação de Henning's:

a) Condimentado: facilmente notado no cravo-da-índia, canela e na nozmoscada.

b) Floral: evidente no heliotrópio e jasmim.

c) Frutal: próprio da maçã, óleo de laranja e vinagre.

d) Resinoso: óleo de coníferas e terebintina.

e) Fétido: próprio de compostos de sulfidreto.

f) Queimado: evidente em objetos chamuscados.

\footnotetext{
${ }^{6}$ Zwaardemaker, H. Odoriferous materials. In: International critical tables of numerical data. Physics, chemistry and technology. National research Council. New York: MaGraw-Hill Book Co., 1926, 358p.

${ }^{7}$ Arilo carnoso da noz-moscada, óleo que se extrai desse arilo e é usado sobretudo como condimento ou essência. O pó obtido das fibras desse arilo, de odor entre a canela e a pimenta-do-reino, usado como tempero e aromatizante.
} 
Ackerman (1992) agrupa os cheiros em categorias básicas: mentolado (hortelã), floral (rosas), etéreos (peras), almiscarado (almíscar), resinoso (cânfora), desagradável (ovo podre) e acre (vinagre).

A visão mecanicista e reducionista de observar o corpo humano de Descartes deixava claro que o sentido da ciência seria a visão, e essa posição foi fortalecida nos séculos seguintes. Os cheiros, tão difíceis de medir, denominar ou recriar, estavam indubitavelmente entre os estímulos sensoriais menos acessíveis aos métodos da ciência (CAPRA, 1982; CLASSEN; HOWES; SYNNOTT, 1996).

\subsection{Fisiologia da sensibilidade olfatória}

Embora o olfato humano seja muito rudimentar em comparação com o de outros animais, a função olfativa tem papel fundamental na vida do ser humano. Interfere na percepção do sabor e na palatabilidade, influencia o comportamento sexual e também a função de proteção, pela detecção de substâncias tóxicas. O epitélio olfatório situa-se na parte superior das fossas nasais. Abrange uma área de 2 a $5 \mathrm{~cm}^{2}$, onde aproximadamente 12 milhões de células receptoras estão localizadas. Essa superfície diminui significativamente com a idade. Com relação ao sexo, sabe-se que as mulheres tendem a perceber melhor os odores do que os homens, e também que sofrem variações de percepção olfatória para alguns odores durante a gravidez e o ciclo menstrual (CAMPOS; COSTA, 2002).

Bosy (1997) afirma que os indivíduos possuem diferentes capacidades para perceber o mau odor, e que aspectos individuais interferem no julgamento e avaliação.

O olfato, como a visão, é suscetível à grande adaptação. Na primeira exposição a um cheiro muito forte, a sensação pode ser muito intensa, mas dentro de um minuto, quase não será mais sentido. O epitélio olfativo se fadiga rapidamente (CAMPOS; COSTA, 2002). 
Os receptores olfativos avisam a presença de um odor, mas não ficam bombardeando a pessoa com a sua presença (GUYTON, 1985). Dessa forma, os indivíduos são incapazes de mensurar sua própria halitose (AYERS; COLQUHOUN, 1998; NEIDERS; RAMOS, 1999). Este fato demonstra como a halitose pode afetar socialmente um indivíduo, pois o mesmo pode estar sofrendo desta patologia e, no entanto, não percebê-la. E só tem conhecimento apenas quando alertado por outro, levando a uma situação constrangedora.

Substâncias químicas voláteis também podem entrar em contato com a cavidade nasal pela faringe durante a deglutição, um processo que habilita a olfação retronasal, este caminho permite que os odores orais sejam mais acessíveis para alguns indivíduos e não para outros. A genética, a experiência, o ambiente e a saúde podem afetar a fisiologia e a anatomia dos componentes do sistema olfatório. Existem diferenças quantitativas e qualitativas nas habilidades de percepção olfativa (RAWSON, 1999).

O sistema olfatório tem uma ligação muito próxima com áreas do cérebro que envolvem a emoção (amígdala), o aprendizado e a memória (hipocampo), e talvez por isso que as memórias olfativas evoquem emoções (RAWSON, 1999). O olfato está diretamente relacionado à qualidade de vida, permitindo a interação com o meio em que vivemos pela percepção de seus odores.

\subsection{Conceitos e etiologia da halitose}

A halitose é definida como um odor ofensivo emanado pela boca, ou pelas cavidades nasais, seios da face e faringe. Derivado do latim halitus, que significa respiração, hálito e o sufixo ose que representa anormal ou condição doente, também possui como sinônimos "fetor ex ore" e "fetor oris" (HINE, 1957). 
Halitose é o termo que descreve o odor desagradável que emana da cavidade oral (SANZ; ROLDÁN; HERRERA, 2001).

A etiologia da halitose é localizada na boca, em torno de $90 \%$ dos casos, e pode ser atribuída a: saburra lingual, cárie dental, doença periodontal e infecções orais (SALVADOR; FIGUEIREDO, 2001; MENINGAUD et al., 1999; SANZ; ROLDÁN; HERRERA, 2001; HINE, 1957).

O mau odor é resultante da putrefação realizada pelas bactérias orais dos restos alimentares, descamação celular, saliva e sangue. Em particular por meio da proteólise das proteínas dos peptídeos e aminoácidos, dando origem a compostos voláteis como a metil mercaptana. A intensidade da halitose é associada ao aumento dos níveis intra-orais de compostos sulfurados voláteis (ROSENBERG et al., 1999; SALVADOR; FIGUEIREDO, 2001; WILLIS et al., 1999).

A saburra é um material viscoso, esbranquiçado ou amarelado, que adere ao dorso da língua em maior proporção na região do terço posterior. Pesquisas mostram que a língua representa um importante papel na produção do mau odor bucal (De BOEVER; LOESCHE, 1995; YAEGAKI e SANADA, 1992; GALHARDO, 2002).

Oitenta e duas espécies de bactérias orais podem ser implicadas na produção dos componentes que causam o mau odor, alguns fatores contribuem para o aumento de determinada população, como por exemplo: a diminuição do fluxo salivar, estagnação de saliva, redução do carboidrato como substrato e uma elevação do pH salivar (LOESCHE; De BOEVER, 2003). A microbiota associada à halitose é predominantemente anaeróbia, gramnegativa e utiliza como fonte de nutrientes células descamadas, saliva e fluido gengival oriundos do hospedeiro, assim como também proveniente da dieta (SALVADOR; FIGUEIREDO, 2001; De BOEVER; LOESCHE, 1995). 
A literatura mostra que a maior causa do mau hálito são os microorganismos que produzem compostos sulforados voláteis $\left(\mathrm{H}_{2} \mathrm{~S}\right.$ - sulfeto de hidrogênio e $\mathrm{CH}_{3} \mathrm{SH}$ - metil mercaptana) e que este pode ser controlado pela limpeza da língua e dos dentes (NEIDERS; RAMOS, 1999; De BOEVER; LOESCHE, 1995; WILLIS et al., 1999).

A estagnação de restos alimentares na cavidade bucal pode produzir a halitose, os lugares mais comuns são: o dorso da língua, espaços interdentais e gengivais, áreas onde existem restaurações defeituosas e coroas mal adaptadas. A língua constitui o maior nicho para esta deposição, sua anatomia repleta de papilas contribui para que sejam retidos em sua superfície descamação celular, leucócitos mortos e bactérias (AYERS; COLQUHOUN (1998); SALVADOR; FIGUEIREDO, 2001).

\subsection{Classificação}

Existem diferentes tipos de classificação para a halitose, sendo que cada uma delas é baseada em um aspecto característico, como por exemplo: a classificação pelas causas, da origem, dos aspectos bioquímicos e finalmente, a classificação prática do ponto de vista clínico de Tárzia (2003, p.29), que é a citada a seguir:

\section{Halitose originada na boca}

1) Má higiene bucal

2) Cárie

3) Doença periodontal

4) Impacção alimentar interdental

5) Sangramento gengival

6) Estomatites

7) Feridas cirúrgicas

8) Próteses porosas

9) Cisto dentígero

10) Miíase 
11) Neoplasias

12) Saburra
a) Desidratação
b) Estados febris
c) Vômitos
d) Hipossalivação e ou xerostomia
e) Estresse psicológico
f) Alterações morfológicas da língua
g) Halitose essencial

\section{Halitose originada nas fossas nasais}

1) Halitose por amigdalite

2) Cáseos

3) Halitose por faringite

4) Halitose por sinusite

5) Rinite

6) Halitose por corrimento nasal posterior

7) Halitose por adenóide

8) Alterações das fossas nasais

9) Halitose devida à presença de corpos estranhos

10) Ozena

11) Respiração bucal

\section{Halitose originada na corrente circulatória e que escapa pelos pulmões}

(Odorivetores de origem metabólica)

1) Halitose por alimento de odor carregado

2) Halitose por tabagismo

3) Halitose por medicamentos

4) Halitose devida à absorção de substâncias pela pele e mucosas

5) Halitose por baixa glicemia

a) Halitose por jejum prolongado

b) Grande intervalo entre as refeições

c) Halitose da fome e do regime

d) Exercícios físicos violentos

6) Halitose por alterações intestinais

a) Diarréia 
b) Gastroenterites

c) Constipação intestinal

d) Obstrução intestinal

7) Halitose por alterações hepáticas

8) Halitose por alterações pulmonares

9) Halitose por alterações renais

10) Halitose por alterações estomacais

11) Halitose por diabetes

12) Halitose por trimetilaminúria

\section{Halitoses por doenças raras}

1) Halitose por febre reumática

2) Halitose por desordens neuropsíquicas

3) Halitose por reticuloendotelioses não-lipídicas

4) Macroglobulinemia

5) Herpes simples

6) Hemofilia

7) Doença de von Willenbrand

8) Crioglobulinemia

9) Anemia aplástica

10) Policitemia vera

11) Agranulocitose

12) Leucemia

13) Mononucleose

14) Púrpura trombocitopênica

15) Trombocitemia

16) Sífilis

17) Doença exantemática

18) Hemorragia interna

19) Granulona eosinofílico

20) Doença de Letterer-Siwe

21) Doença de Hand-Schüller-Christian

22) Granulomatose 
Kolbe (2005, informação verbal) ${ }^{8}$ afirma que existe o mito de que a halitose é proveniente do estômago, e que após se alimentar, o hálito melhora, isto de fato ocorre, mas porque existia um quadro de hipoglicemia e também porque, com a mastigação, ocorre o aumento do fluxo salivar.

O hálito conhecido como matutino e aquele das pessoas famintas são temporários, resultantes da estagnação de saliva, células epiteliais e restos alimentares durante o sono, pois existe a diminuição do fluxo salivar e o relaxamento muscular dos músculos da face e da língua (LU, 1982), dificultando dessa forma, a limpeza fisiológica da cavidade oral realizada pelos mesmos (THYLSTRUP, 1988).

A halitose também pode ser induzida por meio de medicamentos que diminuem a salivação e causam a xerostomia. Tais como: antidepressivos, diuréticos e anti-histamínicos, analgésicos, anticolinérgicos, anti-hipertensivos e diversos outros (NEIDERS; RAMOS, 1999).

A saliva desenvolve um papel central na formação do mau odor bucal (KLEINBERG; WESTBAY, 1992; BOSY, 1997; LU, 1982). Ela tem um papel central na formação do mau hálito, pois provê substratos protéicos que são prontamente utilizados pelas bactérias, diminuindo conseqüentemente a quantidade de oxigênio no meio, favorecendo a produção de compostos voláteis odoríferos. Mas ao mesmo tempo é uma fonte de oxigênio, para as bactérias orais.

O pH da saliva também tem importante papel, pois, quando este está neutro ou alcalino, favorece a formação da halitose, e quando está ácido diminui sua formação. O fluxo salivar constante fornece grande quantidade de oxigênio, desfavorecendo assim a degradação de proteínas, por outro lado, se este fluxo tiver diminuído, como durante o sono, quando o

\footnotetext{
${ }^{8}$ Informação fornecida por Ana Kolbe durante o curso: Halitose: um novo portal na odontologia. Realizado no dia 21 de outubro de 2005, durante a 27ª JORP na Faculdade de Odontologia de Ribeirão Preto - USP
} 
metabolismo está mais lento, existe a formação do mau odor - halitose matinal (KLEINBERG; WESTBAY, 1992).

Patologias sistêmicas afetam uma pequena proporção de pessoas com halitose, mas não devem ser desconsideradas, pois podem representar sérias condições médicas, tais como: diabetes, cirrose hepática, hérnia de hiato, refluxo gastroesofágico, úlcera gástrica, faringite, pneumonia e algumas deficiências vitamínicas (AYERS; COLQUHOUN, 1998).

Abaixo na Tabela 1, estão as halitoses por alterações sistêmicas que foram elencadas por Lu (1982) juntamente com o odor característico gerado pela enfermidade.

Tabela 1. Doenças e os odores característicos gerados

\begin{tabular}{ll}
\hline Doenças & Odor característico \\
\hline Diabete melitus & $\begin{array}{l}\text { Acetona, aroma de fruta (não detectados } \\
\text { em pacientes controlados) }\end{array}$ \\
Falência do fígado (estágio terminal) & Adocicado, mofado \\
Febre reumática aguda & Ácido, doce \\
Abscesso pulmonar, tuberculose & Putrefato \\
Discrasias sanguíneas & Semelhante a sangue decomposto \\
Cirrose hepática & Sangue deteriorado \\
Uremia e falência dos rins & Amônia ou urina \\
Desordem gastrointestinal & Muito variado, e a má higiene oral o \\
Febre, desidratação, síndrome de & intensifica \\
Sjögren's & Odor devido à xerostomia associada à \\
Sífilis & má higiene bucal \\
Hemorragia interna & Fétido \\
Doença de Letterer-Siwe & Sangue deteriorado \\
Disenteria, sarampo, escarlatina & Hálito fétido \\
\hline
\end{tabular}

Fonte: LU, D.P. Halitosis: an etiologic classification, a treatment approach, and prevention. Oral Surgery, Oral Medicine and Oral Pathology, v.54, n.5, p.521-526, Nov. 1982. 
Mudanças hormonais que ocorrem durante a ovulação, menstruação, gravidez e menopausa também podem afetar o hálito. A obstrução nasal também pode contribuir para a halitose, pois deixa a boca mais seca impedindo a ação salivar.

Alguns tipos de comida estão fortemente associados com a halitose, como por exemplo: cebola, alho, gordura animal, álcool entre outros (TARZIA, 2003). Hine (1957, p.40) afirma que: "cheiramos o que comemos", ou seja, uma dieta rica em carne animal produz muito mais odor que a de um vegetariano.

A higiene oral deficiente e o tabagismo também contribuem para a formação do mau hálito (LU, 1982).

Infecções orais causam a halitose, tais como: a gengivite ulcerativa necrosante, a pericoronarite e fístulas. Gengivites são manifestações inflamatórias na gengiva marginal, desencadeadas pelo acúmulo de placa bacteriana supragengival, e periodontites se caracterizam por inflamação dos tecidos de sustentação dos dentes, acompanhada de perda de inserção do tecido conjuntivo, a partir da agressão pela placa bacteriana subgengival (OPPERMANN; RÖSING, 1997).

Os níveis de compostos sulforados voláteis e de metil mercaptana são mais altos no ar expelido de pessoas com doenças periodontais do que em pessoas com saúde bucal (YAEGAKI; SANADA, 1992). No entanto, estes compostos ainda podem ser responsáveis pela alteração na síntese de matriz extracelular de proteína, contribuindo para a progressão da doença periodontal (JOHNSON; LANCERO, 1999), ou seja, da mesma forma que os possuidores de doença periodontal possuem grande eliminação de compostos, sabe-se que eles ainda a agravam mais.

De Boever e Loesche (1995) afirmam que as características da superfície lingual interferem na deposição de saburra com conseqüente mau odor, a língua com fissuras profundas facilita esta deposição. 


\subsection{Diagnóstico e epidemiologia}

Antes da década de 1930, a maioria das citações pertinentes à halitose consistia principalmente em pareceres sem estudos ou fatos comprovados que eram perpetuados pela literatura. Durante as décadas de 1940 e 1950, foram realizados diversos estudos utilizando o osmoscópio, um aparelho utilizado na medição de densidades de odor subjetivas e semiquantitativas (TONZETICH, 2003; HINE, 1957).

A direta inalação do mau odor chamada também de avaliação organoléptica é um método seguro para avaliar a presença de halitose, no entanto muito subjetivo, pois indivíduos possuem diferentes percepções de odor (ROSENBERG et al. 1999; AYERS; COLQUHOUN, 1998). Além de evidentemente ser um método desagradável para o pesquisador.

Durante as décadas de 1960 e 1970, as pesquisas concentraram-se principalmente na aplicação de métodos químicos e instrumentais de análises direcionadas para a identificação de compostos primários da halitose. Com base nessa informação, um método altamente sensível e específico de gás cromatográfico (GC) foi adaptado para a medição direta dos compostos sulforados voláteis (CSV) contidos na saliva e no hálito (TONZETICH, 2003).

Posteriormente surgiram os monitores de mercaptana e sulfetos como o halimeter ${ }^{\circledR}$ que é um aparelho passível de ser utilizado em consultórios e outros espaços, capaz de quantificar os odorivetores que compõem o hálito, utilizado por diversos pesquisadores em todo o mundo. O halimeter ${ }^{\circledR}$ (Figura 2) é um monitor que detecta o gás sulfidreto e outros compostos voláteis de enxofre (metilmercaptanas e dimetilsulfeto), capaz de medir alterações no hálito tanto na fase de diagnóstico como na de acompanhamento. Ele foi desenvolvido pela Interscan Corporation com sede nos Estados Unidos (TARZIA, 2003). O halimeter indica valores quantitativos, mas não qualitativos (REINGEWIRTZ et al., 1999). 


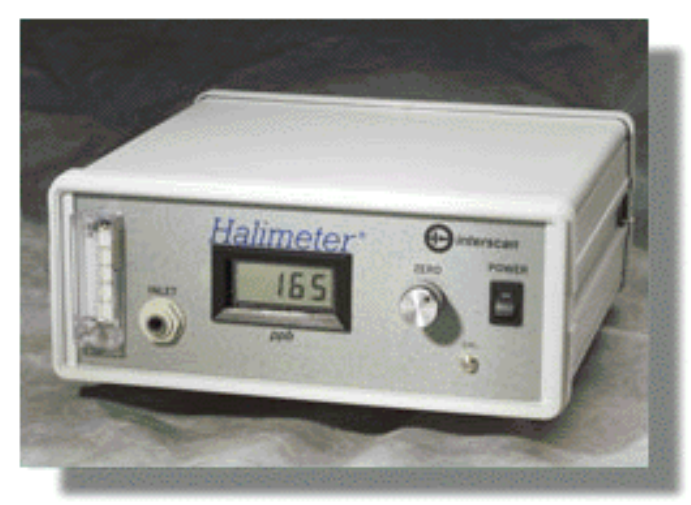

Figura 2. Halimeter

Fonte: INTERSCAN CORPORATION. Disponível em <http:// www. gasdetection. com /halimtr.htm. Acesso em 19 de agosto de 2004.

Yaegaki e Coil (1999a) afirmam que deve-se conhecer a história e os sintomas do paciente em relação à halitose, pois se este apresentar a halitose psicológica, e o profissional apenas examinar a halitose separadamente, sem a compreensão do paciente, existe a possibilidade de o tratamento falhar. É do entendimento de Minayo (1996) que saúde e doença importam tanto por seus efeitos no corpo como pelas suas repercussões no imaginário: ambos são reais em suas conseqüências. Saúde e doença exprimem agora e sempre uma relação que perpassa o corpo individual e social, confrontando com as turbulências do ser humano como ser total.

Uma boa anamnese é fundamental para o correto diagnóstico, devendo-se incluir a queixa principal, a história médica, a história dental, dieta e hábitos, história da halitose e realizar o exame intra-oral (NEIDERS; RAMOS, 1999).

Ayers e Colquhoun (1998) afirmam que 50\% da população sofre de halitose crônica. A halitose tem ocorrência mundial e natureza multifatorial (SALVADOR; FIGUEIREDO, 2001).

Kolbe (2000) mostra que 40\% da população brasileira sofre de mau hálito, 17\% de incidência na faixa de 0 a 12 anos, 41\% na faixa de 12 a 65 anos e $71 \%$ de incidência na faixa acima de 65 anos. Apesar de a incidência de halitose ser maior nos pacientes idosos, os 
aspectos psicológicos, a insegurança e necessidade de aceitação se tornam fatores relevantes para considerar a faixa etária da adolescência neste estudo.

Meningaud et al. (1999) afirmam que o mau hálito é uma importante preocupação da população e fonte para uma indústria muito lucrativa de produtos no mundo, e que entre 50\% a 60\% da população sofre com a halitose. E em relação à idade, dos 5 aos 14 anos a halitose é essencialmente de origem bucal.

A incidência de halitose informada entre pacientes masculinos e femininos é quase a mesma, nenhuma diferença significativa de gênero foi encontrada, no entanto, foi observado que mulheres procuram mais freqüentemente pelo tratamento dentário em relação ao homem (SANZ; ROLDÁN; HERRERA, 2001).

Hine (1957) afirma que os maus odores variam de hora a hora, de dia a dia, mas também de acordo com idade. Crianças jovens normalmente possuem hálito doce, já na idade adulta este se torna mais definido, no entanto, em idade mais avançada se torna mais pesado. Ainda em relação à idade, quando grupos distintos foram comparados, existiu um significante aumento nos valores de CSVs (Compostos Sulforados Voláteis) de acordo com o aumento da idade (SANZ; ROLDÁN; HERRERA, 2001).

Um cheiro é constituído por diferentes odores que, no seu conjunto, o nosso cérebro interpreta como uma unidade. Por exemplo, o cheiro de uma rosa é um conjunto de muitos odores diferentes. Os aparelhos tradicionais que detectam cheiros utilizam um conjunto de sensores em que cada um identifica um odor particular. É depois necessário um computador que analise o conjunto das informações dos sensores e as interprete como sendo um certo cheiro. Apesar de grandes avanços ocorridos na área de detecção de halitose, ainda não existe um método que consiga unir a objetividade do quantitativo com a subjetividade do qualitativo. 


\subsection{Prevenção e tratamento}

Devido à multiplicidade dos fatores etiológicos que podem produzir a halitose, não é possível a indicação de um tratamento único; após o diagnóstico, a remoção das possíveis causas se torna a conduta inicial. Mas como as causas principais da halitose se encontram na boca e estão relacionadas com a placa bacteriana (biofilme), a remoção por meio da escovação, uso do fio dental e raspagem da língua se tornam potentes aliados no combate à halitose.

A prevenção pode e deve ser utilizada, principalmente quando associada à educação em saúde através do autocuidado. Durante a adolescência, o jovem já passa a ter condições de avaliar e de cuidar de sua saúde, minimizando a responsabilidade anterior dos pais.

Quando o adolescente conhece o seu problema e tem mecanismos para preveni-lo ou ainda tratá-lo, este pode ser facilmente resolvido. Tomita (2001) afirma que programas educativos em saúde bucal que aplicam a metodologia participativa têm fundamental importância na mudança de hábitos de higiene bucal em adolescentes, independente da inserção social.

A motivação é tão importante quanto a orientação sobre a higiene que foi dada, pois se o paciente não a valorizar, não irá executá-la. Lascala e Moussalli (1993) ainda ressaltam alguns dentre os objetivos e finalidades da higiene bucal, tais como: eliminação e controle de placa, redução do número de microorganismos sobre os dentes, supra e subgengival, retardar a formação de cálculo, ativar a circulação, impedir a ocorrência da doença gengival e manutenção da saúde bucal.

Como a maioria das halitoses é causada por fatores locais, devemos como primeiro passo eliminar essas causas, através do tratamento periodontal, higiene, restauração de lesões 
cariosas e também manter as próteses bem higienizadas (LU, 1982; NEIDERS; RAMOS, 1999).

Sendo a superfície dorsal da língua e a placa dentária os principais reservatórios de bactérias produtoras de compostos malcheirosos, como estratégia primordial de tratamento, deve-se obter a redução do número de microorganismos por meio da escovação e raspagem da língua visando a remover a saburra (SALVADOR; FIGUEIREDO, 2001).

A remoção mecânica do biofilme lingual pode ser obtida por meio de raspagem ou escovação. A escovação da língua é menos eficaz que os raspadores, que conseguem eliminar grande quantidade de placa, sem a sensação de náusea que a escova às vezes provoca (SEEMANN et al., 2001).

Os limpadores linguais podem ser encontrados no mercado, confeccionados por diferentes materiais como: plástico ou metal flexível (Figura 3). O procedimento para limpeza é simples, basta colocar o arco sobre a parte posterior da superfície lingual, pressionar levemente e puxar para frente, repetidas vezes até limpar toda a extensão. Posteriormente lavar com água corrente (WILKINS, 1994).

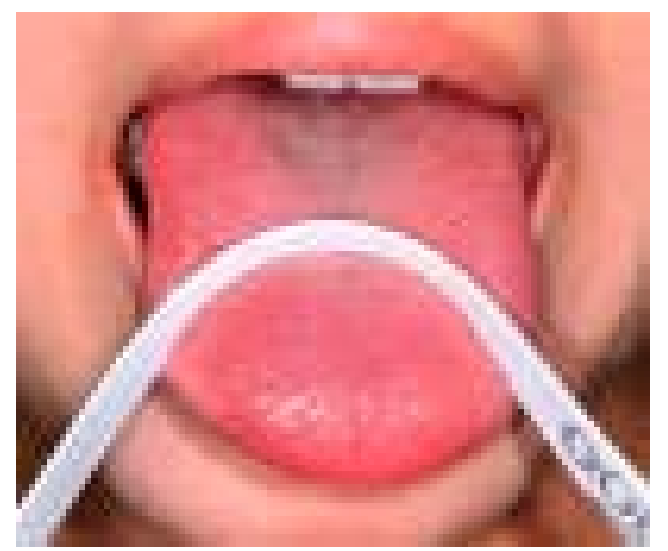

Figura 3. Raspador lingual

Fonte: www.marlysonohara.odo.br/ gengivite.htm 
Se a flora lingual contribui para o mau odor bucal, então o objetivo do tratamento deve ser a utilização de agentes antimicrobianos juntamente com a escovação da língua (LOESCHE, 1999).

No que diz respeito à limpeza dos dentes, a escovação é o meio mecânico mais difundido para o controle não-profissional do biofilme, no entanto mais importante que a freqüência é a qualidade da escovação (BELLINI; ARNENBERG; von der FEHR, 1981). Existem inúmeras técnicas para realizá-la, no entanto, é consenso entre os pesquisadores que a técnica se torna secundária perante a eficiência da limpeza, é freqüente a modificação da técnica pelo paciente com a obtenção de resultados satisfatórios.

Ao mesmo tempo, é importante salientar que muitas técnicas possuem execução complexa e orientação confusa para a grande maioria da população. Apesar disto será apresentada abaixo pequena síntese de algumas técnicas.

Na técnica de Fones, o indivíduo empunha a escova, e com os dentes cerrados faz movimentos circulares na face vestibular de todos os dentes superiores e inferiores, indo do último dente de um hemiarco a outro. Nas faces palatinas ou linguais, os movimentos também são circulares, nas faces oclusais e incisais os movimentos são ântero-posteriores. A técnica de Stillman modificada consiste em colocar a escova com o longo eixo das cerdas lateralmente contra a gengiva e estas são deslizadas de gengival para oclusal ou incisal. Quando as cerdas estiverem junto ao ponto de contato dos dentes, fazem-se movimentos vibratórios, que são repetidos várias vezes para cada grupo de dentes que está sendo escovado (KWON; GUEDES-PINTO, 2003).

Os autores ainda descrevem a técnica de Bass que, durante a escovação, as cerdas são forçadas diretamente no sulco gengival, num ângulo de 45 graus com o eixo do dente. Com as cerdas forçadas ao máximo possível para dentro do sulco, faz-se um movimento curto para frente e para trás, vibratórios, deslocando todo o resíduo existente na área; conforme se 
movimenta a escova, os dentes e gengiva vão sendo limpos. As superfícies oclusais são escovadas, movimentando-se a escova para frente e para trás.

A situação considerada ideal seria a combinação de movimentos corretos que não causem prejuízo periodontal ou dental, com a habilidade de cada paciente em realizar a escovação, reduzindo o biofilme presente na cavidade bucal. É melhor sempre reforçar o movimento que o paciente já executa corretamente, do que ensinar algo novo, orientando-o a sempre dispor de um tempo por dia de forma disciplinada para a higiene bucal, até que esta se torne um hábito.

A freqüência das escovações é determinada pelo horário das refeições, pois deve ser executada após as mesmas, e principalmente antes de dormir. Durante o sono com a diminuição do metabolismo, ocorre menor salivação, e conseqüentemente diminui a proteção natural.

Em relação à limpeza interproximal, o que determina o método a ser utilizado é a anatomia da região (BUISCHI; AXELSSON, 1997). No mercado, existem inúmeros dispositivos disponíveis, tais como: fio dental, fita dental, encerado ou não, composto de fio de nylon (ou multifilamento) ou fio PTFE (monofilamento), palitos triangulares e escovas unitufo. Em relação à forma de uso, basta introduzir o fio e curvá-lo sobre a face do dente executando movimento vestíbulo-lingual e ocluso-apical, mantendo-o sempre intimamente em contato com o dente.

Existe um recurso que facilita a visualização da placa bacteriana, facilitando sua remoção, são chamados de evidenciadores de placa. Podem ser encontrados sob várias formas: pastilhas, solução e tabletes. As soluções e o gel devem ser aplicados com cotonete e as pastilhas mastigadas durante 30 segundos; a seguir deve-se cuspir repetidamente com a finalidade de remover o excesso da substância. Não deve ser deglutido. Podem ser compostos 
de fucsina em solução alcoólica a 2\%, o verde de malaquita, eritrocina dentre outros (LASCALA; MOUSALLI, 1993).

A utilização do evidenciador de placa, além de facilitar a higiene bucal, é um recurso didático muito ilustrativo. A figura abaixo mostra os dentes antes e depois de serem corados pelo evidenciador de placa.

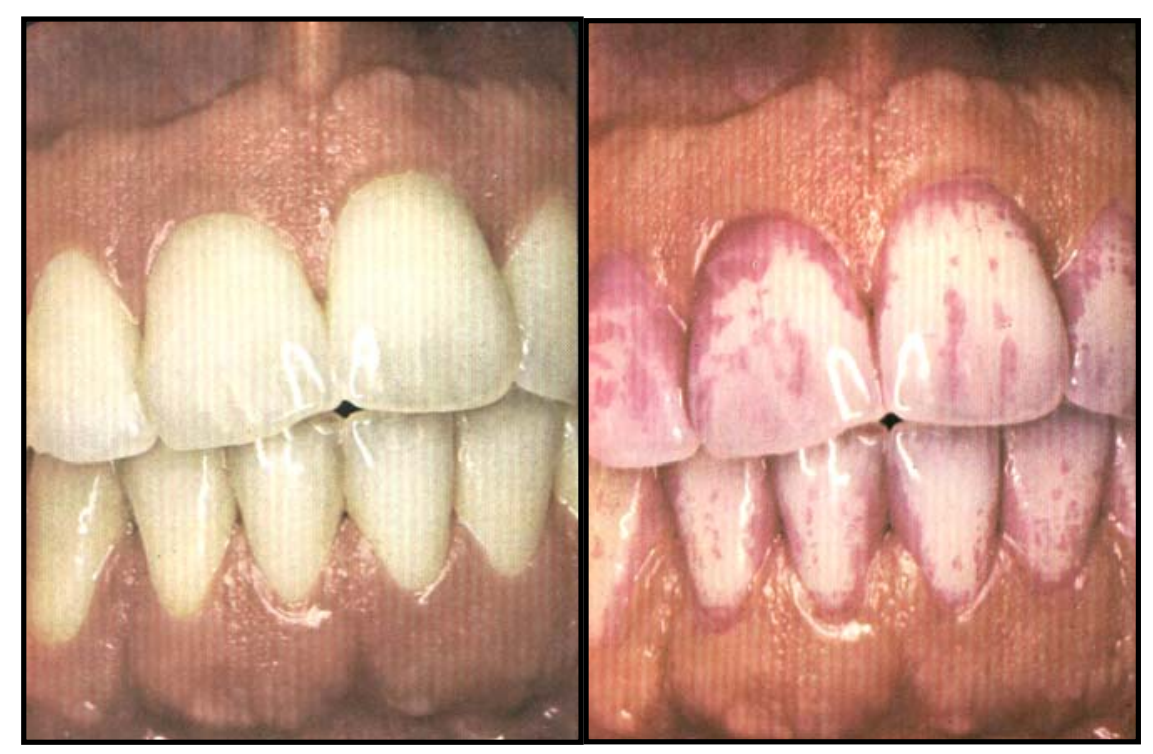

Figura 4. Demonstração de placa bacteriana corada por meio de evidenciadores de placa

Fonte: Guia de orientação ao paciente da Ciba - Biogalênica. p.2.

Segundo Tárzia (2003), o tratamento da halitose pode ser dividido em: curativo, profilático e mascarador. O curativo consiste em realizar a redução mecânica de microorganismos, o profilático em evitar sua proliferação, reduzindo a existência de nichos bacterianos pelo uso de anti-sépticos bucais, e o mascarador no qual é utilizada uma substância que possui odor mais forte que o da halitose.

Alguns métodos mascaradores da halitose são: chicletes, pasta de dentes e enxaguatórios bucais que possuem em sua composição o zinco (MENINGAUD et al., 1999). Reingewirtz et al. (1999) afirmam que gomas de mascar costumam ser utilizadas para 
mascarar temporariamente a halitose, mas após três horas, valores similares de compostos sulforados voláteis já podem ser evidenciados.

No processo mascarante, se utiliza para encobrir um odor degradável uma fragrância e a sensação é que o odor desagradável desapareceu (HINE, 1957). Utilizando este método, o odor original não desaparece, ficando apenas encoberto pela fragrância; pessoas de olfato mais apurado podem detectar o odor original sob a fragrância. Os resultados de uma pesquisa realizada por telefone nos Estados Unidos mostraram que 60\% das mulheres americanas e $50 \%$ dos homens americanos entrevistados recorrem ao uso cosmético de produtos para melhorar o hálito (SANZ; ROLDÁN; HERRERA, 2001).

Visando a uma correta indicação de tratamento e prevenção, uma minuciosa anamnese deve ser realizada. De Boever e Loesche (1995) realizaram um protocolo em seu estudo com algumas etapas, tais como: não beber, fumar, comer, usar balas, chicletes ou enxaguatórios bucais por pelo menos duas horas antes do exame. Não escovar, ou passar fio dental no dia do exame. Avaliar o tipo, formato e aspecto da língua e detectar a presença de cáries, doenças periodontais e restaurações mal adaptadas.

Nos casos de halitose psicológica, recomenda-se o encaminhamento do paciente para um psicólogo, no entanto, antes disto deve-se orientá-lo sobre a halitose, pois talvez conhecendo-a este deixe de temê-la (YAEGAKI; COIL, 1999b). Outro fator importante diz respeito à meticulosa higiene realizada pelo paciente antes de se consultar com um dentista, o que pode fazer com que o profissional subestime a halitose do paciente (NEIDERS; RAMOS, 1999), dessa forma, negligenciando um problema que pode estar afligindo o paciente.

Vários aspectos em relação ao tratamento da halitose devem ser considerados, pois os compostos sulforados voláteis podem representar um fator desagradável nas relações sociais. Assim como, atuar como um agente facilitador, exacerbando os efeitos nocivos de outros fatores participantes nos estágios iniciais da gengivite. E ainda atuar como um agente agressor 
que pode contribuir diretamente para o processo da doença (SALVADOR; FIGUEIREDO, 2001).

Diversas substâncias antimicrobianas auxiliares aos procedimentos mecânicos têm sido utilizadas com a finalidade de exercer um controle químico da placa bacteriana: antisépticos, antibióticos específicos, enzimas, agentes não enzimáticos que alteram o metabolismo bacteriano e substâncias que interferem com a adesão dos microrganismos (MANDEL, 1994). Em relação à halitose, aqueles enxaguatórios que possuem em sua composição o zinco têm a vantagem de que este íon possui grande afinidade pelas substâncias voláteis como o $\mathrm{H}_{2} \mathrm{~S}$ (sulfeto de hidrogênio) e o $\mathrm{CH}_{3} \mathrm{SH}$ (metil mercaptana), convertendo-as em compostos não voláteis compatíveis com o objetivo social (LOESCHE, 1999).

Tárzia (2003) recomenda que, nos casos de redução do fluxo salivar, o paciente pode usar sialogogos que são substâncias que estimulam a salivação. Existem os gustatórios, como por exemplo, alimentos de sabor salgado ou azedo, os sialogogos mecânicos, como o chiclete ou o hiperbolóide que possui consistência superior à do chiclete e ainda os farmacológicos.

Em relação à dieta, a autora afirma que devem-se evitar intervalos superiores a 3 ou 4 horas entre as refeições, ingerir pelo menos dois litros de água por dia e evitar alimentos com odor carregado.

Concluindo, Tárzia (2003) afirma que o tratamento em geral se compõe de três partes: a) orientação de dieta e de higiene bucal, b) tratamento odontológico tradicional e específico e c) encaminhamento ao profissional da área médica, quando necessário. 
3 Objetivos 


\section{OBJETIVOS}

Para atingirmos os propósitos deste estudo temos como objetivos:

3.1 Objetivo geral da pesquisa: Compreender como a halitose é vivenciada entre adolescentes e os reflexos na sua qualidade de vida.

\subsection{Objetivos específicos:}

a) Identificar os significados atribuídos pelos adolescentes à halitose e às pessoas que vivenciam tal problema.

b) Identificar o conhecimento que os adolescentes têm sobre a halitose e quais meios que se utilizam frente a mesma.

c) Analisar os reflexos da halitose entre adolescentes na sua qualidade de vida. 
4 Referencial Teórico 


\section{REFERENCIAL TEÓRICO}

\subsection{Adolescência}

Existem duas formas de se estabelecer a cronologia da adolescência, a primeira é a fixação de datas (cronologia absoluta); e a segunda é a relacionada aos fenômenos da adolescência com outros fatos que ocorrem na sucessão do tempo (cronologia relativa) (CAVALCANTI, 1988).

Para a Organização Mundial de Saúde - OMS (1989), a adolescência é a faixa etária, compreendida entre 10 e 19 anos, e caracteriza-se por importantes e profundas modificações físicas e psicológicas, com repercussões pessoais, familiares e sociais. Enquanto a puberdade pode ser incluída em uma cronologia inequívoca, a adolescência carece de limites cronológicos claros: estende-se com maior ou menor duração, a partir da puberdade, de acordo com o momento que a sociedade atribui e reconhece a geração de adolescentes, ou a um determinado indivíduo adolescente a possibilidade de estabelecer relações sexuais aprovadas e de assumir responsabilidades sociais (FIERRO, 1995).

Sociologicamente, a adolescência termina, quando o grupo social atribui ao indivíduo o status, o papel e a função social do adulto. A partir daí, corta-se o vínculo da dependência familiar. Ao ser dada a liberdade de agir, a sociedade o torna responsável pelos atos que pratica. Sob o ponto de vista psicológico, a adolescência termina, quando o indivíduo atinge a maturidade psicológica ${ }^{9}$ e passa a assumir as responsabilidades e atitudes da vida adulta. Como definição de maturidade psicológica, Cavalcanti (1988) afirma que: é o estado em que o indivíduo domina o seu ambiente, mostra uma certa unidade de personalidade e é capaz de perceber, adequadamente, o mundo e a si mesmo.

\footnotetext{
${ }^{9}$ Maturidade psicológica baseia-se em um critério que é o de se libertar psicologicamente das figuras paternas: é a identificação do próprio Eu, independentemente de suas figuras paternas internalizadas (TIBA, 1986).
} 
A adolescência é a fase de crescimento biopsicossocial que vai da infância à idade adulta. O "crescer" (do lat. adolescere), para que seja uma experiência equilibrada de vida, deve implicar num crescimento solidário biológico, sociocultural e psicológico (CAVALCANTI, 1988).

Segundo Rappaport (1997), o que marca a adolescência do ponto de vista biológico é a puberdade, e a aquisição de um corpo adulto com acesso à expressão da sexualidade e da capacidade reprodutora.

Dá-se o nome de puberdade ao conjunto de modificações físicas que transformam o corpo infantil, durante a segunda década de vida, em um corpo adulto, capacitado para a reprodução. E a adolescência o período psicossociológico que se prolonga por vários anos, caracterizado pela transição entre a infância e a adultícia. A puberdade é um fenômeno universal, já a adolescência adota padrões diferentes de acordo com as culturas. Existem algumas marcas de identidade que podem ser características dos adolescentes ocidentais, tais como: ainda estar no sistema escolar, em algum contexto de aprendizagem profissional ou em busca de um emprego estável; ainda dependerem dos pais, e estar morando com eles; por estarem realizando a transição de um sistema de apego centrado, em parte na família, para um sistema centrado em uma pessoa do outro sexo; por sentirem-se membros de uma cultura de idade (cultura adolescente) que se caracteriza por ter suas próprias modas e hábitos, seu estilo de vida próprio, seus próprios valores; por ter preocupações e inquietudes que não são mais da infância, mas que ainda não coincidem com a dos adultos (PALÁCIOS, 1995).

A maturidade sexual é precedida pelo segundo estirão de crescimento, na puberdade. Do ponto de vista físico, a situação do adolescente não lhe é favorável, pois seu corpo sofre modificações amplas e desordenadas, que fazem com que ele se sinta perdido dentro da própria pele (ARATANGY, 1996). Sendo um período também caracterizado por adaptações a novas estruturas psicológicas e ambientais. 
Aberastury (1981) cita algumas características da adolescência: busca de si mesmo e da identidade, tendência grupal, necessidade de intelectualizar e fantasiar, crises religiosas, deslocalização temporal, atitude social reivindicatória, contradições sucessivas em todas as manifestações da conduta, constantes flutuações do humor e do estado de ânimo, separação progressiva dos pais e evolução sexual desde o auto-erotismo até a heterossexualidade.

A adolescência ainda pode ser caracterizada por meio de alguns aspectos, tais como: a busca da identidade e da independência, maior potencial criativo, necessidade de auto-estima alta, expansão da capacidade de analisar criticamente o mundo, criação do projeto de vida e a necessidade de relacionamento afetivo com outras pessoas, e como conseqüência da maturação sexual, a manifestação genital da sexualidade (DONAS, 1992).

Gauderer (1996) argumenta que o adolescente é o grupo. E que a razão de o adolescente criar e entrar em grupos é para que ocorram o seu crescimento como indivíduo e o seu gradual desenvolvimento, e com isso uma eventual assimilação em grupos maiores, mais amplos e não discriminatórios. Essa coletividade de jovens exerce um efeito educativo na formação e lapidação da personalidade, pois estabelece normas e regras.

O autor ainda complementa que, em um grupo saudável, ocorre uma reavaliação constante e mesmo uma reformulação da personalidade. Essa coletividade de jovens se propõe também a ajudar o adolescente na separação da família, a entender o ambiente familiar e o meio que o cerca. O passo intermediário para chegar à plena individualidade é receber apoio e reconhecimento de um meio mais amplo.

Na turma, o adolescente se sente entre as pessoas que estão em seu mesmo momento existencial, um conjunto de pessoas que estão juntas por opção, porque têm envolvimento afetivo (TIBA, 1986). Seger (1988) sustenta que além de os adolescentes sofrerem grande influência do seu grupo social, pode-se dizer que a aceitação do jovem e suas possibilidades 
de relação são bastante influenciadas pelo aspecto físico, do qual o sorriso e a linguagem são de fundamental importância.

Outra característica de todo grupo é a sensação de segurança que ele fornece, fazendo com que a pessoa assuma uma identidade previamente estabelecida, que ainda não tem. Isto lhe permitirá incorporar, confrontar e aprimorar a sua própria (GAUDERER, 1996).

Os grupos de pares permitem aos adolescentes um certo distanciamento e independência em relação à família a aos adultos em geral. Com a idade, os grupos vão se diferenciando e assumindo uma importância cada vez maior. Eles desempenham um papel significativo na adolescência, exercendo uma influência geralmente muito grande sobre o comportamento, as opiniões e as atitudes dos jovens, sob vários aspectos, particularmente no que concerne a sexualidade. São nos grupos que se estabelecem freqüentemente os laços de amizade e as relações amorosas/sexuais (WEREBE, 1998).

Para Aberatury (1981), o fenômeno grupal adquire uma importância transcendental, já que se transfere ao grupo grande parte da dependência que anteriormente se mantinha com a estrutura familiar e especialmente com os pais. O grupo constitui-se assim a transição necessária no mundo externo para alcançar a individualização adulta. O grupo resulta útil para as dissociações, projeções e identificações que seguem ocorrendo no indivíduo.

As amizades entre parceiros do mesmo sexo ocupam na adolescência um lugar incontestavelmente importante, tanto para os rapazes quanto para as moças. Os amigos oferecem aos adolescentes o que não encontram na família (WEREBE, 1998).

A adolescência é uma fase da vida em que se está mais atento ao próprio corpo, a suas características e desenvolvimento, a suas semelhanças e diferenças em relação ao corpo dos outros (PALÁCIOS, 1995).

Outeiral (1994) argumenta que o adolescente começa a perceber se o seu corpo corresponde ou não ao corpo idealizado para si e também para o grupo de iguais, e via de 
regra, é através da identificação e comparação com os outros adolescentes, que ele começa a ter uma idéia concreta de sua imagem corporal.

Normas sociais atuais enfatizam a importância da imagem pessoal nas relações interpessoais. Neste contexto, o mau odor bucal se torna um importante fator nas relações sociais, podendo originar preocupação, não só em relação ao aspecto de saúde, mas também a alterações psicológicas que conduzem ao isolamento social e pessoal (SANZ; ROLDÁN; HERRERA, 2001). Existem muitas pessoas que não possuem mau hálito, mas exibem um medo excessivo de possuí-lo (NEIDERS; RAMOS, 1999).

Para Osório (1992), a imagem corporal é a forma que o indivíduo representa a condensação de experiências vividas, passadas ou atuais, reais ou fantasiadas, conscientes ou inconscientes. Portanto, de forma sintética, é a imagem que o indivíduo possui de si mesmo. Ainda segundo o autor, a estrutura da imagem corporal é determinada por: a) percepção subjetiva da aparência e habilidade à função; b) fatores psicológicos internalizados; c) fatores sociológicos (a imagem corporal é também função dos papéis que ao corpo são atribuídos pela cultura prevalente num dado momento).

Embora a imagem corporal já esteja estabelecida muito antes desta fase do desenvolvimento, é na adolescência que as preocupações com o próprio físico passam a primeiro plano, pois os efeitos das transformações corporais sobre o julgamento e os sentimentos que o jovem faz de si mesmo são tão importantes quanto as transformações em si (JERSILD, 1971). A percepção do corpo e do mundo se modifica de acordo com os relacionamentos recíprocos entre o corpo e o mundo, incluindo aspectos conscientes e inconscientes (TAVARES, 2003).

Segundo Tiba (1994, p.21), "se os jovens não forem alimentados quanto a sua autoestima, estes poderão ter sérios problemas psicológicos quando adultos". E também, que as aprovações alheias são muito importantes para aumentar a auto-estima dos jovens. 
Rappaport (1997) aponta que, nesta fase, os adolescentes buscam novos referenciais de vida. Se ficarem excessivamente preocupados e ansiosos com as mudanças corporais, poderão se afastar dos amigos e se isolarem.

“No nível psicossocial, uma boca sadia garante a manutenção da boa aparência e da comunicação interpessoal, sendo assim, um fator da maior importância na preservação de auto-estima" (WEYNE, 1997, p.23).

A imagem corporal está ligada à vivência afetiva de nosso próprio corpo e é um elemento real e mutável, passível de se desenvolver, vulnerável aos efeitos deletérios de traumas e doenças (TAVARES, 2003).

Lerman (1942, p.34) afirma que: "...desde los tiempos más remotos se há procurado enaltecer la higiene de la boca como elemento indispensable para la atracción sexual". Dessa forma, a halitose pode ser considerada como um impedimento social (HINE, 1957; LU, 1982), algo que interfere nos relacionamentos pessoais. Afinal, quando beijamos, dividimos o hálito do outro (ACKERMAN, 1992).

Tavares (2003) justifica que a relevância em estudar a imagem corporal está em sua conexão com o desenvolvimento da identidade da pessoa humana e por ser o ponto norteador das relações do homem com o mundo. O desenvolvimento da imagem corporal encontra paralelo no desenvolvimento da identidade do próprio corpo, tendo relação com os aspectos fisiológicos, afetivos e sociais.

A autora ainda complementa que por ser a imagem do nosso próprio corpo, representa uma experiência essencialmente particular, que cada indivíduo vivencia de modo constante, dimensionando a partir dela o sentido de suas ações, de suas percepções e o fluir de seus impulsos. Essa imagem se refere, primordialmente, à identidade do ser humano, do ser corporal. 
Para Sorenson ${ }^{10}$ (1962) apud Aberastury (1981), a identidade é a criação de um sentimento interno da semelhança e continuidade, uma unidade da personalidade sentida pelo indivíduo e reconhecida por outro, que é o “saber quem sou”.

Sendo assim, a identidade corporal e a auto-imagem se estruturam conectadas com as percepções de si mesmo e daquelas resultantes do contato com o mundo. O processo de desenvolvimento da imagem corporal é vinculado a fatores biológicos, culturais, afetivos e ambientais (TAVARES, 2003).

Gauderer (1996) afirma que é fundamental a formação de uma auto-imagem positiva, com conseqüente sensação de auto-estima para que possa ocorrer o relacionamento pessoal e interpessoal de forma adequada e gratificante.

A sexualidade do adolescente encontra sua expressão mais completa no contexto das relações interpessoais. Estas relações são as que envolvem todas as formas de contato erótico, físico ou não, entre dois parceiros, desde troca de olhares, encontros, beijos, carícias até a relação sexual completa. A ativação das necessidades eróticas conduz à aspiração do ser a um complemento indispensável. No decurso do desenvolvimento, dá-se a aprendizagem da reciprocidade, o estabelecimento de uma relação íntima com outra pessoa, fora da família. A intimidade é a necessidade de envolvimento profundo com alguém e influi sobre os padrões e hábitos adolescentes, relacionados com a amizade e interesses românticos (WEREBE, 1998).

Suplicy (1983) caracteriza o beijo como parte da descoberta sexual entre namorados, e que a intimidade do beijo vai aumentando, à medida que os namorados se conhecem.

O beijo é uma demonstração de afeto, um gesto simbólico de afirmação e vínculo com o outro, ele reflete primeiramente uma relação de forças: troca, comércio feliz entre dois

\footnotetext{
${ }^{10}$ SORENSON, R. Youth's need for challenge and place in American society: its implications for adults and adult institutions. Washington: National Committee for Children and Youth Inc, 1962.
} 
seres, quando tudo está bem, mas pode também ser luta, tensão, campo de batalha (CAHEN, 1998).

Ackerman (1992) relata que grande parte da alegria que sentimos em beijar está no fato de acariciar e cheirar o rosto do parceiro. Em várias tribos de países distantes - Bornéu, no rio Gâmbia na África Ocidental, e na Ásia, em Burma e na Índia - a palavra "beijo" na realidade designa cheiro, uma aspiração prolongada dos odores da pessoa amada, de um parente ou amigo. Para alguns povos primitivos, o ar quente que escapava de suas bocas deveria parecer-lhes a incorporação da alma e, portanto, o beijo significaria uma maneira de fundir duas almas.

O namoro, do qual o beijo faz parte, é uma condição de saúde, uma etapa do desenvolvimento, porque as pessoas envolvidas no namoro têm de se deparar primeiro consigo mesmas (auto-imagem corporal, auto-estima, autovalorização), depois com a pessoa complementar e, finalmente, com a família e a sociedade (TIBA, 1986). O autor ainda aborda o relacionamento social-afetivo-sexual como uma etapa muito importante na vida do adolescente, pois resulta de uma série de modificações físicas e transpsíquicas que traz à tona a auto-imagem, a auto-estima e a expectativa de futuro.

Junto com o namoro, durante a adolescência, o jovem começa a experimentar também o desejo de se iniciar sexualmente. No entanto, dependendo da estrutura psicológica e até mesmo do equipamento genético, constitucional e biológico de cada um, muitos jovens, vivem esta fase ao mesmo tempo com fascínio e medo, alternando desejo e culpa. O sexo faz parte da vida e está vinculado ao desenvolvimento da personalidade, das relações interpessoais e da estrutura social. O namoro concretiza uma experiência na qual os desejos adolescentes não podem mais ser satisfeitos pela família (COSTA, 1993). 
Diante de tais conceitos e de todas essas afirmações, acredita-se que o recorte realizado nesta faixa etária se mostra relevante frente ao problema da halitose, que para estes pode se apresentar de maior magnitude em termos de reflexos na qualidade de vida.

\subsection{Qualidade de vida}

A idéia de qualidade de vida não pode ser encarada como algo novo, na história antiga este conceito já aparecia, Aristóteles (384 a.C. - 322 a.C.) preconizava a "boa vida” (sumum bonum) - a vida eudemônica. Esta doutrina visava buscar uma vida feliz, seja em âmbito individual seja coletivo, julgando eticamente positivas todas as ações que conduzissem o homem à felicidade. Nesta concepção, a humanidade florece quando o sujeito é um ser adaptado e atinge uma integração social e psicológica adequada, utilizando todas as potencialidades intelectuais e emocionais (NORDENFELT, 1994).

Na milenar medicina chinesa, a qualidade de vida consiste na inter-relação entre os dois princípios Yin e Yang por meio do equilíbrio entre mutação e permanência, possibilitando atingir a riqueza e a plenitude da vida. O equilíbrio é o conceito fundamental (CAPRA, 1982).

Para Hipócrates (400a.C.), saúde era um estado de equilíbrio entre influências ambientais, modos de vida e vários componentes da natureza humana (VILELA, 1996).

O próprio conceito de saúde passou por muitas transformações, desde a definição da Organização Mundial de Saúde - WHO (1946) na qual saúde é um estado de completo bemestar físico, mental e social e não apenas a ausência de enfermidade, até a de Capra (1982) que acredita ser esta definição um pouco irrealista, pois saúde não é um estado estático, e sim um processo em constante mudança e evolução. É a experiência de bem-estar resultante de 
um equilíbrio dinâmico, envolvendo os aspectos físicos e psicológicos do organismo, assim como suas interações com o meio ambiente natural e social.

Após a Segunda Guerra Mundial, a qualidade de vida passou a ser vinculada à conquista de bens materiais (welfare) e crescimento econômico. No entanto, começaram a surgir reflexões acerca desta afirmação, no sentido de que seria necessária a conquista de outros valores para que se atingisse o bem-estar. O termo "bem-estar" está referido na literatura com dois significados bem distintos: Welfare e Well-being. O primeiro ligado à literatura sociológica, econômica e política sobre o Estado de bem-estar e, em conseqüência diz respeito ao intervencionismo do Estado. O segundo refere-se a um bem-estar de caráter individual e psicológico (CASAS, 1996; TRAVAIN, 2004).

Ou seja, bem-estar social, como igualdade de oportunidades, justiça distributiva e direitos sociais. E qualidade de vida, como bem-estar psicológico, qualidade ambiental, promoção social, participação social e auto-realização.

A expressão qualidade de vida foi introduzida na sociedade contemporânea com uma conotação político-social, tendo suas origens nas ciências humanas e sociais, ligadas à busca de indicadores objetivos capazes de apreender o bem-estar social (SUZUKI, 2002).

Definir qualidade de vida é um desafio, pois segundo Fayers e Machin (2000) trata-se de um constructo multidimensional que tem diferentes significados, para diferentes pessoas, e também possui significados distintos de acordo com a área de aplicação.

Trata-se de uma representação social criada a partir de parâmetros subjetivos (bemestar, felicidade, amor, prazer, realização pessoal), e também objetivos, cujas referências são a satisfação das necessidades básicas e das necessidades criadas pelo grau de desenvolvimento econômico e social de determinada sociedade. É uma aproximação ao grau de satisfação encontrado na vida familiar, amorosa, social e ambiental e na própria estética existencial (MINAYO; HARTZ; BUSS, 2000). 
Os autores ainda afirmam que o termo abrange muitos significados que refletem conhecimentos, experiências e valores de indivíduos e coletividades que a ele se reportam em variadas épocas, espaços e histórias diferentes, sendo, portanto, uma construção social com a marca da relatividade cultural.

Outro aspecto importante a ser considerado é o explicitado por Martin e Stockler (1998) que sugerem que qualidade de vida seja definida em termos da distância entre as expectativas individuais e a realidade (sendo que quanto menor a distância, melhor).

Para Ostenfeld (1994), qualidade de vida é a realização do ser humano, pelo uso pleno de suas potencialidades intelectuais e emocionais. Atualmente a qualidade de vida vem sendo equiparada a uma grande variedade de termos como "satisfação com a vida, bem-estar, saúde, trabalho, felicidade, lazer, auto-estima, valores da vida, necessidades e boa vida” (MEEBERG, 1993; GAÍVA, 1998).

O termo qualidade de vida tem diferentes significados para as pessoas em diversos locais e épocas, variando segundo o contexto em que se vive e se discute, sendo, então, um conceito imbuído de múltiplos pontos de vista (GAÍVA, 1998).

Minayo, Hartz, Buss (2000) discorrem sobre a relatividade do conceito qualidade de vida e fazem referência a três aspectos. O primeiro é o histórico em que o conceito de qualidade de vida varia de acordo com os diferentes momentos históricos de uma mesma sociedade; o segundo é o cultural, relacionado ao fator de que valores e necessidades são construídos e hierarquizados de forma peculiar em cada cultura, caracterizando as suas tradições; o terceiro é o das classes sociais que se refere à forma estratificada como têm se manifestado as classes sociais - os padrões e as concepções de bem-estar nas diferentes camadas sociais, em sociedades com fortes desigualdades. 
Em geral, qualidade de vida relaciona-se com a satisfação das necessidades individuais como crescimento, bem-estar, auto-estima, liberdade e prazer, nos relacionamentos e no trabalho (CHEN; HUNTER, 1996).

Felce e Perry (1996) idealizaram o quadro a seguir (Figura 5) para conceituar qualidade de vida.

\begin{tabular}{|c|c|c|c|c|}
\hline \multicolumn{5}{|c|}{ Avaliação Objetiva das Condições de Vida } \\
\hline \multicolumn{5}{|c|}{ Avaliação Subjetiva da Satisfação Pessoal } \\
\hline $\begin{array}{l}\text { Bem-estar } \\
\text { Físico }\end{array}$ & $\begin{array}{c}\text { Bem-estar } \\
\text { Material }\end{array}$ & $\begin{array}{c}\text { Bem-estar } \\
\text { Social }\end{array}$ & $\begin{array}{c}\text { Desenvolvimento } \\
\text { e atividades }\end{array}$ & $\begin{array}{l}\text { Bem-estar } \\
\text { emocional }\end{array}$ \\
\hline $\begin{array}{c}\text { Saúde } \\
\text { Satisfação } \\
\text { Pessoal } \\
\text { Condicionamento } \\
\text { Físico } \\
\text { Mobilidade }\end{array}$ & $\begin{array}{c}\text { Finanças e } \\
\text { Renda } \\
\text { Qualidade } \\
\text { da } \\
\text { moradia: } \\
\text { privacidade, } \\
\text { vizinhança, } \\
\text { posses e } \\
\text { alimentação. } \\
\text { Transporte } \\
\text { Segurança }\end{array}$ & $\begin{array}{l}\text { Relações pessoais, } \\
\text { vida doméstica, } \\
\text { família e parentes, } \\
\text { amigos e vida } \\
\text { social } \\
\text { Envolvimento na } \\
\text { comunidade, } \\
\text { atividades, } \\
\text { aceitação e apoio }\end{array}$ & $\begin{array}{c}\text { Competência, } \\
\text { independência, } \\
\text { escolha e } \\
\text { controle } \\
\text { Produtividade e } \\
\text { atividade, } \\
\text { trabalho, serviço } \\
\text { doméstico, } \\
\text { educação, leitura } \\
\text { e hobby }\end{array}$ & $\begin{array}{c}\text { Pensamento } \\
\text { positivo, } \\
\text { estresse, saúde } \\
\text { mental, amor } \\
\text { próprio, status } \\
\text { e respeito, fé e } \\
\text { convicção e } \\
\text { sexualidade }\end{array}$ \\
\hline $\begin{array}{l}1 \\
1 \\
1\end{array}$ & $\begin{array}{l}1 \\
1 \\
1\end{array}$ & 1 & 1 & $\begin{array}{l}1 \\
1 \\
1\end{array}$ \\
\hline \multicolumn{5}{|c|}{ Valores pessoais } \\
\hline 1 & $t$ & I & $\begin{array}{r}t \\
t\end{array}$ & $\begin{array}{l}1 \\
t\end{array}$ \\
\hline & & Qualidade de vida & & \\
\hline
\end{tabular}

Figura 5. Conceituação de qualidade de vida

Fonte: FELCE, D.; PERRY, J. Exploring current conceptions of quality of life. In: RENWICK, R.; BROWN, I.; NAGLER, M. Quality of life in health promotion and rehabilitation: conceptual approaches, issues, and applications. California: Sage publications, 1996. p. 51-62. 
Pela definição da qualidade de vida como a percepção do indivíduo de sua posição na vida, no contexto da cultura e sistema de valores nos quais ele vive, e também em relação aos seus objetivos, expectativas, padrões e preocupações (WHO, 1995), torna-se relevante avaliar se a plenitude desta qualidade de vida será influenciada, pois se o indivíduo apresentar restrições físicas e psicológicas estas podem interferir sobre aspectos da fala, convívio social e auto-estima (SHEIHAM et al., 2001).

Maslow (1970) desenvolveu uma teoria de motivação centrada no conceito de autorealização, a Pirâmide de Maslow, que hierarquiza as necessidades humanas por ordem crescente.

As necessidades descritas pelo autor são as seguintes:

Necessidades Fisiológicas: representam as necessidades instintivas de sobrevivência tais como a alimentação, o descanso, a proteção contra elementos naturais, etc.

Necessidades de Segurança: surgem quando estão satisfeitas as necessidades fisiológicas e representam as necessidades de estabilidade e segurança no emprego e de proteção contra privações, perigos e ameaças.

Necessidades Sociais: Incluem as necessidades de participação, de dar e receber afeto, amizade e amor. Surgem após a satisfação das necessidades primárias e a sua nãosatisfação pode levar à falta de adaptação social e à auto-exclusão.

Necessidades de Auto-estima: correspondem às necessidades de respeito próprios (autoconfiança, aprovação e consideração social, prestígio profissional, dependência e autonomia). A não-satisfação destas necessidades pode conduzir a sentimentos de inferioridade e ao desânimo.

Necessidades de Auto-realização: surgem após a satisfação de todas as restantes necessidades, representando as necessidades humanas mais elevadas tais como a 
necessidade de conseguir o desenvolvimento pessoal pela utilização de todas as suas capacidades e potencialidades.

Para ele, as necessidades dos seres humanos obedecem a uma hierarquia, ou seja, uma escala de valores a serem transpostos. Isto significa que no momento em que o indivíduo realiza uma necessidade, surge outra em seu lugar, exigindo sempre que as pessoas busquem meios para satisfazê-la. E que, se o indivíduo se contentar com menos do que pode ser, será sempre infeliz.

Dessa forma, qualidade de vida consiste nas relações que a pessoa estabelece consigo mesmo e com o mundo circundante.

Problemas de comportamento em adolescentes são mais comuns de acontecer quando as oportunidades de satisfação diária estão ausentes. E a alienação e os comportamentos de risco aparecem mais quando as oportunidades não são vistas como disponíveis para satisfação futura e felicidade (RAPHAEL, 1996).

Considerando essas afirmações, é relevante avaliar se a halitose pode afetar a qualidade de vida dos adolescentes, pois esta pode se tornar um fator de influência no bemestar social e emocional que são pilares para a qualidade de vida.

\subsection{Pressupostos}

Os pressupostos deste estudo delinearam o quadro teórico que foi embasado nos conceitos sobre a adolescência e qualidade de vida.

Acreditamos que a halitose prejudica os relacionamentos interpessoais dos adolescentes impondo uma barreira entre este e a turma, objetivo tão almejado neste período. 
Assim como entendemos que pode comprometer a vivência da sexualidade na adolescência, considerando a proximidade física de um relacionamento, o beijo e os contatos sexuais.

E que o desconhecimento desta patologia e de como preveni-la, permite sua ocorrência.

Diante de tudo que foi exposto, consideramos que a halitose pode limitar a qualidade de vida dos adolescentes, em vários aspectos. Principalmente em relação ao bem-estar social e emocional, que são pilares para a qualidade de vida.

A situação de halitose poderia ser prevenida, tratada e principalmente, orientada por meio de ações educativas. 
5 Trajetória Metodológica 


\section{TRAJETÓRIA METODOLÓGICA}

\subsection{Caracterização da Pesquisa}

O método científico permite que a realidade social seja reconstruída como um objeto de conhecimento, por meio de um processo de categorização que une dialeticamente o teórico e o empírico (MINAYO, 2001).

O presente estudo tem como característica ser uma pesquisa estratégica que visa a lançar luz sobre aspectos da realidade. A escolha pela metodologia qualitativa se deu pelo fato de que o objeto estudado tem características das ciências sociais.

O objeto das ciências sociais é histórico, está em transição, admite sempre aperfeiçoamento e superação, possui também identidade entre o sujeito e o objeto, pois quando estudamos a sociedade estudamos a nós mesmos (MINAYO, 2001). Demo (1987, p.15) lembra que “o fenômeno humano possui componentes irredutíveis às características da realidade exata e natural”. Existe também uma relação entre sujeito e objeto, pois os dois são da mesma natureza (Levi-Strauss ${ }^{11}$ apud MINAYO, 1996, p.21).

A pesquisa qualitativa permite estudar os atores sociais dentro de seu contexto, conhecendo também aspectos de valor, crenças, motivos, emoções e significados (MINAYO, 1996; GOLDENBERG, 2002). Existe a possibilidade de aprofundar a compreensão de um grupo social e devido à particularidade dos fatos sociais, torna-se necessário que cada caso concreto seja compreendido em sua singularidade. Enquanto os métodos quantitativos supõem uma população de objetos comparáveis, os métodos qualitativos enfatizam as particularidades de um fenômeno em termos de seu significado para o grupo pesquisado (GOLDENBERG, 2002).

\footnotetext{
11 LEVI-STRAUSS, C. Aula Inaugural: desvendando máscaras sociais. Rio de Janeiro: Ed. Francisco Alves, 1975, p. 211-244.
} 
E a proposta é de se estudar o objeto em profundidade e não em extensão, visando a compreender a complexidade em sua particularidade, enquanto os métodos quantitativos abstraem por generalização, os qualitativos generalizam por abstração. Buscando significados, valores, motivos, atitudes e crenças que não têm como serem mensurados.

O método qualitativo difere do quantitativo à medida que não emprega um instrumental estatístico como base do processo de análise de um problema. Não pretende numerar ou medir unidades ou categorias homogêneas e sim compreender processos dinâmicos vividos por grupos sociais. (RICHARDSON, 1999, p.79)

O autor ainda afirma que ele pode ser caracterizado como a tentativa de uma compreensão detalhada dos significados e características situacionais apresentadas pelos entrevistados, em lugar da produção de medidas quantitativas de característica de comportamento.

Minayo (1996) esclarece que o rigor matemático pode ser uma meta e vir junto a outras formas de validação, mas nunca substituir a percepção de conteúdos latentes e intuições não passíveis de quantificação. A abordagem qualitativa aprofunda-se no mundo dos significados das ações e relações humanas, um lado não perceptível e não captável em equações, médias e estatísticas. O objeto saúde oferece um nível possível de ser quantificado, mas o ultrapassa quando se trata de compreender dimensões profundas e significativas que não conseguem ser aprisionadas em variáveis. Triviños (1987) afirma que a preocupação essencial da abordagem qualitativa é o significado. 


\subsection{Campo de estudo}

Campo de pesquisa é o recorte que o pesquisador faz em termos de espaço, representando a realidade empírica a ser estudada, a partir das concepções teóricas que fundamentam o objeto de investigação (MINAYO, 2001).

Ribeirão Preto situa-se no nordeste do Estado de São Paulo, a 313 km da capital. Os limites da cidade são dados pelos seguintes municípios: ao sul, Guatapará; a sudeste, Cravinhos; ao norte, Jardinópolis; a leste, Serrana: a oeste, Dumont; a noroeste, Sertãozinho; e a nordeste, Brodowski. Apresenta clima tropical com verão chuvoso e inverno seco, a temperatura média no inverno é de $19^{\circ} \mathrm{C}$ e no verão de $25^{\circ} \mathrm{C}$. A precipitação pluviométrica média é de 1.426,80 mm de chuva (total ano) e a umidade relativa do ar: 71\% média anual (CODERP, 2006).

Na tabela abaixo, temos o perfil municipal de Ribeirão Preto.

Tabela 2. Perfil do Município de Ribeirão Preto, 2006.

\begin{tabular}{lcccc}
\hline Território e População & Ano & Município & Reg. Gov. & Estado \\
\hline Área (Em km²) & 2005 & 642 & 9.348 & 248.600 \\
População & 2005 & 543.885 & 1.147 .195 & 39.949 .487 \\
Densidade Demográfica (Habitantes/km²) & 2005 & 847,17 & 122,72 & 160,70 \\
Taxa Geométrica de Crescimento Anual da & 2005 & 1,53 & 1,62 & 1,56 \\
População - 2000/2005 (Em \% a.a.) & 2005 & 99,66 & 97,06 & 93,65 \\
Grau de Urbanização (Em \%) & 2005 & 49,16 & 43,18 & 39,17 \\
Índice de Envelhecimento (Em \%) & 2005 & 22,10 & 23,59 & 24,43 \\
População com Menos de 15 Anos (Em \%) & 2005 & 10,86 & 10,19 & 9,57 \\
População com Mais de 60 Anos (Em \%) & 2005 & 92,99 & 97,01 & 95,85 \\
Razão de Sexos & & &
\end{tabular}

Fonte: http://www.seade.gov.br/produtos/perfil/perfil.php. Disponível em: www.coderp.com.br / Acesso em 26 de abril de 2006.

Com relação à adolescência no município de Ribeirão Preto, a faixa etária que compreende as idades de 10 a 19 anos representava em 2000 - 18,69\% do total da população (CODERP, 2006). 
A Divisão Odontológica da Secretaria Municipal da Saúde de Ribeirão Preto está estruturada para dar ao munícipe condições de realizar seu tratamento dentário da seguinte maneira (RIBEIRÃO PRETO, 2006):

Atendimento básico ao escolar: É realizado em 59 escolas da rede oficial de ensino, onde o escolar pode contar com atendimento emergencial, e atendimento básico curativopreventivo. Sendo 14 EMEIS, 18 Escolas Municipais e 25 Escolas Estaduais.

Atendimento básico em unidades: Atendendo emergências e atendimento básico em odontologia, profilaxia, restaurações de amálgama e resina, exodontias, aplicação tópica de flúor, selantes, etc. O munícipe deve pertencer à área de abrangência.

Atendimentos especializados: NGA - atendimento a pacientes portadores de HIV e referenciamento secundário (CTO - Centro de Triagem Odontológica), PRODAF atendimento a crianças portadoras de deficiência auditiva e fissura palatal, COP - atendimento de crianças de 0 à 4 anos incompletos e ENDODONTIA - UBDS Central.

Realização do pronto-atendimento emergencial: na UBDS Central funcionando 24 horas.

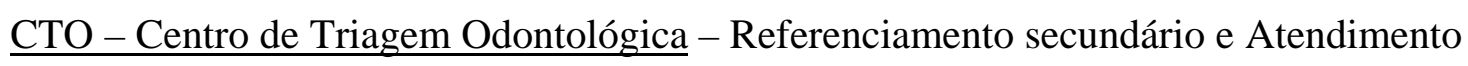
a pacientes com HIV. Funciona no Núcleo de Gestão Assistencial - (Ambulatório Regional de Especialidades).

Existem ainda os programas: Levantamento Epidemiológico de Cárie Dentária, Câncer de Boca, Odontologia Para Bebês, Programa Meu Bem Querer (atendimento odontológico prioritário à gestante), Programa de Procedimentos Coletivos em Odontologia, Projeto Segunda Escola, Auto-Exame da Boca - Conheça sua Boca (RIBEIRÃO PRETO, 2006). 
A Figura 6 a seguir representa a média de anos de estudos da população de 15 a 64 anos de Ribeirão Preto/SP.

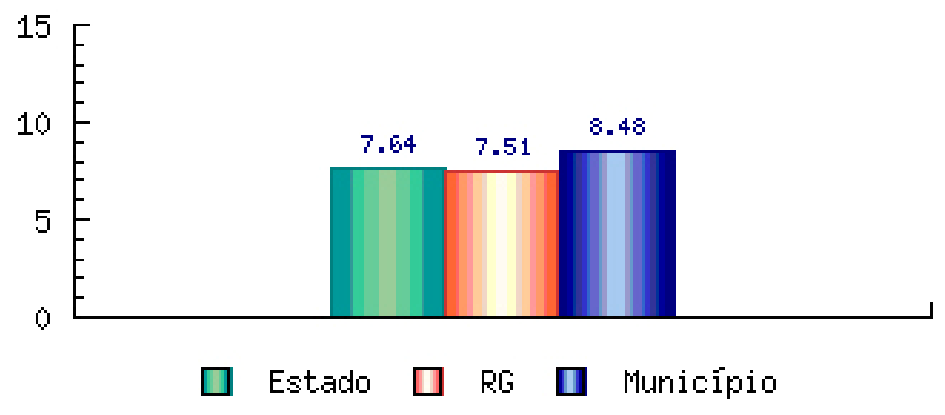

Figura 6. Educação - média de anos de estudos da população de 15 a 64 anos. Estado de São Paulo, Região de Governo de Ribeirão Preto e Município de Ribeirão Preto, 2000.

Fonte: Disponível em: http://www.seade.gov.br/produtos/perfil/perfil.php. Acesso em 26 de abril de 2006.

Realizamos este estudo no município de Ribeirão Preto em escolas da rede pública e privada de ensino. A opção por realizar este estudo, a partir das escolas, se deu, por entendermos que elas espelham, em certos aspectos, a sociedade na qual se inserem, reproduzindo em parte sua estrutura.

Segundo Rodrigues (1996), a escola não é uma instituição neutra frente à realidade social, sofre influências e influencia aquilo que acontece ao seu redor. Em outras palavras, a escola está inserida numa certa realidade da qual sofre e exerce influência. Ela é um local em que se reproduzem os interesses, os valores, a cultura e a ideologia.

Pérez Gomes (2001) afirma que a cultura social dominante no contexto político e econômico a qual pertence a escola impregna inevitavelmente os intercâmbios humanos que se produzem nela.

Realizamos um levantamento junto à Diretoria de Ensino - Região Ribeirão Preto para a obtenção dos dados necessários à realização deste estudo, ou seja, o Cadastro dos Estabelecimentos do Ensino Regular e as relações das escolas com os respectivos endereços. 
Tendo em vista a impossibilidade de avaliar todas as escolas, foi realizado sorteio, conscientes de que a escola sorteada representa o estrato social a qual está classificada, diante da relativa homogeneidade de cada uma delas.

Após serem identificadas e classificadas de acordo com o critério de estratificação social, usado como referencial neste estudo, sorteamos 1 (uma) escola representante de cada estrato social.

As escolas sorteadas foram:

Baixo - EMEF. Prof. José Rodini Luiz (setor - 407), ou seja, setor Leste, subsetor 7.

Médio-baixo - EMEF. Vereador José Delibo (setor - 405), ou seja, setor Leste, subsetor 5 .

Médio-alto - EE. Prof. Sebastião Fernandes Palma (setor - 401), ou seja, Setor Leste, subsetor 1.

Alto - Particular. Vita et Pax (setor 510) - setor Oeste, subsetor 10.

\subsection{Sujeitos do estudo}

Participaram deste estudo 43 adolescentes selecionados a partir de sorteio por intermédio da lista de chamada, com idades entre 11 e 15 anos. Sendo 22 meninas e 21 meninos. Divididos entre os estratos: alto, médio-alto, médio-baixo e baixo.

Esse grupo de alunos foi considerado ideal, considerando-se a exaustão, a homogeneidade, a pertinência aos objetivos do trabalho e a representatividade das falas nas quatro escolas sorteadas para este estudo. 
Minayo (1996) afirma que uma boa amostragem é aquela que possibilita abranger a totalidade do problema a ser investigado em suas múltiplas dimensões. A representatividade numérica não é a preocupação da pesquisa qualitativa e sim o aprofundamento da compreensão. Portanto, cada indivíduo é uma síntese individualizada e ativa de uma sociedade, uma reapropriação singular do universo social e histórico que o envolve, a quantidade é, então, substituída pela intensidade e pela imersão profunda (GOLDENBERG, 2002).

Nesta pesquisa, foi utilizado o conceito de estrato social, entendido como a distribuição desigual de bens e serviços, direitos e obrigações, poder e prestígio. Todos são atributos de posições sociais e não de indivíduos. Quando se diz que uma sociedade é estratificada, referem-se a uma característica da estrutura dessa sociedade, e querem dizer que a sociedade mostra cotas ou descontinuidades significantes na distribuição de um ou vários dos atributos acima mencionados, de cujo resultado se formam coletividades ou grupos a que chamamos de estratos (LITTLEJOHN, 1976).

Segundo Tumin (1970), estrato social é a disposição de qualquer grupo ou sociedade numa hierarquia de posições desiguais com relação ao poder, propriedade, valorização social e satisfação psicológica, estes conceitos não são objetos concretos e sim aspectos abstratos. O poder refere-se à capacidade da pessoa para conseguir seus objetivos na vida, mesmo diante de oposição. A propriedade pode ser definida como direitos a bens e serviços. A valorização refere-se a um julgamento societário de que uma posição ou um status são mais prestigiosos ou honrosos do que outros. A satisfação psicológica inclui todas as fontes de prazer e contentamento que não sejam classificáveis como propriedade, poder ou valorização.

O autor ainda esclarece que a palavra social é um qualificativo importante, pois os estratos consistem de status socialmente definidos que recebem cotas socialmente determinadas, de poder, propriedade e prestígio. 
Neste estudo, foram utilizados os critérios de estratificação social estabelecidos por Ribeiro (1998).

Para a classificação dos bairros do município de Ribeirão Preto, a autora estabeleceu divisões econômicas entre as diversas áreas da cidade, utilizando dados do Instituto Brasileiro de Geografia e Estatística (IBGE), referente à localização dos domicílios e à distribuição de renda por chefes de família residentes.

O município foi dividido em setores e subsetores, baseado no decreto $\mathrm{n}^{\circ} 333$ de 26 de dezembro de 1983 da Prefeitura Municipal de Ribeirão Preto (Anexos G e H). O objetivo desta divisão prendeu-se ao fato de que se pudesse, com maior precisão, realizar levantamentos de densidade demográfica, definição de zonas residenciais, comerciais e industriais, ou seja, para obter com maior clareza dados indispensáveis ao planejamento de atividades relacionadas à saúde, à educação, ao saneamento, abastecimento, transporte e outros.

Entendemos por setor a divisão do distrito-sede em cinco áreas distintas, delimitadas por acidentes geográficos, barreiras físicas e vias de tráfego pesado, localizadas de acordo com os quadrantes: Norte(N), Leste(L), Sul(S), Oeste(O) e Central(C).

O setor Norte possui 19 subsetores, o Leste, 13 subsetores, o Sul, 10 subsetores, o Oeste, 16 subsetores, e por fim o setor Centro que não possui subsetores.

Dados encontrados por Ribeiro (1998, p.29):

a) Bairros de estrato socioeconômico baixo foram considerados aqueles que continham $70 \%$ ou mais da população de chefes de família com rendimento inferior a 5 salários mínimos;

b) Bairros de estrato socioeconômico médio-baixo continham entre $45 \%$ e 70\% dos chefes de família com salários inferiores a 5 salários mínimos; 
c) Bairros de estrato socioeconômico médio-alto eram aqueles que continham 20 a 45\% dos chefes de família com menos de 5 salários mínimos;

d) Bairros de estrato socioeconômico alto - quando a porcentagem de chefes de família com rendimento inferior a 5 salários mínimos foi menor que 20\%. 
Os dados originaram o mapa abaixo:

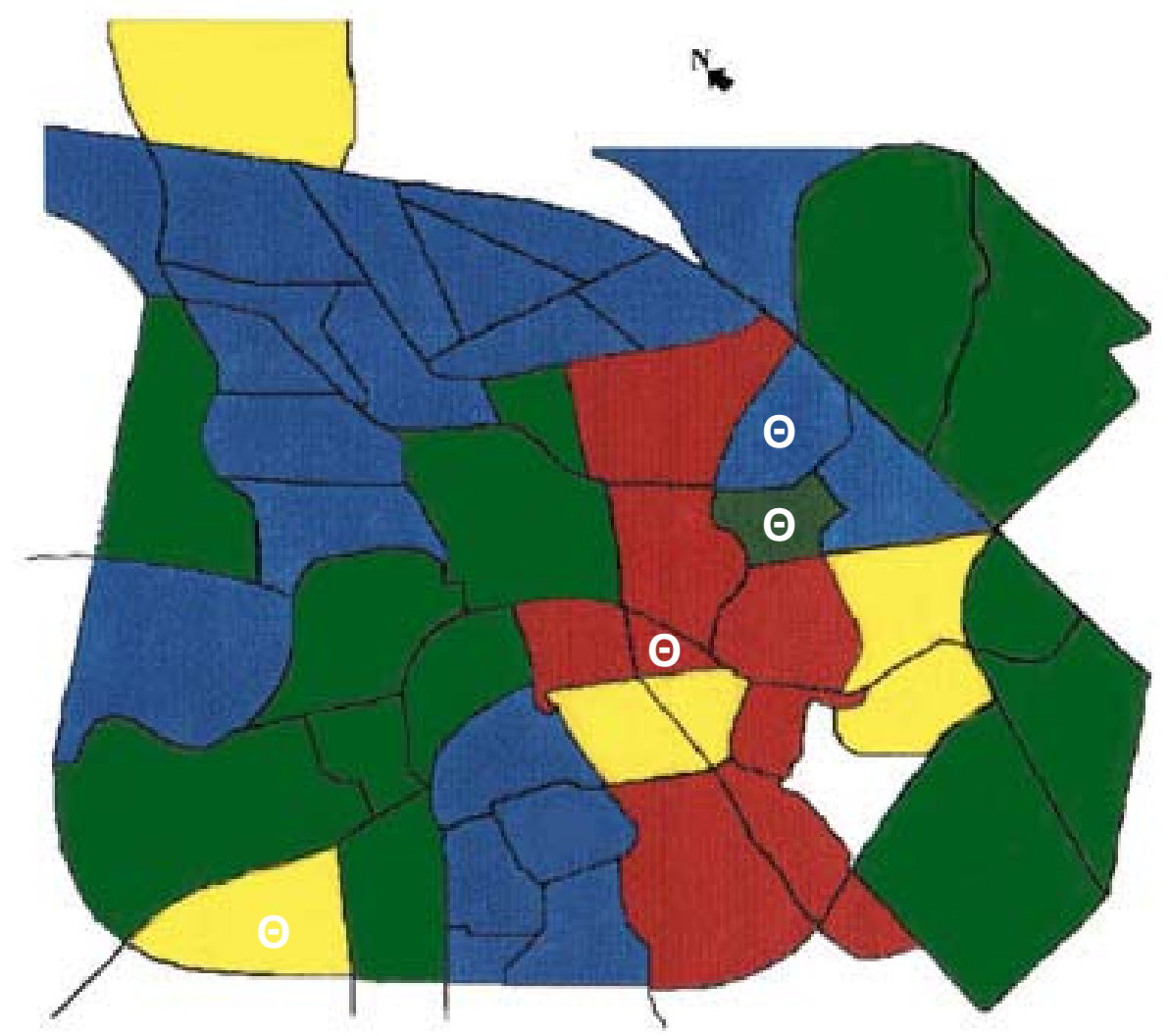

Estrato Baixo

Estrato Médio-Baixo

Estrato Médio-Alto

Estrato Alto

Figura 7. Mapa com a estratificação social em que as escolas sorteadas estão sinalizadas por meio de círculos brancos. 


\subsection{Instrumentos para coleta de dados}

Neste estudo foi utilizado como instrumento de coleta de dados a entrevista semiestruturada individual, pois o objeto trata de um assunto de sensibilidade particular que pode provocar ansiedade, se trabalhado em grupo.

O que torna a entrevista um instrumento privilegiado de coleta de informações para as ciências sociais é a possibilidade da fala ser reveladora de condições estruturais, de sistemas de valores, normas e símbolos e ao mesmo tempo ter a magia de transmitir, por intermédio de um porta-voz, as representações de grupos determinados, em condições históricas, socioeconômicas e culturais específicas (MINAYO, 1996).

A entrevista partiu de um roteiro que difere do sentido tradicional de questionário. O roteiro que está abaixo conteve poucas questões, foi apenas um guia. E sua finalidade principal: "facilitar a abertura de ampliação e de aprofundamento da comunicação" (MINAYO, 1996, p.99). As questões foram elaboradas de forma a enumerar de forma mais abrangente possível os objetivos do estudo.

\section{Questões norteadoras utilizadas na entrevista semi-estruturada}

1)Você sabe o que é mau hálito?

2) Conhece alguém que tem mau hálito? O que você acha dessa pessoa?

3) Sabe de alguma história em que o mau hálito possa ter interferido nos relacionamentos (ficar/namoro) de alguém? Não precisa citar nomes.

4) O que mais te incomoda na boca do outro?

5) O que você acha que pode causar o mau hálito?

6) Como você cuida de sua saúde bucal? 
Essas questões não obedeceram a uma seqüência rigorosa para todos os entrevistados. Cada um deles determinou seu próprio ritmo, tendo a liberdade de questionar suas dúvidas.

Após o sorteio das escolas, marcamos entrevista com as diretoras das escolas visando a esclarecer os objetivos do nosso estudo, a duração e o modo de realização, assim como obter as declarações de autorização para realização da pesquisa.

Pela lista de chamada foram sorteados os alunos e entregue os termos de consentimento livre e esclarecido. Após a conclusão desta etapa, foram agendadas com os coordenadores das escolas as entrevistas.

Foi solicitada uma sala com uma mesa e duas cadeiras, onde tivesse, se possível, ausência de barulho para não atrapalhar as gravações. As entrevistas foram realizadas durante o horário escolar, cuidando-se para não interferir no rendimento escolar do aluno.

Procuramos propiciar um clima favorável de descontração com uma conversa inicial, por meio da qual os entrevistados receberam explicações dos objetivos da pesquisa, assim como, foi dada a liberdade para que esclarecessem quaisquer dúvidas relacionadas à odontologia. Permitindo dessa forma que houvesse uma troca simbiótica, entre os sujeitos do estudo e o pesquisador.

Para registrar as falas, utilizamos um gravador e anotações. Importante salientar que era perguntado ao adolescente se este permitia que a entrevista fosse gravada.

Durante a entrevista, utilizamos um instrumento complementar, com a finalidade de ampliar a desenvoltura dos adolescentes para lidar com o assunto pesquisado. Entregamos um papel que continha duas colunas predefinidas, com as seguintes palavras no topo da folha: pessoa com mau hálito e pessoa sem mau hálito (Anexo I). E os sujeitos da pesquisa foram orientados para escrever o que lhes viesse à cabeça livremente sobre essas duas situações.

Com a finalidade de identificar as entrevistas, foi utilizada a primeira letra do nome do adolescente, sexo, seguido de sua idade e estrato social pertencente. 


\subsection{Aspectos éticos da pesquisa}

Com o objetivo de salvaguardar a dignidade, os direitos, a segurança e o bem-estar dos sujeitos de pesquisa, foram tomadas todas as precauções necessárias.

A proposta do presente estudo foi encaminhada para a apreciação do Comitê de Ética em Pesquisa da Escola de Enfermagem de Ribeirão Preto da Universidade de São Paulo, conforme recomenda a Resolução n. 196, de 10 de outubro de 1996, que regulamenta o desenvolvimento de pesquisas envolvendo seres humanos, e aprovada sob o protocolo n. 0529/2005 (anexo B).

Um Termo de Consentimento Livre e Esclarecido (anexo A) foi enviado para os pais ou responsáveis dos adolescentes participantes do estudo para conhecimento e devidamente assinado para que seus filhos pudessem participar da pesquisa.

Também foi elaborado um documento que foi entregue aos diretores das escolas participantes do estudo, visando à autorização para a realização da pesquisa no estabelecimento (Anexos C, D, E e F).

\subsection{Análise dos dados}

Para interpretar os dados e melhor compreender os significados, utilizou-se a técnica de análise de conteúdo, na modalidade de análise temática. A análise de conteúdo é definida por Bardin (1979) como um conjunto de técnicas de análise das comunicações que utiliza procedimentos sistemáticos e objetivos de descrição do conteúdo das mensagens.

Minayo (1996) afirma que uma das funções da análise de conteúdo é descobrir o que está por trás dos conteúdos manifestos, indo além das aparências. Estudar as comunicações entre os homens, colocando ênfase no conteúdo das mensagens (TRIVIÑOS, 1987). 
Bardin (1979) ainda define análise de conteúdo como uma análise de significados, em outras palavras o que se procura estabelecer é uma correspondência entre as estruturas semânticas ou lingüísticas e as estruturas psicológicas ou sociológicas dos enunciados. A análise de conteúdo é um conjunto de instrumentos metodológicos que se aplica em discursos, é uma hermenêutica controlada, baseada na dedução por inferência. Visa a obter, por procedimentos, sistemáticos e objetivos de descrição do conteúdo das mensagens, indicadores que permitam a inferência de conhecimentos relativos às condições de produção/recepção destas mensagens.

\begin{abstract}
George $^{12}$ apud BARDIN (1979, p.21) afirma que: Na análise quantitativa, o que serve de informação é a freqüência com que surgem certas características do conteúdo. Na análise qualitativa é a presença ou ausência de uma dada característica de conteúdo ou de um conjunto de características num determinado fragmento de mensagem que é tomado em consideração.
\end{abstract}

A análise temática de um texto resume-se em extrair os núcleos de sentido que fazem parte da comunicação cuja presença tem alguma representação para o objeto definido (MINAYO, 1996). Tema é a unidade de significação que se liberta naturalmente de um texto analisado segundo critérios relativos à teoria que serve de guia à leitura (BARDIN, 1979).

Com base no exposto acima, demos início ao tratamento do material que, segundo Minayo (2001), permite conduzir à teorização dos dados, produzindo o confronto entre a abordagem teórica anterior e o que a investigação de campo aporta de singular contribuição.

E no sentido de operacionalizar o método foram seguidos os passos relacionados a seguir.

\footnotetext{
${ }^{12}$ GEORGE, A.L. Quantitative and qualitative approaches to content analysis. In: SOLA POOL. Trends in content analysis, Urbana: University of Illinois Press, 1959. p. 7-32.
} 
Foi realizada a ordenação dos dados que consistiu no mapeamento dos dados obtidos com a transcrição das gravações e novas leituras do material. Neste momento, as entrevistas foram separadas entre os diferentes estratos sociais.

Posteriormente foi feita a classificação dos dados por meio de leitura exaustiva e repetida do material. Por intermédio deste processo, foram identificadas estruturas relevantes que emergiram das falas, posteriormente as separamos em diferentes cartolinas por meio da colagem dos fragmentos das entrevistas.

Na pré-análise dos dados, foi realizada a leitura flutuante e a organização do material, para a constituição de um corpus $^{13}$ que corresponda às normas de validação como: exaustividade (que contempla todos os aspectos levantados no roteiro); representatividade (que contenha a representação do universo pretendido); homogeneidade (que obedeça a critérios precisos de escolha em termos de temas, técnicas e interlocutores); pertinência (os documentos analisados devem ser adequados ao objetivo do trabalho). Nesta fase préanalítica, determina-se a unidade de registro (palavra-chave ou frase).

E por fim, a análise final, na qual se estabeleceram articulações entre os dados e os referenciais teóricos da pesquisa, procurando responder às questões da pesquisa com base em seus objetivos. Este tratamento do material permite conduzir à teorização dos dados, produzindo o confronto entre a abordagem teórica anterior e o que a investigação de campo aporta de singular contribuição (MINAYO, 2001).

\footnotetext{
${ }^{13}$ Corpus: é o conjunto dos documentos tidos em conta para serem submetidos aos procedimentos analíticos. BARDIN, 1979)
} 
6 Resultados 


\section{RESULTADOS}

Os adolescentes se mostraram interessados em participar da pesquisa e aproveitaram o momento da entrevista para solucionar dúvidas sobre aspectos relacionados à halitose e à saúde bucal de modo geral.

Das escolas sorteadas, apenas a particular Vita et Pax, não tinha cirurgião-dentista presente na escola.

Refletindo sobre a atenção à saúde bucal oferecida pelo sistema público de saúde, notamos que existem lacunas, principalmente na parte curativa. O tratamento ortodôntico corretivo é inexistente no serviço público.

Atualmente com o surgimento de clínicas que oferecem convênios odontológicos para o tratamento ortodôntico, observou-se a democratização em termos financeiros do acesso a este tipo de tratamento, que antes era restrito às classes de maior poder aquisitivo. Neste estudo encontramos adolescentes que possuíam aparelho ortodôntico em todos os estratos sociais, realidade que não se notava anteriormente.

No intuito de exemplificar nossas considerações, citamos trechos das falas dos adolescentes. Tais trechos foram selecionados pelo critério de melhor representação da informação recebida, e não necessariamente por estrato social ou sexo. Uma vez que pelo critério da exaustividade, apresentavam homogeneidade.

Na exploração do material obtido, realizamos a análise temática, buscando os núcleos de sentido, que deram origem às seguintes temáticas:

“Halitose como um problema para o adolescente”

“Cuida da sua boca senão vai levar um fora” 


\section{1 "Halitose como um problema para o adolescente"}

Nesta temática, por meio da análise das falas dos adolescentes, depreendemos os significados atribuídos por eles à halitose e às pessoas que vivenciam tal problema, assim como foi possível analisar os reflexos da halitose nas suas relações sociais.

Evidenciada na fala dos sujeitos dos diferentes estratos sociais, a halitose traz aspectos negativos na vivência do adolescente.

Evidenciamos três núcleos de sentido, que foram: “boca de bueiro”, "sai de perto” e “ela não se toca que tem mau hálito?”.

\subsection{1 "Boca de Bueiro"}

Por intermédio das falas foi possível extrair os significado da halitose para os adolescentes. Para eles, a halitose sempre era definida como um cheiro ruim, algo sujo e nojento.

Segundo Rodrigues (1986), o ser humano é o único animal que se horroriza com suas secreções ou produtos corporais, e se sente cruelmente atingido por eles, porque é o único a possuir cultura.

A cultura de domesticação dos odores foi relatada em nosso histórico sobre a halitose, onde demonstramos que ao passar dos anos os odores corporais passaram a ser controlados buscando a discrição.

Muitas vezes os adolescentes faziam o uso de adjetivos ofensivos para definir e julgar o possuidor da halitose, abaixo citaremos algumas falas que demonstram tal fato.

D. Começaram a chamar ele de "bafão", carniça e túmulo (Feminino - 13 anos: estrato baixo). 
A. O dente fica amarelado, parece que é alguém que fuma e agente fica com um pressentimento ruim da pessoa (Masculino - 14 anos: estrato médio-alto).

B. Boca de bueiro, gambá e não escova os dentes direito (Masculino -13 anos: estrato médio-baixo).

M. São porcos, um pouco excluídos, recebem apelidos nada legais (Feminino - 13 anos: estrato alto).

Para as pessoas, os produtos do corpo não são nojentos, quando devidamente colocados em seu lugar e controlados pela própria organização biológica do corpo (RODRIGUES, 1986). Ou seja, possuir a halitose matutina fisiológica e realizar a higiene antes de encontrar outras pessoas não é um problema. Passa a ser, quando existe um descaso, descuido na higiene de quem possui a halitose.

Para eles, quem possui halitose é alguém que não se cuida, que é deficiente em sua higiene, salientam, também, que eles não devem gostar de si mesmos para permitir que tal fato aconteça. Entendemos “gostar de si mesmo”como auto-estima, e considerando nosso referencial teórico sobre adolescência, refletimos que a halitose pode afetar o processo de aquisição da auto-imagem, auto-estima e de identidade de quem possui o problema, uma vez que são todos interligados.

Pois, segundo Cavalcanti (1988, p.19), o aspecto nuclear da adolescência é a aquisição de identidade ${ }^{14}$. "Falam de auto-estima, auto-imagem, autoconceito, descoberta do eu, encontro de si mesmo. Mudam-se os nomes ao sabor dos teóricos, mas permanece, em todos

14 "Identidade é a consciência que o indivíduo tem de si mesmo como "um ser no mundo" (OSÓRIO, 1992, p. 14). 
eles, o enfoque do mesmo processo vital: "a conquista da identidade". O autor ainda afirma que o mais correto seria dizer a reelaboração do conceito de identidade, pois identidade não é algo estático que se consegue em determinado período da vida, e depois permanece imutável. Identidade é algo que se constrói por toda a vida, pois de certa forma o "eu individual" começa na infância com a noção da individualidade do corpo.

O processo de definição de identidade está intimamente ligado com a auto-imagem, que conseqüentemente está ligada à auto-estima. Segundo Briggs (2000), auto-estima é a maneira pela qual uma pessoa se sente em relação a si mesma, um sentimento de autorespeito, sentimento de próprio valor. A idéia que a pessoa faz de si mesma afeta sua criatividade, integridade, estabilidade, seus sentimentos do seu próprio valor formam a essência de sua personalidade.

Boff (2000) complementa, afirmando que o corpo vivo é subjetividade e junto com ele se realizam os vários níveis de consciência, expressando memórias e reforçando nossa identidade na interação com o outro. Essa interação ocorre na adolescência, principalmente por intermédio da turma.

Sendo o esquema corporal uma resultante intrapsíquica da realidade do sujeito, ou seja, a representação mental que o sujeito tem de seu próprio corpo como conseqüência de suas experiências em contínua evolução. O autoconceito vai se desenvolvendo à medida que o sujeito vai mudando e vai se integrando com as concepções que muitas pessoas, grupos e instituições têm a respeito dele mesmo, e vai assimilando todos os valores que constituem o ambiente social; concomitantemente, vai se formando este sentimento de identidade, como uma verdadeira experiência de autoconhecimento (ABERASTURY, 1981).

Nucci (2003) afirma que na co-existência e “con-vivência” do ser humano com o mundo, ele constrói seu próprio ser, sua autoconsciência e sua própria identidade, numa relação sujeito-sujeito, dentro de uma “inter-ação” e comunhão. 
As falas a seguir contemplam alguns exemplos de como os adolescentes vêem o possuidor de halitose:

C. Uma pessoa com bafo tem falta de cuidado, é fedorento, tem falta de atenção, é uma pessoa sem higiene, que não se repara (Masculino -13 anos: estrato baixo).

J. Eu acho que quando acontece essas coisas, é porque as pessoas não são cuidadosas com si mesma (Feminino - 14 anos: estrato médio-baixo).

E. Dente sujo, porquice, que não tem cuidado com a própria boca, que não se cuida, nem liga e também não procura tratar (Masculino 12 anos: estrato médio-alto).

T. Em questão de boca eu sou muito cuidadosa. Minha boca é a minha parte predileta, então quando eu vejo alguma coisa errada, eu fico meio incomodada (Feminino - 13 anos: estrato alto).

Outros adjetivos negativos vão sendo adicionados à imagem que os adolescentes fazem de quem não se cuida, surgem críticas quanto à beleza, e ao aspecto geral de sua higiene. Acreditam ainda que essas pessoas tenham problemas nos relacionamentos sociais e afetivos.

D. É horroroso, é sujo (Feminino - 13 anos: estrato baixo).

R. Pessoa com má escovação, pessoa com maus relacionamentos, pessoa porca (Masculino - 13 anos: estrato médio-baixo). 
A. A pessoa com mau hálito é uma pessoa de roupas sujas, que vai aos lugares deste jeito (Masculino - 14 anos: estrato médio-alto).

R. Todo mundo despreza. A minha classe até já inventou um nome que é "subacose" para mau cheiro embaixo do braço. (Uma derivação de halitose com sovaco) - (Masculino - 11 anos: estrato alto).

Tantos sentimentos negativos acabam refletindo no tratamento dado a estes. Por intermédio dessa representação negativa criada pelos adolescentes em relação a quem tem halitose, começam a surgir o preconceito e a discriminação. O que fatalmente o levará a ser estigmatizado pelos demais, afetando de forma negativa o desenvolvimento de sua identidade e auto-imagem.

Fatores estes que afetarão seu bem-estar emocional, que, segundo a conceituação de qualidade de vida de Felce e Perry (1996), envolve aspectos de amor próprio. O que podemos considerar como auto-estima.

Conseqüentemente interferindo na qualidade de vida dos adolescentes.

\subsection{2 "Sai de perto"}

Neste núcleo de sentido ficou bastante evidenciado o processo de estigmatização que sofre o adolescente que possui halitose. No sentido de melhor compreender este processo usaremos Goffman (1982) como nosso referencial sobre o estigma.

Estigma é uma situação do indivíduo que está inabilitado para a aceitação social plena, o termo estigma é usado em referência a um atributo profundamente depreciativo para uma pessoa marcada que deve ser evitada. A sociedade estabelece os meios de categorizar as pessoas e o total de atributos considerados como comuns e naturais para os membros de cada 
uma dessas categorias. Os ambientes sociais estabelecem as categorias de pessoas que têm probabilidade de serem neles encontrados.

O autor ainda complementa que um indivíduo que poderia ser facilmente recebido na relação social quotidiana possui um traço que pode impor a atenção e afastar aqueles que ele encontra, destruindo a possibilidade de atenção para outros atributos seus.

Esta afirmação se manifesta nas falas a seguir, nas quais podemos verificar que os adolescentes desprezam qualquer outra qualidade da pessoa para apenas ressaltar aquilo que o torna diferente dos demais. Existe uma superestimação de um problema com a conseqüente subestimação de outros valores.

C. Sabe... para mim escolher uma menina, eu vou escolher uma mais cuidadosa, que cuida das coisas. Agora uma menina com mau hálito, se ela não se cuida para isso, imagina das outras coisas! (Masculino - 13 anos: estrato baixo).

A. Eu não falei nada, só saí de perto. Me afastei (Feminino - 12 anos: estrato médio-baixo).

L.R. O meu amigo aqui da escola mesmo, foi ficar com uma menina, só que fora da escola. Aí quem tinha o mau hálito era ele, aí na hora que ele foi dar o beijo, ela começou a rir e chamou ele de bafudo. E aí ficou uma situação ruim, porque todo mundo ouviu e ficou rindo. Ele até saiu da escola, e ficou conhecido como bafão (Masculino - 11 anos: estrato médio-alto).

L. As pessoas já estavam começando a se afastar dele, as meninas nem queriam chegar perto dele (Feminino - 13 anos: estrato alto).

Weil e Tompakow (1999) comparam a caricatura com uma lente que pode focalizar a luz num só ponto de cada vez, ganhando em intensidade o que perde em extensão. Fazendo 
uma analogia desta afirmação com o estigma, percebemos que a focalização no problema acaba velando outras qualidades, produzindo uma exacerbação da diferença.

Somente a entrevistada abaixo teve sensibilidade ao perceber que apesar da pessoa ter halitose, ela permanecia com suas qualidades. E que merecia auxílio para conseguir sair desta situação de estigma.

L. Aí eu cheguei e dei um toque nele, que ele era uma pessoa linda, só que se ele continuasse assim ninguém iria querer ser mais seu amigo, ou até mesmo sua namorada (Feminino - 13 anos: estrato alto).

Quando o estigma é criado, essa discrepância estraga a identidade social. Ela tem como efeito afastar o indivíduo da sociedade e de si mesmo, de tal modo que ele acaba por ser uma pessoa desacreditada frente a um mundo não receptivo (GOFFMAN, 1982). Novamente citaremos que é na adolescência que ocorre a definição da identidade do adolescente e que ele possui necessidade de auto-estima elevada.

Em situações normais já existe um esforço em partilhar de semelhanças, qualidades e características com a turma, na presença de uma diferença que se torna um estigma, esse objetivo se torna um constante conflito para o adolescente.

A forma que os adolescentes agem perante este obstáculo é se afastar, ou seja, “sair de perto” excluindo quem o possui. O afastamento e a rejeição são tratados muitas vezes de forma direta, clara e sem cautela, o que fatalmente irá magoar o outro, trazendo embaraço e constrangimento.

Uma forma para um indivíduo reduzir a dissonância que sente ao maltratar uma pessoa que evidentemente não merece esse tratamento é convencer-se de que na verdade existe justificativa para seu comportamento. Uma forma de quem maltrata reduzir a dissonância é 
convencer-se de que a vítima merecia sofrer (BERSCHEID, 1973). Alguns exemplos de falas a seguir:

J.P. Porque quando a menina ficou com o moleque, ele começou a falar para todo mundo e o povo começou a fazer piada com ela. Chamavam ela de boca de bueiro...

Ela sempre chorava, né. Aí via que ela chorava e continuava (Masculino - 15 anos: estrato baixo).

G. Pode atrapalhar até as amizades. A coisa fica "meio embaçada" para conversar ele. Porque se ele tiver mau hálito todo dia o povo fica meio com medo, "meio embaçado" de conversar com ele, e ficar sentindo o cheiro. Ninguém é obrigado, né? Ninguém merece (Masculino - 14 anos: estrato-médio baixo).

I. Ele falava com você, você tinha que virar o rosto senão passava mal. É uma coisa horrível. Eu e minhas amigas apelidamos ele de “bafo de onça”. É muita zueira (Feminino - 15 anos: estrato baixo).

Os trechos anteriores demonstram que o estigma ocorre no ambiente escolar, local onde os adolescentes passam grande parte de seu dia. Essa situação confirma a afirmação de Goffman (1982) na qual ele diz que freqüentemente se assinala o ingresso na escola pública como ocasião para a aprendizagem do estigma, experiência que às vezes se produz de maneira bastante precipitada no primeiro dia de aula, com insultos, caçoadas, ostracismo e brigas.

O autor ainda complementa que, faltando o feedback saudável do intercâmbio social quotidiano com os outros, a pessoa que se auto-isola possivelmente torna-se desconfiada, deprimida, hostil, ansiosa e confusa. O indivíduo estigmatizado pode descobrir que se sente inseguro em relação à maneira como os normais o identificarão e o receberão. O estigmatizado e o normal são perspectivas que são geradas em situações sociais durante os 
contatos mistos, em virtude de normas não cumpridas que provavelmente atuem sobre o encontro.

Dentro de todo esse processo de preconceito, segregação e estigma, foram encontradas nas falas dos adolescentes observações acerca do aspecto profissional. No que diz respeito a empregos, eles acreditam que o mau hálito possa reduzir as chances no mercado de trabalho, principalmente nas funções que necessitem de contato interpessoal.

F. Tenho um amigo do meu primo que tentou arrumar emprego lá na TAM e não conseguiu por causa do mau hálito. Ele foi conversar com o chefe que eu mesma conheço, o meu primo trabalha lá. Aí o homem falou um monte de coisa, foi falando né... e o chefe falou: - Te ligo. E ele não conseguiu o emprego por causa do mau hálito. Porque o chefe da TAM é superamigo do meu primo, e ele contou que não vai dar, pois o mau hálito às vezes até atrapalha para atender clientes, essas coisas.

E o meu primo conversou com o moço e disse que não ia dar por causa disso (Feminino - 12 anos: estrato baixo).

I. Eu acho que muitas vezes, pode atrapalhar em uma entrevista de emprego (Masculino - 14 anos: estrato médio-alto).

A. Você é funcionário e vai conversar com o patrão da empresa, e nossa... sai o mau hálito. Você pode até ser despedido (Masculino 13 anos: estrato baixo).

J. Eu acho que o mau hálito pode atrapalhar na relação de trabalho. Por exemplo, se ele for um vendedor, na hora de falar com os clientes (Feminino - 11 anos: estrato baixo). 
Importante ressaltar que existiu diferença entre os estratos sociais, quando citavam os prejuízos que a halitose poderia causar nas relações de trabalho. Sendo esta preocupação mais presente, nos estratos menos privilegiados economicamente.

Cabe reflexão sobre este aspecto, no sentido de compreender se esta preocupação é maior porque a necessidade econômica se mostra freqüente se tornando uma perturbação, ou ainda, devido ao fato de que notadamente os adolescentes de estrato social mais privilegiado normalmente iniciam no mercado de trabalho mais tardiamente.

Outro fator a ser considerado é a forma como os adolescentes reagem perante o possuidor de halitose, existe um constrangimento em avisar a pessoa de seu problema. Acreditam que existiria uma situação embaraçosa e constrangedora que poderia até ser encarada como falta de respeito.

Muitas vezes os amigos preferem se afastar a comunicar à pessoa de seu problema. As falas a seguir representam alguns exemplos desta situação.

J. Você tenta disfarçar que a pessoa não está, mas...não tem jeito. Você tenta deixar de lado, cortar o assunto (Masculino - 14 anos: estrato médio-baixo).

T. (Risos) Eu estava conversando e senti. Eu abaixei a cabeça (risos). Sei lá.... quando ela for conversar com alguém. Aí o povo sai andando (Feminino - 14 anos: estrato alto).

É importante salientar, como já discutido neste estudo, na parte sobre a fisiologia da sensibilidade olfatória, que o epitélio olfativo se fadiga rapidamente, sendo suscetível à grande adaptação. O que faz com que o adolescente que possua a halitose desconheça seu problema.

Diante do dilema: não vou avisar versus não sabe que tem, permanece a problemática. 
Com o intuito de desmistificar esta situação, criou-se um site na internet, idealizado pela Associação Brasileira de Estudos e Pesquisas dos Odores da Boca (ABPO) por meio do qual é possível avisar o indivíduo de que ele possui mau hálito de forma anônima, discreta e com informações para que ele possa vir a se cuidar. O endereço do site é este: http://www.abpo.com.br.

Durante as entrevistas, em várias ocasiões os adolescentes demonstravam acanhamento e risos ao falar sobre o assunto halitose. Isso reforça as afirmações consideradas no histórico deste trabalho, nas quais, os autores demonstram que através dos tempos a etiqueta corporal passou a ser a discrição.

Entretanto, com o aumento das informações a respeito da halitose, se tornará mais simples esta comunicação. Pois, odores corporais ainda ocupam o patamar da reserva, chacota ou ainda da zombaria.

Percebendo que se trata de uma situação que é passível de acontecer a qualquer um de nós, talvez fique mais fácil a comunicabilidade.

Em raras entrevistas, obtivemos alguns depoimentos de adolescentes interessados em ajudar o próximo de forma mais sutil, com o intuito de orientar e contribuir, seja avisando-o ou ainda orientando.

C. Eu tava conversando com ele, aí começa a sair aquele "fedô". E ele sabe né? Aí eu falo para ele comprar aquela coisa que minha mãe comprou de chacoalhar assim. (ele estava falando de soluções antisépticas para bochecho).

E ele falou bem assim: - Ah então tá bom. E eu mostrei para ele como que é, para ele poder comprar.

Porque se ele for chegar em alguma pessoa assim importante, e for conversar com a pessoa, ele vai sentir vergonha. Porque a pessoa vai falar (Masculino - 13 anos: estrato baixo). 
L. Eu estava conversando, aí eu perguntei por que ela estava. E ela disse que não tinha comido nada. Aí ela foi se cuidar (Feminino - 13 anos: estrato alto).

Com a possibilidade de solução do problema da halitose, o adolescente pode voltar ao seu convívio social de forma plena e confiante, podendo, dessa forma, vivenciar esta fase já tão rica em turbulências de forma mais tranqüila. Como exemplo, temos a fala a seguir que demonstra a mudança de comportamento de uma adolescente ao poder reaver sua segurança e desinibição para ter uma vivência tranqüila de sua sexualidade.

M. Minha melhor amiga, ela tinha mau hálito, agora ela fez um tratamento e não tem mais. Ela me disse que era muito ruim ter mau hálito, agora ela pode conversar com os meninos.

Antes ela tinha vergonha do seu mau hálito. Agora ela abraça e dá até beijos no rosto dos meninos (Feminino - 11 anos: estrato médiobaixo).

Reportando ao nosso referencial de qualidade de vida, pudemos observar que este núcleo de sentido evidencia também prejuízo no bem-estar emocional, que contempla além dos fatores já citados, o respeito e o pensamento positivo, que em um processo de estigmatização fatalmente serão atingidos.

Também podemos considerar que existe prejuízo no aspecto do desenvolvimento e atividades, pois segundo os adolescentes, o trabalho também pode ser afetado na presença de halitose. 


\subsection{3 “Ela não se toca que tem mau hálito?”}

Nos núcleos de sentido anteriormente citados, refletimos sobre alguns aspectos tais como: a formação da identidade, a auto-imagem, auto-estima e o estigma.

Tais fatos se interligam com este núcleo que iniciamos agora. Pois este reflete a interferência da halitose nas experiências de vivência em grupo, nas relações sociais e conseqüentemente na qualidade de vida. De acordo com o que concebemos em nosso referencial teórico, qualidade de vida é um conceito que contempla múltiplos aspectos.

Este núcleo reflete a interferência no aspecto do bem-estar social na qualidade de vida dos adolescentes.

Werebe (1998) sustenta que, na adolescência, as amizades constituem a forma de relação privilegiada mais importante. A uniformidade proporciona segurança e estima pessoal. Aí surge o espírito de grupo pelo qual o adolescente se mostra tão inclinado. Há um processo de superidentificação em massa, onde todos se identificam com cada um (ABERASTURY, 1981).

A turma nesse momento de vida representa um grande passo no sentido da socialização comunitária do adolescente. Segundo Tiba (1986), na turma o adolescente se sente entre as pessoas que estão no mesmo momento existencial, ficando uniformemente originais.

Por intermédio das entrevistas, pudemos perceber que a halitose compromete a sociabilidade, prejudicando a comunicação e a aproximação interpessoal, reduzindo o círculo social de amizades e prejudicando a inclusão na turma.

Em relação à convivência social entre amigos, os fatos evidenciados nas falas abaixo exemplificam nosso entendimento. 
A. Eu acho que ela pode perder as amizades. Porque ela tem um monte de amigos, e os amigos chegam perto dela e começam a sentir uma coisa estranha por causa do hálito dela. Então eles querem ter distância dela. E com isso ela vai perdendo os amigos. E isso atrapalha as relações (Masculino - 13 anos: estrato baixo).

J. A pessoa vai ter menos amigos, pois eles vão ter nojo dela (Masculino - 13 anos: estrato alto).

Berscheid (1973) afirma que uma pessoa que aceita a si mesma terá melhores relações interpessoais com outras. E que quanto mais baixo o nível de amor próprio de uma pessoa, maior sua necessidade dos apoios dados pela aceitação num grupo.

Segundo Tiba (1986, p.15), "uma das situações que os púberes menos suportam é a de se sentirem diferentes ou anormais perante os outros". Somando-se a isso existe o fato de que adolescentes possuem uma deslocalização temporal, na qual convertem o tempo presente e ativo, numa tentativa de manejá-lo. Para eles as urgências são enormes e, às vezes, as postergações são aparentemente irracionais (ABERASTURY, 1981). Ou seja, além de não suportarem ser diferentes, ainda possuem pressa para solucionar tal problema.

Refletimos, portanto, que o mau hálito consegue antepor uma barreira invisível entre as pessoas, prejudicando a vivência grupal tão almejada pelo adolescente.

Para Heidegger (2001), cuidado significa zelo, desvelo, atenção e bom trato. Para os adolescentes, quem tem mau hálito é alguém que não se cuida. As pessoas gostam dos que têm atitudes semelhantes às suas (BERSCHEID, 1973), dessa forma, quem não se cuida é diferente, portanto não pertencem ao mesmo grupo.

Nucci (2003) sustenta que cuidar de si significa cuidar da vida, das relações, do espaço que ocupamos, envolvendo auto-conhecimento, amadurecimento, autonomia e liberdade. Cuidar é entrar em sintonia, afinar-se consigo mesmo, com o outro, com o mundo. 
Essa sintonia com o outro e com o mundo também é conseguida por meio da turma. Nas falas dos adolescentes transcritas a seguir, fica bem clara a necessidade de que o grupo aprove as suas escolhas.

E. Eu não ia ficar com ela, porque se ela tivesse mau hálito eu iria mostrar para os meus amigos e eles iam falar que a minha namorada tem mau hálito (Masculino - 12 anos: estrato médio-alto).

J. Eu perguntei para o meu amigo: - Como você consegue ficar com ela? Ela não se toca que tem mau hálito? (Masculino - 14 anos: estrato-médio-baixo).

Sendo um relacionamento, um padrão de interação entre duas pessoas, baseado em suas percepções recíprocas (LITTLEJOHN, 1982), evidencia-se de forma clara que a halitose pode comprometer esse propósito. Dessa forma, para os adolescentes que sofrem com o mau hálito, a necessidade de se sentir parte de um grupo vai se tornando um sonho cada vez mais distante.

I. Na hora de conversar com os amigos. Você sente aquele cheiro desagradável e atrapalha o relacionamento (Masculino - 14 anos: estrato médio-alto).

T. O mau hálito atrapalha nos relacionamentos, porque todo mundo fica incomodado com isso. Porque essa menina que tem mau hálito, quando ela chegava na escola ninguém suportava. Ela ainda tem, desde o ano passado (Feminino - 13 anos: estrato alto). 
Nessa fase da vida em que se está mais atento ao próprio corpo, a suas semelhanças e também às diferenças em relação ao corpo dos outros (PALÁCIOS, 1995), a presença de mau hálito pode se tornar um fator que diferencia e segrega o adolescente.

Ponderando sobre os aspectos da comunicação humana, sabemos que a comunicação interpessoal ocorre no contexto da interação face a face, e que ela é um processo de estabelecimento e manutenção de relações, onde ocorre permuta recíproca de pistas verbais e não-verbais (LITTLEJOHN, 1982).

A linguagem corporal ou comunicação não-verbal tem um papel central no comportamento social humano. Os sinais não-verbais são: a expressão facial, o olhar, gestos e movimentos corporais, posturas, contato corporal, comportamento espacial, roupas e outros aspectos da aparência, vocalizações não-verbais e cheiro (ARGYLE, 1990).

O autor ainda complementa que os principais sinais corporais que demonstram “gostar” são: em relação à proximidade - ficar mais perto; em relação à orientação - ser mais direto; em relação ao olhar - olhar mútuo, olhar mais; e finalmente em relação à expressão facial, que se torna mais sorridente.

E que a comunicação corporal possui diferentes funções, tais como: expressar emoções, comunicação de atitudes interpessoais, acompanhar e dar suporte à fala, apresentação pessoal e rituais.

Segundo Stefanelli (1993), a comunicação é um processo de compreender, compartilhar mensagens enviadas e recebidas, sendo que as próprias mensagens e o modo como se dá seu intercâmbio exercem influência no comportamento das pessoas nele envolvidas. E que a comunicação não-verbal se torna um aspecto importante na comunicação, pois não temos controle consciente sobre ela.

Numa conversa humana, nosso mundo interior de conceitos e de idéias, nossas emoções e nossos movimentos corporais tornam-se estreitamente ligados numa complexa 
coreografia de coordenação comportamental (CAPRA, 1996, p.227). Dentro desta coreografia, existe uma distância considerada “correta” que deve ser mantida, é uma norma inconsciente, o ajustamento à distância correta é feita automaticamente pelos participantes.

De modo geral, parece que ficamos mais próximos das pessoas de que gostamos do que daqueles de que não gostamos. Quanto menor a distância física entre dois indivíduos, maior a probabilidade de que sejam mutuamente atraídos (BERSCHEID, 1973).

Já Weil e Tompakow (1999) afirmam que quando se inclina o corpo para trás durante um diálogo, isso demonstra recuo, rejeição e afastamento.

Diante dessas afirmações, podemos refletir sobre algumas situações explicitadas pelos adolescentes em suas falas. A forma que a maioria lida com a situação de incômodo com o mau hálito alheio é se afastar, e se afastando, o adolescente emite sinais não-verbais de insatisfação e desaprovação em relação ao adolescente com halitose.

Sinais não-verbais podem ser enviados muitas vezes de forma inconsciente. Mesmo sem querer, o adolescente pode estar demonstrando ao colega que o desaprova.

A face é o principal canal para a comunicação não-verbal, ela é particularmente importante por expressar emoções, atitude para outra pessoa. A expressão facial muda rapidamente e tem um papel importante na interação social (ARGYLE, 1990).

Berscheid (1973) verificou que a freqüência de olhares tem correlação positiva com o fato de um indivíduo gostar de outro, bem como o desejo que tem de iniciar ou manter interação com o outro.

Complementando, temos a afirmação de Davis (1979) sobre o fato de que o olhar firme está diretamente relacionado com o agrado, ou seja, desviar o rosto demonstraria desinteresse e desagrado. 
E. Eu afasto um pouco porque eu não gosto de ficar sentindo mau hálito. E eu fico tentando não olhar no rosto, fico disfarçando (Masculino - 12 anos: estrato médio-alto).

L. Eu estava conversando e senti um hálito bem forte. Foi me incomodando e eu fui me afastando dele. Virava a cabeça... (Feminino - 12anos: estrato médio-alto).

Outro ponto que merece destaque é a satisfação das necessidades do ser humano. Maslow (1970) afirma que tendo asseguradas, pelo menos razoavelmente, as necessidades de segurança, as pessoas sentem a necessidade de laços afetivos com os demais, a necessidade de obter um lugar em seu próprio grupo e no mundo. Aparecem assim, as necessidades de amor, não como sinônimo de sexo, mas como o sentido de ser compreendido e aceito plenamente por alguém.

Refletindo sobre a teoria de Maslow (1970), podemos considerar que a presença de halitose pode começar a interferir desde o terceiro nível que é o das necessidades sociais, dificultando o acesso ao próximo objetivo, que vem a ser a necessidade de auto-estima. Impedindo, dessa forma, que o adolescente chegue à auto-realização e atinja a almejada qualidade de vida.

\section{2 “Cuida da sua boca senão vai levar um fora”}

Esta temática evidenciou o conhecimento que os adolescentes têm sobre a halitose e as estratégias que eles utilizam para a sua prevenção, assim como também os reflexos da halitose nos relacionamentos de namoro. Foram evidenciados os seguintes núcleos de sentido: namoro, conhecimento e como enfrenta a situação (prevenção). 


\subsection{1 “Namoro”}

É conflitivo para o adolescente tentar namorar, caso ele tenha dúvidas sobre sua própria identidade; quando ele estiver mais integrado psíquica e fisicamente consigo mesmo, ele terá maior segurança, para buscar relacionamento com pessoas do outro sexo. (TIBA, 1986). O autor ainda reforça que além da busca da identidade e da independência, o adolescente busca a sua importância afetiva, ou seja, ele é afetivamente importante para alguém?

O namoro é uma importante etapa no desenvolvimento do ser humano, trata-se de um relacionamento social-afetivo-sexual. No namoro vem à tona a auto-imagem, as imagens internalizadas e as externas do homem e da mulher, o modelo de relacionamento dos pais, a revisão da matriz de identidade, a visão com perspectiva de futuro (TIBA, 1986).

O autor ainda complementa que ter boa auto-estima é gostar e valorizar a si mesmo. Quem não gosta de si mesmo dificilmente aceita que seja gostável por outra pessoa.

Sendo possuidor de tantos significados, o namoro ou ainda o atual "ficar" são manifestações saudáveis ao desenvolvimento normal do adolescente, sendo o beijo uma íntima aproximação, na qual o hálito é compartilhado.

Como já afirmamos, os odores nos afetam em níveis físico, psicológico e social. É natural que com o aumento da proximidade e o crescimento da intimidade, o adolescente passe a compartilhar o hálito do outro. Seja pelo beijo ou ainda por um contato sexual.

Situações típicas da adolescência como a insegurança, a sensação de inexperiência e de descontrole sobre o corpo podem ser exacerbadas, se este apresentar halitose. Pois muitas vezes o adolescente pode estar sofrendo rejeições do sexo oposto, por uma razão prosaica como a halitose, e não pelas possíveis razões complexas por ele elucrubadas. 
Assim como, também, compromete a sexualidade, por intermédio do empecilho imposto aos relacionamentos afetivos esporádicos ou duradouros. O “ficar” é aqui definido como: manter com alguém convívio de algumas horas, sem compromisso de estabilidade ou fidelidade amorosa.

É importante salientar que, durante as entrevistas, quando os adolescentes iriam começar a falar de namorar ou de “ficar”, se preocupavam em verificar se não teria alguém da escola ouvindo a conversa, demonstrando cautela em falar de assuntos íntimos.

Outro fator, notado pela entrevistadora, foi que os adolescentes sempre procuravam projetar a situação contada para uma terceira pessoa, que poderia ser um amigo ou conhecido. Tentando com essa estratégia desvincular o assunto halitose de sua pessoa.

Destacamos, aqui, que a imagem que o adolescente elabora sobre o próprio corpo é em parte derivada do produto de suas vivências na interação social e, em parte, o resultado de sua própria avaliação de suas expectativas e fantasias (CAVALCANTI, 1988). Dessa forma, se o adolescente tiver suas interações sociais prejudicadas pela halitose, possivelmente poderá criar fantasias negativas e ter suas expectativas reduzidas.

Quando um adolescente é recusado, ele pode abstrair várias hipóteses, ligar outros acontecimentos passados, agrupar informações sobre o outro advindas de outras pessoas. E na sua auto-referência freqüentemente o outro o rejeitou também por algum problema seu (TIBA, 1986).

Para Outeiral (1994), na adolescência, o corpo físico assume dimensão significativa na vida do adolescente, e uma vez iniciada as transformações corporais, o jovem passa a assistir e a viver todo esse processo passivamente, sem poder interferir, o que determina intensa ansiedade e cria inúmeras fantasias, ocasionando situações ou momentos de afastamento ou isolamento social. 
Ainda considerando nosso referencial teórico, podemos afirmar que se este começar a criar fantasias negativas sobre sua auto-imagem, certamente será prejudicado em sua autoestima. Levando a um prejuízo na vivência de sua sexualidade o que conseqüentemente afetará sua qualidade de vida, pois segundo Felce e Perry (1996), a sexualidade faz parte do bem-estar emocional que é necessário à qualidade de vida.

Todos necessitam ter auto-estima elevada, no entanto, o adolescente necessita fundamentalmente saber que os outros pensam bem dele, e que se sentem bem como pessoa, com seu corpo, seus afetos e suas idéias (DONAS, 1992). Essa segurança é necessária para que ele se sinta apto a exercer sua sexualidade por meio de relacionamento afetivo com outras pessoas.

O adolescente possui uma enorme necessidade de reconhecimento por parte dos outros, precisa ver sua identidade reconhecida e aceita pelas pessoas que sejam significativas para ele. É por meio deste reconhecimento e aceitação que ele assegura um conceito positivo de si mesmo (FIERRO, 1995).

Diante disso reconhecemos nas falas a seguir situações em que a auto-estima do adolescente pode ser prejudicada. Pois a rejeição ocorrida pela halitose pode levá-lo a nutrir ainda mais sua insegurança. Talvez até alimentando fantasias negativas sobre sua autoimagem, o que irá interferir em sua sexualidade.

Pois a sexualidade, é sobretudo, um elemento estruturador da identidade do adolescente. E essa função estruturante é, em grande parte, realizada na representação mental que o adolescente tem de seu corpo, ou seja, pela sua imagem corporal (OSÓRIO, 1992).

A. Eu falei para ele: - eu não quero mais não, deixa prá lá. Na hora que eu senti eu desisti. Depois ele chegou no dia seguinte e me perguntou: - Por que você não quis ficar comigo?

E eu falei o porquê. Aí ele falou: - Foi mau... foi mau... 
Tinha muita gente perto na hora que eu neguei, e ele veio depois no canto me perguntar. E ele ficou muito sem graça.

Ele tem que se cuidar para não levar fora das meninas, se cuidar mais. Eu vou dar um recado: - Cuida da sua boca senão vai levar um fora!! Qualquer pessoa não faz isso pela segunda vez, né? Me dá nojo de ver, credo!!! Tem um "fedô", é horrível! (Feminino 12anos: estrato médio-baixo).

T. A minha amiga tem mau hálito e ela falou que o menino saiu no meio do negócio. Ele ia começar a beijá-la e sentiu o cheiro, aí saiu no meio do negócio (Feminino - 14 anos: estrato alto).

I. Ele foi beijar e ela sentiu o mau hálito e disse que não queria ficar com ele. E saiu fora (Masculino - 14 anos: estrato médio-alto).

T. Essa mesma pessoa que te falei que tem mau hálito, todo mundo se pergunta como ela consegue ficar com alguém. Ela diz que fica, mas deve ser mentira.

Por que como alguém vai ficar? Mas como, né? Só se o menino também tiver, né? (Feminino - 13 anos: estrato alto).

Davis (1979) nos lembra que, na atração, devem ser considerados a expressão facial, a proximidade e o contato físico. Todas essas manifestações citadas são prejudicadas durante o contato com o possuidor do mau hálito.

Em uma conversa íntima onde existe proximidade física, as pessoas se comunicam não só através de palavras, como também do tato, do cheiro e do calor do corpo, dessa forma, os odores bucais podem representar atração e encantamento ou repulsa e rejeição.

O bem-estar relacionado à vida social e emocional se torna bastante relevante e necessário à qualidade de vida, pois o adolescente precisa passar por este período de descoberta de sua sexualidade de forma tranqüila, pois a própria fase em si já possui suas turbulências. 
Os adolescentes rejeitados por sua halitose podem ficar à margem desse processo. A raiz das ansiedades do adolescente com respeito a seus atributos físicos é a desejada capacidade de atrair o sexo oposto (OSÓRIO, 1992).

Importante salientar que, em nosso referencial, comentamos que um importante foco da preocupação com os odores do corpo era o hálito, pois assim como um beijo perfumado era um ideal romântico, o mau hálito fazia com que o indivíduo fosse alvo de repugnância e zombaria. Verificamos essa permanência cultural nas falas dos adolescentes participantes da pesquisa.

D. Depois disso nenhuma menina queria ficar com ele, foi a maior "paiaçada” (risos). Começaram a chamar ele de "bafão" (Feminino - 13 anos: estrato baixo).

\subsection{2 "Conhecimento"}

Este núcleo de sentido reflete o conhecimento que os adolescentes possuem em relação à halitose.

Devido à multiplicidade dos fatores etiológicos que podem ocasionar a halitose, é natural que haja dúvidas quanto à sua etiologia. Pois muitas vezes a presença de halitose se deve a mais de uma causa.

A falta de higiene ou higiene deficiente foram as principais razões mencionadas pelos adolescentes em relação à etiologia da halitose.

M.T. É quando a gente não escova os dentes e fica comida nos dentes e dá mau cheiro (Feminino - 12 anos: estrato baixo). 
A. Não escovar os dentes, não passar fio dental, os dentes ficarem amarelos. O meu pai sempre fala que se ficar com os dentes amarelos vai ficar "fedô" (Masculino - 12 anos: estrato médio-baixo).

E. Eu acho que é o que dá na boca quando não escova os dentes (Masculino - 12 anos: estrato médio-alto).

T. Eu acho que é sujeira nos dentes. Porque quem não escova os dentes vai acumulando, e vai ficando um cheiro meio ruim, meio desagradável (Feminino - 13 anos: estrato alto).

Ainda em relação à etiologia, alguns adolescentes afirmaram não saber as razões da ocorrência da halitose, pois alegam que o problema persiste, mesmo após a escovação.

J.P. Não sei... porque quando eu escovo os dente, eu escovo, e fico com mau hálito também. Minha mãe avisa eu, e eu escovo meus dentes. Mas, eu vejo que não adianta só escova os dente para não ficar com mau hálito (Masculino - 15 anos: estrato baixo).

J. O que causa o mau hálito, eu não sei (Masculino - 14 anos: estrato médio-baixo).

Outros afirmam que a halitose é originada na garganta, apesar de as principais razões para a ocorrência da halitose estarem presentes na boca, as afirmações estão corretas, pois a halitose pode ser derivada de infecções de garganta, ou ainda pela presença de cáseos.

Os cáseos são acúmulos de placa bacteriana nas criptas das amídalas, originando o mau odor. Um dos adolescentes abaixo relata possuir mau hálito devido à presença destes.

E. A dor de garganta dá mau hálito (Feminino - 12 anos: estrato médio-baixo). 
L. É tipo quando fica sujeira na língua, não é? E problemas de garganta, eu tenho um problema nas amídalas, elas são perfuradas e acumula sujeira. Agora estou fazendo um tratamento com o médico de homeopatia. Porque o outro disse que queria retirar minhas amídalas (Masculino - 12 anos: estrato médio-alto).

G. Acho que é... alguma coisa que tem na garganta que faz dar mau hálito (Masculino - 12 anos: estrato alto).

Também citaram a halitose por baixa glicemia, que ocorre devido a jejum prolongado, grande intervalo entre as refeições ou a chamada de halitose da fome e do regime. Essa situação ocorre porque com a baixa do açúcar no sangue, começa a efetuar-se a queima de gordura que, ao final do processo, gera corpos cetônicos que são eliminados pela via respiratória por intermédio da boca.

A. Não sei, tipo minha mãe, quando está com fome dá mau hálito, eu também. Depois a gente come, escova o dente e passa. Agora, não sei se é pelo fato de escovar os dentes ou por isso (Feminino - 13 anos: estrato médio-baixo).

L. A pessoa não come porque não quer engordar, então isso causa o mau hálito (Feminino - 13 anos: estrato alto).

A desidratação gera a diminuição da produção de saliva, facilitando o depósito de saburra no dorso lingual, originando a halitose. A fala da adolescente reproduz a informação obtida de forma correta.

M. Sei, mais ou menos, é ficar sem escovar os dentes, e quem toma pouco líquido. Minha mãe e a dentista me orientam (Feminino - 13 anos: estrato médio-alto). 
Em algumas entrevistas, observamos que alguns adolescentes possuem conceitos errôneos sobre a halitose, algumas falas são reproduzidas abaixo.

L.R. O mau hálito acontece quando se tem bactérias mortas na boca (Masculino - 11 anos: estrato médio-alto).

J. Me falaram que se escovar a língua com a escova, é perigoso você perder o que você sente na língua (Masculino - 14 anos estrato médio-baixo).

Juntamente com a desinformação, temos o agravante de que os adolescentes estão sujeitos a inúmeras fragilidades, segundo Brew; Pretto e Ritzel (2000) eles possuem maior facilidade às inflamações e infecções, problemas com a higiene e cuidados pessoais e dieta quase sempre inadequada.

Os autores ainda complementam que é nesse período em que ocorre a grande maioria das trocas dentárias. Essa mudança não implica somente a troca de um dente por outro, mas traz consigo várias alterações na cavidade bucal, tais como modificações na saliva, maior facilidade para a retenção de alimentos e maior dificuldade na higienização, propiciando o desenvolvimento de doenças bucais.

Tais modificações fisiológicas no ambiente bucal fazem parte do período e fogem ao controle do adolescente.

É importante também salientar que é na adolescência que ocorre o irrompimento do terceiro molar, chamado popularmente de dente do siso. E muitas vezes ocorre a pericoronarite (inflamação do tecido que está recobrindo a coroa do dente), patologia que gera dor, desconforto e mau hálito.

As mudanças bucais associadas às outras modificações corporais decorrentes da puberdade levam ao adolescente a sensação de descontrole sobre o corpo. 
Embora a pesquisa tenha sido feita em diferentes estratos sociais, observamos que não existe divergência significante entre as falas dos entrevistados. O conhecimento que os adolescentes possuem em relação à halitose se mostrou equivalente nos diferentes estratos estudados.

No entanto, é importante citar que na escola de estrato baixo - EMEF. Prof. José Rodini Luiz, os alunos relataram que haviam recebido uma palestra da dentista da escola sobre o assunto um mês antes da entrevista.

Os significados atribuídos pelos adolescentes à halitose podem ser considerados senso comum. Segundo Gramsci (1978), senso comum é a síntese espontânea do que pensam as pessoas no ambiente social.

O aumento de informações em relação à saúde bucal é essencial, atualmente se observa por meio de dados epidemiológicos que existe uma diminuição de algumas doenças bucais, e isso de deu devido a vários fatores e, dentre eles, ao aumento das orientações acerca de prevenção e promoção da saúde.

Com o declínio da incidência de cáries (MARCENES; BÖNECKER, 2000), outros problemas emergem em relevância. Podemos considerar que a halitose é um deles, pois sua presença pode limitar a qualidade de vida do adolescente. Considerando que esta "fórmula" tem dado certo, não vemos o porquê de não incluirmos uma maior atenção a este problema por meio da educação em saúde.

Pensar em educação em saúde é pensar em multiplicadores, ou seja, permitir que a informação seja difundida para o maior número de pessoas. Seja por meio dos professores, ou pais e ainda os próprios alunos.

Ao refletirmos acerca deste núcleo de sentido, foi possível relacionar o aspecto desenvolvimento e atividades da conceituação de qualidade de vida que aborda a necessidade de independência, controle e educação. 
Criar estratégias e ações educativas que possibilitem que o adolescente tenha o autocuidado, é permitir independência e controle sobre sua saúde.

\subsection{3 “Como enfrenta a situação” (prevenção)}

No sentido de tentar mascarar o possível mau odor bucal, os adolescentes relatam fazer uso de balas, chicletes e pastilhas ardidas. Relatam, ainda, ser muito comum sempre as levarem consigo de modo preventivo quando vão sair, mostrando-se prontos para qualquer situação.

A necessidade de controlar o odor bucal se faz presente no intuito de se mostrar mais atrativo e sedutor, exercitando assim sua sexualidade.

Em nosso histórico, demonstramos que sempre existiu a atenção dirigida a mascarar os odores bucais, visando à aprovação alheia. Situação presente ainda hoje, conforme podemos observar nos relatos abaixo:

G. Era ela que estava com mau hálito, e eu chupei uma bala para disfarçar e dei uma para ela. Sempre que sai tem que ter chiclete. Todo mundo que conheço leva alguma bala ou chiclete quando vai sair (Masculino - 14 anos: estrato médio-baixo).

L. Mas, eu acho que é bom sempre levar uma balinha. As pessoas comentam... (Feminino - 13 anos: médio-baixo).

No entanto, mascarar não é tratar a halitose, é apenas uma tentativa de atenuar o problema. Por meio das falas foi possível observar que como os adolescentes não sabem corretamente a etiologia da halitose, naturalmente não sabem como preveni-la e tratá-la.

A limpeza da língua como procedimento de prevenção também foi citada, porém em menor número. 
R. Eu... (risos) Eu tinha mau hálito. Eu percebi porque na $4^{a}$ ou $5^{a}$ série eu comecei a ter. Porque eu escovava os dentes, mas não escovava a língua.

Eu acho que são os restos microscópicos de alimento que ficam na língua, e se não for escovar eles vão ficando cada vez maiores e causam o mau cheiro. Se não escovar direito causa este tipo de problema (Masculino - 11 anos: estrato alto).

J. Não escovar os dentes e não escovar a língua, porque fica aqueles negócio branco na língua. Eu acho que isso que causa o mau hálito (Feminino - 14 anos: estrato baixo).

L. É tipo quando fica sujeira na língua, não é? (Feminino - 12 anos: estrato médio-alto).

Surpreendeu-nos o fato de que diversos adolescentes aprenderam por intermédio de programas de televisão como prevenir a halitose. Nestes programas uma dentista dava as explicações. Constatamos que a dentista presente em diversos programas foi a Dra. Ana Christina Kolbe, fundadora da Associação Brasileira de Estudos e Pesquisa dos Odores da Boca (ABPO) e criadora do limpador de língua Kolbe .

M.T. Já, porque eu vi uma reportagem no Gugu, que falava que fica um negócio na língua que causa o mau hálito. E existe um negócio de limpar (Feminino - 12 anos: estrato baixo).

E. No Ratinho, levaram duas mulheres lá e fizeram o teste do bafômetro, e tem aquela escova que você limpa e depois raspa, e se não tiver passa uma colher para limpar (Masculino - 12 anos: estrato médio-alto).

R. Eu soube pelo programa do Ratinho, na $5^{a}$ série ele passava à tarde. Eu comecei a assistir,e eles estavam falando de mau hálito e 
tinha um raspador que passava na língua para tirar o mau hálito (Masculino - 12 anos: estrato alto).

A proposta tem seu mérito, no entanto, o ideal seria que esse fosse eventualmente um recurso complementar às orientações dadas pelos profissionais da odontologia aos seus pacientes. Mas o que se percebe, é que poucos se preocupam em “perder tempo” com as orientações, tal situação talvez ocorra devido ao grande número de dentistas que conseqüentemente tem cada vez menos pacientes. E na tentativa de melhorar o retorno financeiro, realiza consultas cada vez mais breves buscando maior rendimento.

Acreditamos que os dentistas, presentes nas escolas, deviam seguir o exemplo da dentista citada (escola - EMEF. Prof. José Rodini Luiz), sendo dessa forma, mais bem aproveitados no sentido de elaborar propostas educativas com a população de sua escola, incluindo atividade para professores e também para pais de alunos. Por intermédio de levantamento epidemiológico, o dentista pode avaliar a situação da saúde bucal dos alunos da escola e planejar ações direcionadas às maiores necessidades.

Interessante ressaltar que limpadores linguais já existem há muito tempo, como citamos em nosso referencial, os japoneses no século VI já realizavam a raspagem da língua, antes das primeiras orações matinais. Como tal informação se tornou perdida por tantos anos? Apesar de resgatado, esse conhecimento ainda é subutilizado.

Também encontramos que o fio dental é pouco utilizado, por razões diversas, tais como: preguiça, dificuldade, pressa ou ainda devido ao seu preço. Convém reiterar que de fato o valor cobrado pelo fio dental é muito alto, tornando-o um bem inacessível aos estratos menos privilegiados economicamente.

O relato a seguir de uma adolescente do estrato baixo é surpreendente. Pois mesmo em situação financeira de grande dificuldade, esta jovem adquiriu informações corretas e necessárias conseguindo com criatividade solucionar suas privações. 
M.T. Porque assim... eu moro na favela, mas mesmo assim os meus pais compram escova de dente para mim, mas as outras coisas não dá o dinheiro. Quando eu não tenho pasta, eu escovo com a água. E uso linha de roupa como fio dental.

Eu sei que existe um negócio de limpar a língua, mas eu não tenho, então eu pego um negócio "retinho" que eu tenho e passo na língua para limpar. E a sujeira cai no papel e eu limpo

Eu tenho uma amiga que se ela comprar a pasta e a escova ela não terá dinheiro para comprar leite para a filha dela (Feminino - 12 anos: estrato baixo).

Apesar de essa adolescente ter conseguido sanar seu problema, é uma situação inaceitável que o fio dental tenha um custo tão elevado, pois ele é essencial aos métodos de prevenção das doenças bucais, não somente em relação à halitose, como também a doença cárie e a doença periodontal.

Segundo Axelsson (1994), 92\% do incremento da cárie em adolescentes brasileiros, entre 12 e 15 anos, são devido a lesões nas faces proximais de molares e pré-molares. Ou seja, exatamente nos locais onde o fio dental é eficaz na remoção de placa bacteriana.

Também é importante salientar que não se vê com facilidade em supermercados e drogarias o limpador lingual à venda. Normalmente se acha em dentais todas as marcas comerciais, mas isso é uma situação contrária à promoção da saúde, pois esse tipo de estabelecimento comercial é direcionado aos profissionais de odontologia e não à população de um modo geral.

Com esse distanciamento da população, é natural que muitos nunca tenham visto um limpador lingual, e considerando a deficiência de informação que existe sobre esse assunto, talvez mesmo vendo-os não saberiam do que se trata.

Verificamos somente que em relação ao acesso a produtos de higiene oral, existe uma diferenciação. Os adolescentes dos estratos mais privilegiados economicamente utilizam 
enxaguatórios bucais, escovas específicas para limpeza interdental e fio dental com freqüência.

M. Bochecho com Cepacol, passo fio dental e escovo os dentes. E no aparelho, eu passo passa-fio (Feminino - 13 anos: estrato médioalto).

T. Eu escovo os dentes, passo fio dental, escovo a língua e uso Listerine (Feminino -14 anos: estrato alto).

Existem fortes evidências científicas de uma associação positiva entre o nível socioeconômico e saúde. Isto quer dizer que o gradiente social se reproduz na saúde das pessoas. Assim sendo, as pessoas mais privilegiadas economicamente apresentam uma saúde melhor (MERCENES; BÖNECKER, 2000). Considerando esta informação, é possível relacionar o acesso aos produtos odontológicos, com a qualidade de saúde bucal dos adolescentes, pois estes ainda têm um custo impeditivo para os que possuem menos recursos.

Finalizando, a adolescência em si é uma fase de grande mudança. Mudança de um mundo infantil, no qual há a proteção do seio familiar e onde todos são conhecidos, para o universo adulto, extenso e desconhecido.

No intuito de minimizar os obstáculos desta caminhada, acreditamos que deva ser considerada a presença de halitose um fator de interferência na qualidade de vida, pois se o aspecto do bem-estar material que aborda as finanças e renda estiver prejudicado, os adolescentes não poderão ter o acesso igualitário aos métodos e procedimentos de higiene oral que comprovadamente reduzem a freqüência deste problema.

Assim como devemos considerar o desenvolvimento e atividades, pois este aspecto aborda a competência, escolha e controle. Situações necessárias para se que possa praticar o autocuidado. 


\section{Promoção de saúde como caminho para a qualidade de vida}

Cada ato nosso, por mais simples que seja, está afetando a existência do todo em seus planos mais sutis.

(CAPRA,1996) 


\section{PROMOÇÃO DA SAÚDE COMO CAMINHO PARA QUALIDADE DE VIDA}

Finalizando, refletimos que as temáticas: halitose como um problema para o adolescente e cuida da sua boca senão vai levar um fora, apesar de abordarem diferentes aspectos, todos de alguma forma afetam de forma significativa a qualidade de vida.

Considerando a conceituação de qualidade de vida de Felce e Perry (1996) citada em nosso referencial, pudemos concluir que todos os núcleos de sentido abordam a qualidade de vida, cada um sob um diferente ângulo. Ou seja, a halitose pode comprometê-la de diferentes formas.

No aspecto do bem-estar emocional citado pelos autores, são considerados necessários à qualidade de vida o pensamento positivo, amor próprio, respeito e sexualidade. Pudemos analisar por intermédio dos núcleos de sentido: “boca de bueiro”, “sai de perto” e "namoro” que tais fatores se encontram prejudicados pela halitose.

Pois, no núcleo de sentido "boca de bueiro" foi abordado o significado da halitose e como os adolescentes vêem quem possui o problema, possibilitando a teorização sobre aspectos centrais característicos da adolescência como a auto-imagem e auto-estima. Assim como, também verificamos no núcleo de sentido "sai de perto” o processo de estigmatização que ocorre por meio de segregação de quem possui o problema.

E no núcleo de sentido "namoro", abordamos a sexualidade vivida nos namoros adolescentes que se mostrou comprometida na presença de halitose.

Já o aspecto do bem-estar social aborda as relações pessoais, amigos, vida social, envolvimento na comunidade, aceitação e apoio. Fatores que também são afetados pela halitose.

Pudemos fazer esta afirmação baseando-se no núcleo de sentido: “ela não se toca que tem mau-hálito?”, pois este reflete a interferência da halitose nas experiências de vivência em grupo, nas relações sociais e na comunicação interpessoal. 
Importante ressaltarmos que em relação ao gênero, não notamos diferença nas falas dos meninos e das meninas. Em todos os núcleos de sentido, existiu uma homogeneidade em relação aos assuntos tratados.

Já no que diz respeito ao bem-estar material, que aborda as finanças e renda, podemos afirmar que os estratos sociais menos privilegiados possuem menor acesso aos recursos disponíveis para a prevenção da halitose. O que pode ser verificado no núcleo de sentido “como enfrenta”.

Entre outros aspectos, discutimos que os produtos de higiene oral ainda apresentam um custo impeditivo, e que limpadores linguais não são encontrados com facilidade em locais populares.

Quando Felce e Perry (1996), em sua conceituação sobre qualidade de vida, citam o desenvolvimento e atividades, reportam que são necessários à qualidade de vida a competência, a independência, controle, trabalho e educação. Fatores que foram abordados no núcleo de sentido “conhecimento”, “sai de perto” e também no “como enfrenta”.

Quando citavam os prejuízos que a halitose poderia causar nas relações de trabalho, existiu diferença entre os estratos sociais. Sendo esta preocupação mais presente nos estratos menos privilegiados economicamente.

Ponderando sobre qualidade de vida, naturalmente emerge o conceito de promoção de saúde, pois esta objetiva a melhoria da qualidade de vida das pessoas, e é um processo que confere às populações os meios de assegurarem um maior controle sobre sua própria saúde e de como melhorá-la, visa à igualdade em matéria de saúde.

Suas intenções têm por meta reduzir diferenças atuais que caracterizam o estado de saúde, e oferecer a todos os indivíduos os mesmos recursos e possibilidades para realizarem plenamente o seu potencial de saúde. Isto compreende uma base segura, num ambiente 
sustentável, com acesso às informações, com o desenvolvimento de aptidões e com possibilidades que permitam fazer escolhas sadias.

O conceito de promoção da saúde é marcado pelo processo histórico de reconhecimento das limitações da abordagem tradicional em lidar com o processo saúde/doença e de mudança na compreensão dos determinantes de saúde, ampliando a importância das condições de vida para a realização da saúde.

Capra (1996) avalia que quanto mais estudamos nossos problemas, somos levados a perceber que eles não podem ser entendidos isoladamente. São interligados, sistêmicos e interdependentes.

Ao pensarmos em saúde coletiva, naturalmente se encontram diversas áreas do saber que devem trabalhar de forma renovada, em uma lógica recíproca, cíclica, ordenada e capaz de se auto-sustentar.

Ao falarmos de interligação entre diferentes áreas do saber, naturalmente aparecem os termos multi, pluri e interdisciplinar. Piaget (1972) esclarece que a transdisciplinaridade seria o último estágio das possibilidades de relações disciplinares a ser atingido, onde não haveria somente relações ou reciprocidades, mas ligações se situariam num plano total, sem fronteiras entre as disciplinas.

Etimologicamente a palavra saúde origina-se do latim salus que significa são, inteiro, salvo, salvação. Dessa palavra derivam: saluus, solidus e soldus, que significa solda e soldado, quer dizer o que é uma única peça, inteiro, completo. Em suas origens gregas, o significado entre outros é inteiro, intacto, real, em suma, integridade. Vista deste aspecto, a saúde como integridade não permite fragmentação em saúde física, mental e social, portanto parte-se de uma visão holística que em tese supõe entendê-la na interface de uma grande diversidade de disciplinas (NUNES, 1995, p.107).

Considerando saúde e qualidade de vida de forma mais abrangente, acreditamos que a transdisciplinaridade entre as áreas de saúde, como também a relação com a estrutura maior, promovida por intermédio da promoção da saúde, levaria à solução de muitas questões da área de saúde que ainda são vistas através das lentes do modelo biomédico. Dessa forma, para 
cuidarmos de forma integral de um paciente, necessitamos de uma perspectiva holística que a visão de mundo cartesiana não nos oferece.

O termo holístico refere-se a uma compreensão da realidade em função de totalidades integradas cujas propriedades não podem ser reduzidas a unidades menores (CAPRA, 1982). A visão holística transcende as atuais fronteiras disciplinares e conceituais.

É importante compreender a complexidade que se desenvolve nos processos de criação, reprodução e transformação de estratégias a partir do ponto de vista dos atores sociais envolvidos nestas relações, pois de modo geral a formação nas faculdades ainda tem privilegiado o modelo cartesiano e biomédico em suas estruturas de ensino, que posteriormente são reproduzidas pelos profissionais oriundos destas. No entanto, se alianças forem realizadas através de inter-relações, novas habilidades poderão ser apreendidas.

Sheiham e Moysés (2000) afirmam que promoção da saúde bucal é um conceito que transcende a dimensão meramente técnica do setor odontológico, é um conceito que implica na incorporação da dimensão política e social como aspectos essenciais, integrando a saúde bucal às demais práticas de saúde coletiva, assim como, também o desenvolvimento e a manutenção de relações com universidades, associações profissionais e clínicos do setor público, privado e filantrópico local.

Ferriani (1991) já alertava em seu livro “a inserção do enfermeiro na saúde escolar”, que a sistematização realizada no atendimento odontológico dos escolares de Ribeirão Preto gera a fragmentação de programas, pois a classe odontológica atua de forma isolada, paralela, divergente quanto à filosofia, sem entrosamento e objetivos comuns.

Sheiham e Moysés (2000) sugerem como medidas para alavancar o compromisso e o estímulo de dentistas, o encorajamento destes a integrarem-se no trabalho com a equipe geral de saúde, a socialização e popularização da prática odontológica e a utilização de procedimentos de formação para estudantes de odontologia que enfatizem a habilidade de se 
ocupar de atividades não-clínicas como uma parte importante do seu trabalho futuro.

A promoção da saúde pode ser realizada em qualquer espaço social, onde exista potencial para melhorar as condições de saúde. Escolas, por exemplo, podem desenvolver uma política de alimentação, oferecendo na cantina alimentos saudáveis, a inclusão de tópicos de saúde bucal no currículo, disponibilidade de lugares adequados para higienização, provisão de treinamento para professores e funcionários em tópicos de saúde bucal, estratégias para controlar acidentes nas escolas e a aproximação da comunidade por meio da ampliação das relações com os pais (MOYSÉS; WATT, 2000).

Os autores ainda complementam que, por intermédio de alianças entre o setor da saúde e outros profissionais, tais como professores e líderes comunitários, programas de saúde bucal podem ser construídos para grupos específicos da população em ações coletivas locais para a saúde. E que preparação para planejamento, avaliação e pesquisa são necessários para compreender as necessidades de pessoas, definir prioridades e monitorar o impacto das atividades realizadas.

A mudança deve acontecer no sentido de não mais tratar pacientes e sim promover saúde de pessoas; a orientação, a prevenção e a identificação precoce de possíveis enfermidades já instaladas são em odontologia meios comprovadamente eficazes para se obter saúde. Partindo deste princípio sabemos que no processo saúde/doença é importante termos um equilíbrio dinâmico, envolvendo os aspectos físicos e psicológicos do organismo, assim como suas interações com o meio ambiente natural e social. O laço que une os indivíduos ao seu ambiente constitui a base de uma aproximação socioecológica da saúde.

Para que haja a promoção da saúde, deve-se ter a participação popular no processo de saúde, visando à mudança de comportamento, em abordagens capacitadoras e facilitadoras, o que acreditamos ser possível por meio da educação em saúde. Sob a ótica da promoção da saúde, defini-se o termo "autocuidado" como o conjunto de ações e decisões tomadas pelo 
indivíduo, com a finalidade de prevenir, diagnosticar e tratar qualquer desvio de sua própria saúde (BUISCHI e AXELSSON, 1997).

Considerando os ensinamentos de Freire (1993) de que a educação não é neutra, e ocorre no contexto de vida das pessoas, devemos encorajar a população a questionar os problemas do seu dia-a-dia, levá-los a participar das decisões e finalmente possibilitando que se tornem capazes de realizar coisas, ou seja, o autocuidado.

Desde 1978, a OMS e a UNICEF já preconizam que nos cuidados primários com a saúde deve ser incluída a educação em saúde, e que estas deveriam ser coordenadas com os outros setores sociais, culturais e econômicos. Reforçar a ação comunitária, desenvolver habilidades pessoais e criar entornos favoráveis à saúde são também pressupostos sobre os quais a promoção da saúde pode se realizar (MENDES, 1996).

Diante de todos esses conceitos, esperamos que a situação representada na pequena história abaixo, não torne a se repetir na área da saúde. Uma maior ênfase em promoção da saúde é voltar a atenção para a margem superior do rio.

Rio acima - rio abaixo!

“Lá estou eu, na margem inferior de um rio caudaloso, quando ouço o grito de uma pessoa se afogando. Eu pulo para dentro do rio, ponho meus braços ao redor desta pessoa, puxo-a para a margem e aplico respiração artificial. No momento em que ela começa a respirar, ouço outro grito por ajuda. Imediatamente, eu pulo para dentro do rio, encontro aquele que pede por socorro, puxo-o para a margem, aplico respiração artificial, e então, logo que ele começa a respirar, ouço outro grito de ajuda. Dentro do rio novamente indefinidamente, a cena se repete. Sabe, eu estou tão ocupado pulando para dentro do rio, puxando-os para a margem, aplicando respiração artificial, que não tenho tempo para ver quem, afinal está na margem superior empurrando-os para dentro do rio”

(McKinlay, $1974^{15}$ apud MOYSES; WATT, 2000, p.11)

${ }^{15}$ MCKINLAY, J. A case for refocusing upstream: the political economy of illness. In Proceeding of the American Heart Association. Conference on applying behavioural sciences to cardiovascular risk. Seattle, 1974. p.7-17. 
Diante de todo o exposto, acreditamos que a pesquisa atingiu o objetivo a que se propôs, que foi: compreender como a halitose é vivenciada entre adolescentes e os reflexos na sua qualidade de vida. E que por intermédio de nossos resultados pudemos responder às nossas questões e pressupostos.

Verificamos que a halitose realmente prejudica os relacionamentos interpessoais dos adolescentes, impondo uma barreira entre estes e a turma. Assim como compromete a vivência da sexualidade na adolescência.

E que existe pouca informação a respeito deste problema, o que impede que seja realizada a sua prevenção de forma adequada.

Dessa forma, concluímos que a halitose pode limitar a qualidade de vida dos adolescentes, em vários aspectos, situação que poderia ser prevenida, tratada e, principalmente, orientada por meio de ações educativas, integradas em um processo de promoção de saúde que contemplasse diversas áreas de atuação. 


\section{Considerações finais}

“Ao término de um período de decadência sobrevém o ponto de mutação. A luz poderosa que fora banida ressurge. Há movimento, mas este não é gerado pela força... O movimento é natural, surge espontaneamente. Por essa razão, a transformação do antigo torna-se fácil. $O$ antigo é descartado, e o novo é introduzido. Ambas as medidas se harmonizam com o tempo, não resultando daí, portanto nenhum dano" (I Ching chinês - o livro das mutações) 


\section{CONSIDERAÇÕES FINAIS}

Este estudo teve por objetivo geral compreender como a halitose é vivenciada entre adolescentes e os reflexos na sua qualidade de vida. E como objetivos específicos: identificar os significados atribuídos pelos adolescentes à halitose e às pessoas que vivenciam tal problema; identificar o conhecimento que os adolescentes têm sobre a halitose e de quais meios que se utilizam frente a mesma e analisar os reflexos da halitose entre adolescentes na sua qualidade de vida.

Assim, retomaremos alguns pontos abordados neste estudo. Realizamos uma construção histórico-social sobre a halitose que também abordou aspectos de sua fisiopatologia, o que nos auxiliou no entendimento de algumas questões que levaram à proposta desta pesquisa.

A relação dos odores bucais com os aspectos sociais sempre foi um fator de preocupação para a sociedade que, procurando mascará-los, se utilizava de diversos artifícios e substâncias. O mau odor bucal sempre foi, e ainda é, um obstáculo para a plenitude da vivência conjugal.

Sendo a halitose um distúrbio que acompanha a sociedade há muitos anos, revela-se inaceitável que, com o avanço dos conhecimentos, estes não sejam transmitidos de forma adequada para a população.

Em nosso referencial teórico, foram abordadas características da adolescência, particularidades desta fase que tornam os adolescentes mais vulneráveis aos problemas causados pela halitose. Também contemplamos conceitos sobre qualidade de vida.

Tais temas nos auxiliaram a realizar uma discussão mais profunda e coerente com nossa visão de saúde. 
Em relação ao caminho metodológico adotado, o qualitativo mostrou-se adequado às nossas necessidades, porque permitiu captar sentimentos não mensuráveis por meio de técnicas quantitativas.

Ante o exposto, encontramos nas temáticas: "Halitose como um problema para o adolescente” e “Cuida da sua boca senão vai levar um fora” elementos que responderam aos nossos pressupostos de que esta patologia limita a qualidade de vida de adolescentes.

E como consideramos a promoção da saúde um modo de se obter qualidade de vida, sugerimos a educação em saúde como meio para atingir este objetivo.

Assim como é necessária a integração entre as áreas de saúde, e destas com as dimensões políticas e sociais. E também o desenvolvimento e a manutenção de relações com universidades, associações profissionais e clínicos do setor público, privado e filantrópico local.

Deixamos como sugestões:

- Incentivo à educação em saúde bucal nas escolas, por meio dos dentistas presentes nestas, considerando sempre uma visão ampla do conceito saúde.

- Organizar um mecanismo de educação continuada por meio dos profissionais de odontologia, como: dentistas, auxiliares odontológicos e técnicos em higiene dental, a ser realizado nas escolas que não possuam dentista.

- Utilizar o mecanismo supracitado para familiares dos adolescentes, por meio de encontros que possam ter também outros atrativos no intuito de motivar a presença.

- Reforçar a orientação em relação à necessidade de limpeza da língua e sua ligação com a halitose.

- Integração multiprofissional, pois como a halitose pode ser multifatorial, é importante que os dentistas, ao diagnosticar que já foram eliminados todos os fatores relacionados à competência odontológica, encaminhem o paciente ao profissional capacitado. 
- Assim como é importante que os médicos encaminhem o paciente ao dentista. Pois como a etiologia dessa patologia se encontra basicamente na boca, é necessário que o dentista realize o diagnóstico correto.

- Realização do trabalho em conjunto com psicólogos quando for diagnosticada a presença de halitose psicológica.

- Integração com as universidades e entidades de classe.

Considerando que tais resultados são transitórios e mutáveis, acreditamos ter lançado uma semente que pode germinar em novos e maiores conhecimentos. 
Referências 


\section{REFERÊNCIAS}

ABERASTURY, A. Adolescência normal. Tradução Suzana Maria Garagoray Balve. Porto Alegre: Artes Médicas, 1981. 92p.

ACKERMAN, D. Uma história natural dos sentidos. Rio de Janeiro: Editora Bertrand Brasil s/a, 1992. 366p.

ANDRADE LIMA, T. Humores e odores: ordem corporal e ordem social no Rio de Janeiro, século XIX. História, Ciências, Saúde - Manguinhos, v.2, n.3, p.44-96, 1996.

ARATANGY, L.R. Sexualidade: a difícil arte do encontro. São Paulo: Editora Ática, 1996. 159p.

ARGYLE, M. Bodily communication. Madison, Conn.: International Universities Press, 1990. 363p.

ASHLEY, F.P. Role of dental health education in preventive dentistry. In: ROSS, C. (leader). Health through oral health. London: Quintessence, 1989. p. 406-414.

AXELLSON, P. et al. The effect of a new oral hygiene training program on approximal caries in 12-15 year old Brazilian children: results after three years. Adv. Dental Research. v.8, p.278-284, 1994.

AYERS,K.M.S; COLQUHOUN, A.N.K. Halitosis: causes, diagnosis, and treatment. New Zealand Dental Journal, v. 94, p.156-160, 1998.

BARDIN, L. Análise de conteúdo. Lisboa: Edições 70, 1979.

BELLINI, H.T.; ARNENBERG, P.; von der FEHR, F. Oral hygiene and caries. Acta Odontol Scand, v.39, p.257-263, 1981.

BERSCHEID, E. Atração interpessoal. Tradução Dante de Moreira Leite. São Paulo: Editora da Universidade de São Paulo, 1973. 132p.

BOFF, L. Princípio de compaixão e cuidado. Tradução Carlos Almeida Pereira. Petrópolis: Vozes, 2000. 164p. 
BOSY, A. Oral malodor: philosophical and practical aspects. J. Canadian Dental Association, v.63, n.3, p. 196- 201, 1997.

BRADLEY, R.M. Fisiologia oral básica. Tradução Wilson Abrão Saad e Luiz Antônio de Arruda Camargo. São Paulo: Panamericana, 1981. 198p.

BREW, M.C.; PRETTO, S.M.; RITZEL, I.F. Erupção dos dentes. In: Odontologia na adolescência: uma abordagem para pais, educadores e profissionais de saúde. Porto Alegre: Mercado Aberto, 2000. p. 11-20.

BRIGGS, D.C. A auto-estima de seu filho. Tradução Waltensir Dutra. São Paulo: Martins Fontes, 2000. 211p.

BUISCHI, Y. P.; AXELSSON, P. Controle mecânico da placa dental realizado pelo paciente. In: KRIGER, L. (org.). Promoção de saúde bucal. São Paulo: Artes Médicas, 1997. p.113127.

CAHEN, G. O beijo: primeiras lições de amor - história, arte e erotismo. Tradução Ana Matilde de Mesquita Sampaio. São Paulo: Mandarim, 1998. 207p.

CAMPOS, C.A.H.; COSTA, H.O.O. Tratado de otorrinolaringologia. São Paulo: Roca, 2002. v. 1.1180 p.

CAPRA, F. O ponto de mutação. Tradução de Álvaro Cabral. São Paulo: Cultrix, 1982. 447p.

. A teia da vida: uma nova compreensão científica dos sistemas vivos. Tradução de Newton Roberval Eichemberg. São Paulo: Cultrix, 1996.

CASAS, F. La situaciones de cuidado de la infancia de 6 a 12 años de las comarcas de Girona. Universitat de Barcelona, 1996.

CAVALCANTI, R.C. Adolescência. In: VITIELLO, N. et al. Adolescência hoje. São Paulo: Roca, 1988. p. 5-27.

CHEN, M.; HUNTER, P. Oral health and quality of life in New Zealand: a social perspective. Soc Sci Med, Oxford, v.43, n.8, p.1213-1222,1996. 
CLASSEN, C.; HOWES, D.; SYNNOTT, A. Aroma: a história cultural dos odores. Tradução de Álvaro Cabral. Rio de Janeiro: Jorge Zahar Ed., 1996. 262p.

CODERP - Companhia de Desenvolvimento de Ribeirão Preto. Disponível em: <http://www.coderp.com.br>. Acesso em: 27 de abril de 2006.

COSTA, M. Sexo o dilema do homem: força e fragilidade. São Paulo: Editora Gente, 1993. 211p.

DAVIS, F. A comunicação não-verbal. Tradução Antônio Dimas. São Paulo: Summus, 1979. 196p.

DeBIASE, C. B. Dental health education: theory and pratice. Pennsylvania: Lea \& Febiger, 1991. 314p.

De BOEVER, E.H.; LOESCHE, W.J. Assessing the contribution of anaerobic microflora of tongue to oral malodor. JADA, v. 126, Oct, p.1384-1393, 1995.

DELANGUE, G. et al. An invetory of patientes'response to treatment at a multidisciplinary breath odor clinic. Quintessence Internacional, v.30, n.5, p.307-310, 1999.

DEMO, P. Introdução à metodologia da ciência. São Paulo: Atlas, 1987. 118p.

DONAS, S. Marco Epidemiológico-Conceptual da Saúde Integral do Adolescente. Organização Pan-Americana da Saúde. Brasil, 1992. 19p.

ELIAS, M.S. Importância da saúde bucal para adolescentes de diferentes estratos sociais de Ribeirão Preto. 2000. 158p. Dissertação (Mestrado em Enfermagem em Saúde Pública) Escola de Enfermagem de Ribeirão Preto, Universidade de São Paulo, Ribeirão Preto, 2000.

FAYERS, P.M.; MACHIN, D. Quality of life: assessment, analyses and interpretation. Baffins Lane, Chichester, John Wiley \& Sons Ltd, 2000. 416 p.

FELCE, D.; PERRY, J. Exploring current conceptions of quality of life. In: RENWICK, R.; BROWN, I.; NAGLER, M. Quality of life in health promotion and rehabilitation: conceptual approaches, issues, and applications. California: Sage publications, 1996. p. 51-62. 
FERRIANI, M.G.C. A inserção do enfermeiro na saúde escolar. São Paulo: Editora da Universidade de São Paulo, 1991. 212p.

FIERRO, A. Desenvolvimento da personalidade na adolescência. In: COLL, C.; PALÁCIOS, J.; MARCHEZI, A. Desenvolvimento psicológico e educação: psicologia evolutiva. Tradução Marcos A. G. Domingues, Porto Alegre: Artes Médicas, 1995. p. 288-298.

FREIRE, P. Que fazer: teoria e pratica em educação popular. Petrópolis-RJ: Vozes, 1993. 68p.

FREUD, S. Obras Completas - Vol. IV - A Interpretação dos Sonhos. Tradução de Jaime Salomão. Rio de Janeiro: Imago, 1972.

GAÍVA, M.P.M. Qualidade de vida e saúde. Rev Enferm UERJ . v.6, n.2, p. 377-382, 1988.

GALHARDO, M.C. Avaliação química e instrumental dos pacientes com queixa subjetiva de halitose. 2002. 37p. Dissertação (mestrado) - Faculdade de Medicina de Ribeirão Preto, Universidade de São Paulo, Ribeirão Preto. 2002.

GAUDERER, E. C. Sexo e sexualidade da criança e do adolescente. Rio de Janeiro: Editora Rosa dos tempos, 1996. 271p.

GEORGE, A.L. Quantitative and qualitative approaches to content analysis. In: SOLA POOL. Trends in content analysis, Urbana: University of Illinois Press, 1959. p. 7-32.

GOFFMAN, E. Estigma: notas sobre a manipulação da identidade deteriorada. Rio de Janeiro: Editora Zahar, 1982. 158p.

GOLDENBERG, M. A arte de pesquisar. Rio de Janeiro: Ed. Record, 2002. 107p.

GRAMSCI, A. Cartas do cárcere. Rio de Janeiro: Civilização Brasileira, 1978.

GUYTON, A. C. Fisiologia humana. Tradução Charles Alfred Ésberard. Rio de Janeiro: Guanabara, 1985. 564p.

HEIDEGGER, M. Ser e tempo. Tradução Márcia de Sá Cavalcante. Petrópolis: Vozes, 2001. 325p. 
HINE, M.K. Halitosis. The Journal of American Dental Association. v.55, p. 37-46, Jul. 1957.

INTERSCAN CORPORATION. Disponível em: <http:// www. gasdetection. com /halimtr.htm. Acesso em: 19 de agosto de 2004.

JERSILD, A. T. Psicologia da adolescência. São Paulo: Nacional, 1971. 596 p.

JOHNSON, P.W.; LANCERO, H. Function of gingival fibroblasts and periodontal ligament cells in the presence of methyl mercaptan. Quintessence International, v.30, n.5, p.343-349, 1999.

KLEINBERG, I.; WESTBAY, G. Salivary and metabolic factors involved in oral malodor formation. J. Periodontol. v.63, n.9, p. 768-775, sep. 1992.

KOLBE, A.C. Kolbe: mau hálito. Disponível em: <http://www.svn.com.br/kolbe/>. Acesso em: 30 de agosto de 2000.

KWON, H.S.; GUEDES-PINTO, A.C. Em crianças. In GUEDES-PINTO, A.C. Higiene bucodental em odontopediatria. São Paulo: Santos, 2003. p. 491-509.

LAPLANTINE, F. Aprender antropologia. São Paulo: Brasiliense, 1991. 205p.

LASCALA, N.T.; MOUSSALLI, N.H. Higienização Bucal. In: LASCALA, N.T. Compêndio terapêutico periodontal. São Paulo: Artes Médicas, 1993. p. 240-272.

LE BRETON, D. Anthropologie du corps et modernité. Paris: PUF, 1990.

LERMAN, S. Historia de la Odontologia: y su ejercicio legal. Buenos Aires: El Ateneo, 1942. 332p.

LEVI-STRAUSS, C. Aula Inaugural: desvendando máscaras sociais. Rio de Janeiro: Ed. Francisco Alves, 1975.

LITTLEJOHN, J. Estratificação social: uma introdução. Tradução Ricardo Gomes Lima. Rio de Janeiro: Zahar editores, 1976. 179p. 
LITTLEJOHN, S.W. Fundamentos teóricos da comunicação humana. Tradução Álvaro Cabral. Rio de Janeiro: Zahar editores, 1982. 407p.

LOESCHE, W. The effects of antimicrobial mouthrinses on oral malodor and their status relative to US Food and Drug Administration regulations. Quintessence Internacional, v.30, n.5, p.311-318, 1999.

LOESCHE, W.J.; De BOEVER, E.H. Estratégias para identificar os principais determinantes microbianos do mau hálito. In: ROSENBERG, M. Halitose: perspectivas em pesquisa. Rio de Janeiro: Guanabara Koogan, 2003. p. 26-34.

LU, D.P. Halitosis: an etiologic classification, a treatment approach, and prevention. Oral Surgery, Oral Medicine and Oral Pathology, v.54, n.5, p.521-526, Nov. 1982.

MANDEL, I.D. Antimicrobial mouthrinses: overview and uptade. J. Am. Dent. Assoc., v.125 (Special Issue), p.2-10, 1994.

MARTIN, A.J.; STOCKLER, M. Quality of Life assessment in health care research and pratice. Evaluation \& Health professions. v. 21, n.2, p.141-156. 1998.

MASLOW, A.H. Motivation and personality. New York : Harper \& Row, 1970. 369 p.

MEEBERG, G.A. Quality of life: a concept analysis. J Adv Nurs. v.18, p.32-38, 1993.

MENDES, I.J.M. Promoção de saúde: caminhando para o único. 1996. 175p. Tese (livredocência) - Escola de Enfermagem de Ribeirão Preto, Universidade de São Paulo. Ribeirão Preto, 1996.

MENINGAUD, J.P. et al. L'Halitose en 1999. Rev. Stomatol. Chir. Maxillofac, v.100, n.5, p.240-244, 1999.

MERCENES, W.; BÖNECKER, M.J.S. Aspectos epidemiológicos e sociais das doenças bucais. In: BUISCHI, Y. P. Promoção de saúde bucal na clínica odontológica. São Paulo: Artes Médicas, 2000, p.72-98.

MCKINLAY, J. A case for refocusing upstream: the political economy of illness. In Proceeding of the American Heart Association. Conference on applying behavioural sciences to cardiovascular risk. Seattle, 1974. p.7-17. 
MINAYO, M.C.S. O desafio do conhecimento: Pesquisa qualitativa em saúde. São Paulo: Hucitec, 1996. 269p.

2001. 80p.

Pesquisa social: teoria, método e criatividade. Rio de Janeiro: Vozes,

MINAYO, MCS, DESLANDES. Caminhos do pensamento: epistemologia e método. Rio de Janeiro: Editora Fiocruz, 2002. 379p.

MINAYO, MCS; HARTZ, Z.M.A.; BUSS, P.M. Qualidade de vida e saúde: um debate necessário. Ciência \& Saúde Coletiva. v.5, n.1, p. 7-18, 2000.

MOYSÉS, S. T.; WATT, R. Promoção de saúde bucal: definições. In: BUISCHI, Y. P. (org.) Promoção de saúde bucal na clínica odontológica. São Paulo: Artes Médicas, 2000. p.0122.

NEIDERS, M.; RAMOS, B. Operation of bad breath clinics. Quintessence Internacional, v.30, n.5, p.295-301, 1999.

NORDENFELT, L. Concepts and measurements of quality of life in health care. Dordrecht: Kluwer, 1994. 283p.

NUCCI, N.A.G. Qualidade de vida e câncer: um estudo compreensivo. 2003. 225p. Tese (Doutorado) - Faculdade de Filosofia, Ciências e Letras de Ribeirão Preto, Universidade de São Paulo, Ribeirão Preto, 2003.

NUNES, E.D. A questão da interdisciplinaridade no estudo da saúde coletiva e o papel das ciências sociais. In: CANESQUI, A.M. (org.) Dilemas e desafios das ciências sociais na saúde coletiva. São Paulo: Hucitec-Abrasco, 1995. p.95-113.

ORGANIZAÇÃO MUNDIAL DA SAÚDE. Saúde reprodutiva de adolescentes - Uma estratégia para a ação. Genebra, 1989. 21p.

OPPERMANN, R.V.; RÖSING, C.K Prevenção e tratamento das doenças periodontais In: KRIGER, L. (org.) Promoção de saúde bucal. São Paulo: Artes Médicas, 1997. p. 256-281.

OSÓRIO, L.C. Adolescente hoje. Porto Alegre: Artes Médicas, 1992. 103p. 
OSTENFELD, E. Aristotle on the good life and quality of life. In. Nordenfelt, L. Concepts and measurement of quality of life in health care. Dordrechet: Kluwer, 1994. p. 19-34.

OUTEIRAL, J.O. Adolescer: estudo sobre a adolescência. Porto Alegre: Artes Médicas, 1994. 95p.

PALÁCIOS, J. O que é adolescência. In: COLL, C.; PALÁCIOS, J.; MARCHEZI, A. Desenvolvimento psicológico e educação: psicologia evolutiva. Tradução Marcos A. G. Domingues, Porto Alegre: Artes Médicas, 1995. p. 263-271.

PEREIRA, C.A.A Um panorama histórico-cultural acerca das subdimensões de qualidade de vida e bem-estar subjetivo. Arq. Bras. de Psicologia. v.49, n.4, p. 32-48, 1998.

RAWSON, N.E. Cells and molecular biology of olfaction. Quintessence International, v.30, n.5, p.335-341, 1999

PÉREZ GOMES, A.I. A cultura escolar na sociedade neoliberal. Tradução Ernani Rosa. Porto Alegre: Artmed editores, 2001. 320p.

PETER, J. P. L`imaginaire des maladies: histoire et imaginaire. Paris: Poiesis-Payot, 1986.

PIAGET, J. Epistemología de las ciencias humanas. Tradução Hugo Acevedo. Buenos Aires: Proteo. 1972. 218p.

POLO, M. As viagens: Marco Pólo. Tradução Ivone Castilho Benedetti. São Paulo: Martins Fontes, 1997. 240p.

RAPPAPORT, C. Encarando a adolescência. São Paulo: Ática, 1997. 111p.

RAPHAEL, D. Quality of life and adolescent health. In: RENWICK, R.; BROWN, I.; NAGLER, M. Quality of life in health promotion and rehabilitation: conceptual approaches, issues, and applications. California: Sage publications, 1996. p. 307-324.

RAWSON, N.E. Cells and molecular biology of olfaction. Quintessence International, v.30, n.5, p.335-341, 1999. 
REINGEWIRTZ et al. Mechanical effects and volatile sulfur compound-reducing effects of chewing gums: comparison between test and base gums and control group. Quintessence International, v.30, n.5, p. 319-323, 1999.

RIBEIRÃO PRETO. Prefeitura Municipal. Disponível em: <http://www.saude.ribeiraopreto. sp.gov.br>. Acesso em 29 de agosto de 2006.

RIBEIRO, R.P.P. Indicadores de hábitos dietéticos e aspectos cognitivos e comportamentais relacionados aos distúrbios de conduta alimentar em adolescentes do sexo feminino. 1998. 98p. Tese (Doutorado) - Faculdade de Medicina de Ribeirão Preto, Universidade de São Paulo, Ribeirão Preto, 1998.

RICHARDSON, R. J. et al. Pesquisa social: métodos e técnicas. São Paulo: Atlas, 1999. 334p.

RING, M.E. História da Odontologia. Tradução Fernando Gomes do Nascimento. São Paulo: Manole, 1998. 370p.

RODRIGUES, J.C. Tabu do corpo. Rio de Janeiro: Dois pontos, 1986.

RODRIGUES, N. Da mistificação da escola à escola necessária. São Paulo: Cortez, 1996. 97p.

ROSENBERG, M. et al. Self-assessment of oral malodor 1 year following initial consultation. Quintessence International, v.30, n.5, p.324-327, 1999.

ROSENBERG, M. Halitose: perspectivas em pesquisa. Rio de Janeiro: Guanabara Koogan, 2003. 173p.

ROSENTHAL, E. Os dentes e o folclore no Brasil. São Paulo: Ysayama, 1998. 95p.

SALVADOR, S.L.; FIGUEIREDO, L. Halitose. In: OPPERMANN, R.V. e RÖSING, C.K. (org.). Periodontia: ciência e clínica. São Paulo: Artes Médicas, 2001. p.267-274.

SANZ, M.; ROLDÁN. S.; HERRERA, D. Fundamentals of Breath Malodour. J Contemp Dent Pract, v.2, n.4, p.1-17, nov. 2001.

SAYÃO, R. Sexo é sexo. São Paulo: Companhia das Letras, 1997. 188p. 
SEEMANN, R. et al. Effectiveness of mechanical tongue cleaning on oral levels of volatile sulfur compounds. JADA, v.132, n.9, p.1263-7, sep, 2001.

SEGER, L. Psicologia e Odontologia: uma abordagem integradora. São Paulo: Santos, 1988. $165 p$.

SHEIHAM, A.; STEELE, J.G.; MARCENES, W.; TSAKOS, G.; FINCH, S.; WALLS, A.W. Prevalence of impacts of dental and oral disorders and their effects on eating among older people; a national survey in Great Britain. Community Dent Oral Epidemiol. v.29, n.3, p.195-203, 2001.

SHEIHAM, A.; MOYSÉS, S. J. O papel dos profissionais de saúde bucal na promoção de saúde. In: BUISCHI, Y. P. Promoção de saúde bucal na clínica odontológica. São Paulo: Artes Médicas, 2000, p.23-37.

SORENSON, R. Youth's need for challenge and place in American society: its implications for adults and adult institutions. Washington: National Committee for Children and Youth Inc, 1962.

STEFANELli, M.C. Comunicação com o paciente: teoria e ensino. São Paulo: Robe editorial, 1993. 200p.

SULLIVAN, C. Searching for nineteenth-century Florida Water bottles. Historical Archaeology, v.28, n.1, p.78-98, 1994.

SUPLICY, M. Conversando sobre sexo. Rio de Janeiro: Vozes, 1983. 367p.

SUZUKI, K. Pesquisa sobre qualidade de vida de pacientes de UTI: uma revisão de literatura. 2002. 101p. Dissertação (Mestrado em Enfermagem) - Escola de Enfermagem, Universidade de São Paulo, 2002.

TAVARES, M.C.G.C.F. Imagem corporal: conceito e desenvolvimento. Barueri (SP): Manole, 2003. 150p.

TÁRZIA, O. Halitose. Rio de Janeiro: Publicações Científicas, 2003. 226p.

THYLSTRUP, A Tratado de cariologia, Tradução Sergio Weyne. São Paulo: Artes Médicas, 1988. 388p. 
TIBA, I. Adolescência: o despertar do sexo - um guia para entender o desenvolvimento sexual e afetivo nas novas gerações. São Paulo: Gente, 1994. 130p.

TIBA, I. Puberdade e adolescência: desenvolvimento biopsicossocial. São Paulo: Ágora, 1986. 236p.

TOMITA, N.E. Educação em saúde bucal para adolescentes: uso de métodos participativos. Revista da Faculdade de Odontologia de Bauru, v.9, n.1/2, p.63-69, jan./jun., 2001.

TONZETICH, J. Prefácio. In: ROSENBERG, M. Halitose. Rio de Janeiro: Guanabara Koogan, 2003. p.XVII - XXI.

TRAVAIN, M.E.D.C. Adolescentes de diferentes camadas sociais: medindo seu bemestar psicológico e a sua visão de Direitos Humanos. 2004. 152p. Tese (Doutorado) Faculdade de Filosofia, Ciências e Letras de Ribeirão Preto, Universidade de São Paulo, Ribeirão Preto. 2004.

TRIVIÑOS, A.N.S. Introdução à pesquisa em ciências sociais: a pesquisa qualitativa em educação. São Paulo: Atlas, 1987. 175p.

TUMIN, M.M. Estratificação social: as formas e funções da desigualdade. Tradução Dante Moreira Leite. São Paulo: Ed. Livraria Pioneira, 1970. 165p.

VIGARELLO, G. O limpo e o sujo: uma história da higiene corporal. Tradução Mônica Stahel. São Paulo: Martins Fontes, 1996. 297p.

VILELA, E. M. Desmedicalizando o conceito de saúde. 1996. 133p. Dissertação (Mestrado em Enfermagem, em Saúde Pública) - Escola de Enfermagem de Ribeirão Preto, Universidade de São Paulo. Ribeirão Preto, 1996.

WEIL, P.; TOMPAKOW, R. O corpo fala: a linguagem silenciosa dos sinais. Petrópolis: Vozes, 1999. 292p.

WEREBE, M.J.G. Sexualidade, política, educação. Campinas (SP): Editora Autores associados, 1998. 217p.

WEYNE, S.C. A Construção do paradigma de promoção de saúde: um desafio para as novas gerações. In: KRIGER, L. (org.). Promoção de saúde bucal. São Paulo: Artes Médicas, 1997. p.1-26. 
WHO/ World Health Organization/ Constitution of the World Health Organization. Basic Documents. WHO. Genebra, 1946.

Quality of Life assessment (WHOQOL): position paper from the World Health Organization. Soc Sci Med. v.41, n.10, p. 1403-109, 1995.

WIJK, R.A; SCHAB, F.R.; CAIN, W.S. Odor identification. In: SCHAB, F. R.; CROWDER, R.G. Memory for odors. Mahwah, N.J.: Laurence Erlbaum Associates, 1995. 21-37p.

WILKINS, E.M. Clinical practice of the dental hygienist. Baltimore: Williams e Wilkins, 1994. $893 \mathrm{p}$

WILLIS, C.L. et al. Negative correlation between oral malodour and numbers and activities of sulphate-reducing bacteria in the human mouth. Archives of Oral Biology, v.44, p.665670, 1999.

YAEGAKI, K.; SANADA, K. Volatile sulfur compounds in mouth air from clinically healthy subjects patients with periodontal disease. J. Peridontal Res., v.27, n. 4 Pt 1, p. 233-238, Jul, 1992.

YAEGAKI, K.; COIL, J.M. Clinical application of a questionnaire for diagnosis and treatment of halitosis. Quintessence International, v.30, n.5, p.302-306, 1999. (a)

YAEGAKI, K.; COIL, J.M. Clinical dilemmas posed by patients with psychosomatic halitosis. Quintessence International, v.30, n.5, p.328-333, 1999. (b)

ZWAARDEMAKER, H. Odoriferous materials. In: International critical tables of numerical data. Physics, chemistry and technology. National research Council. New York: MaGrawHill Book Co., 1926, 358p. 
Anexos 


\section{ANEXO A - Termo de consentimento livre e esclarecido}

\section{TERMO DE CONSENTIMENTO LIVRE E ESCLARECIDO}

A pesquisa tem como objetivo: Compreender como a halitose é vivenciada entre adolescentes e os reflexos na sua qualidade de vida. A pesquisadora esclarece que a coleta de dados será desenvolvida na escola, durante o horário das aulas, sem comprometer o rendimento do aluno. Será realizada uma entrevista individual, com duração média de 10 minutos. A entrevista será gravada em fita cassete.

Eu, , RG n.

abaixo assinado, responsável pelo adolescente a ser entrevistado, confirmo ter recebido as informações sobre a pesquisa a ser desenvolvida, e ciente dos direitos abaixo relacionados, autorizo a sua participação.

1. A garantia de receber resposta a qualquer pergunta ou esclarecimento a dúvidas acerca dos procedimentos, riscos, benefícios e outros relacionados com a pesquisa.

2. A liberdade de retirar meu consentimento a qualquer momento e deixar de participar do estudo sem que isso traga qualquer prejuízo para o entrevistado.

3. A segurança de que serão preservadas a identidade e a privacidade do entrevistado.

4. O compromisso de se valer a legislação em caso de dano.

5. A garantia de que não haverá riscos, nem desconfortos, ou gastos de qualquer natureza.

Conhecendo os direitos citados acima, cedo os direitos da entrevista gravada, para ser utilizada integralmente, ou em partes na pesquisa desenvolvida pela cirurgiã-dentista

MARINA SÁ ELIAS PADILHA, inscrita no CROSP - Conselho Regional de Odontologia do Estado de São Paulo, sob o ${ }^{\circ}$ 56.938, que se compromete a seguir todas as exigências que constam da resolução n. 196 de 10 de outubro de 1996, que regulamenta o desenvolvimento de pesquisas envolvendo seres humanos.

Desde já agradecemos a importante colaboração.

Ribeirão Preto, de de 2004.

Assinatura: 


\section{ANEXO B - Protocolo de aprovação do Comitê de Ética}
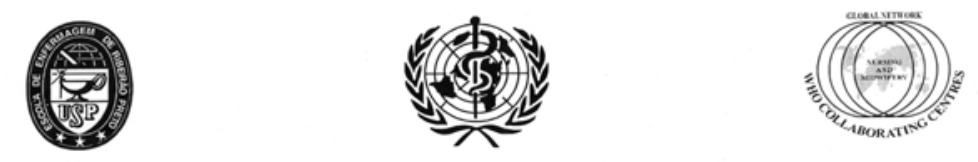

ESCOLA DE ENFERMAGEM DE RIBEIRÃO PRETO - UNIVERSIDADE DE SÃO PAULO CENTRO COLABORADOR DA ORGANIZAÇ̃̃O MUNDIAL DA SAÚDE PARA O DESENVOLVIMENTO DA PESQUISA EM ENFERMAGEM

Avenida Bandeirantes, 3900 - Campus Universitário - Ribeirăo Preto - CEP 14040-902 - São Paulo - Brasil FAX: $55-16-633-3271 / 55-16-630-2561$ - TEL LFONES: 55 - 16-633-0379/602-3382

COMITÊ DE ÉICA EM PESQUISA DA EERP/USP

Of.CEP-EERP/USP - 0124/2005

Ribeirão Preto, 6 de outubro de 2005

Prezada Senhora

Comunicamos que o projeto de pesquisa, abaixo especificado, foi analisado e considerado APROVADO pelo Comitê de Ética em Pesquisa da Escola de Enfermagem de Ribeirão Preto da Universidade de São Paulo, em sua $79^{\circ}$ Reunião Ordinária, realizada em 28 de setembro de 2005.

Protocolo: $\quad n^{\circ} 0529 / 2005$

Projeto: Halitose em Adolescentes

Pesquisadores: Maria das Graças Bomfim de Carvalho (Orientadora) Marina Sá Elias Padilha

Em atendimento à Resolução 196/96, deverá ser encaminhado ao CEP - relatório final da pesquisa e a publicação de seus resultados, para acompanhamento, bem como comunicada qualquer intercorrência ou a sua interrupção.

Atenciosamente,

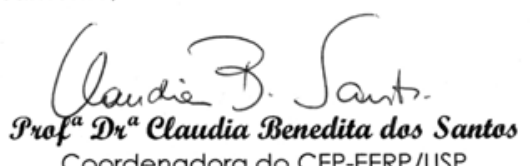

Coordenadora do CEP-EERP/USP

$\| m^{a} . S r^{\circ}$.

Profa. Dra. Maria das Graças Bomfim de Carvalho (Orientadora)

Departamento de Enfermagem Materno-Infantil e Saúde Pública Escola de Enfermagem de Ribeirão Preto-USP 
ANEXO C - Declaração de autorização para desenvolvimento da pesquisa na escola - Vita et Pax

\section{E C L A R A Ç Ã O}

Declaro para os devidos fins que a cirurgiã-dentista MARINA SÁ ELIAS PADILHA, inscrita no CRO(SP) - Conselho Regional de Odontologia do Estado de São Paulo,sob o $\mathrm{n}^{\circ}$ 56.938, aluna do programa de Pós-Graduação - Área Enfermagem em Saúde Pública - Nível Doutorado da Escola de Enfermagem da Universidade de São Paulo-USP, está autorizada a realizar a coleta de dados necessária para a elaboração de sua tese de Doutorado na escola: VITA ET PAX, localizada no endereço: Av. Abade Constantino n. 174, na cidade de Ribeirão Preto, SP.

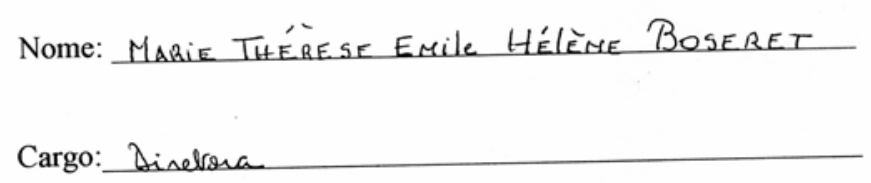

Ribeirão Preto, 14 de maneo de 2005

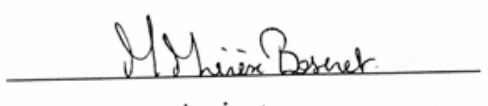

Assinatura.

Marie Thérèse E. Helene Boseret

Drrora-MEC Rg. 13531 - RNE WOSBBA9-Y 


\title{
ANEXO D - Declaração de autorização para desenvolvimento da pesquisa na escola EE. Prof. Sebastião Fernandes Palma
}

\author{
D E C L A R A Ç Ã O
}

Declaro para os devidos fins que a cirurgiã-dentista MARINA SÁ ELIAS PADILHA, inscrita no CRO(SP) - Conselho Regional de Odontologia do Estado de São Paulo,sob o $\mathrm{n}^{\circ}$ 56.938, aluna do programa de Pós-Graduação - Área Enfermagem em Saúde Pública - Nível Doutorado da Escola de Enfermagem da Universidade de São Paulo-USP, está autorizada a realizar a coleta de dados necessária para a elaboração de sua tese de Doutorado na escola: EE PROF SEBASTIÃo FERNANDES PALMA, localizada no endereço: R. Casemiro de Abreu n. 595 Bairro: Vila Seixas, na cidade de Ribeirão Preto, SP.

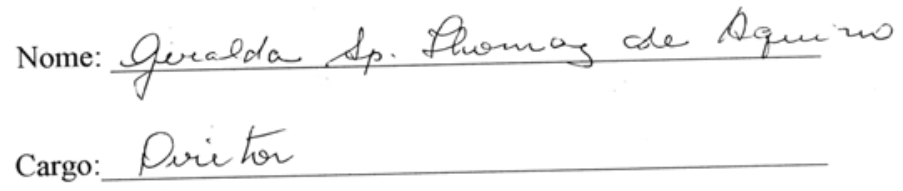

Ribeirão Preto, 15 de mar co, de 2005

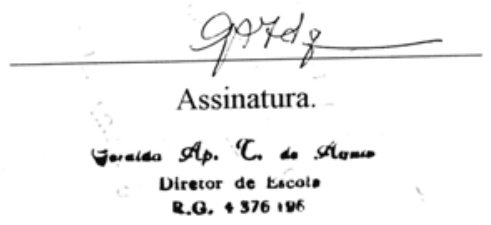


ANEXO E - Declaração de autorização para desenvolvimento da pesquisa na escola EMEF. Vereador José Delibo

\author{
D E C L A R A Ç Ã O
}

Declaro para os devidos fins que a cirurgiã-dentista MARINA SÁ ELIAS PADILHA, inscrita no CRO(SP) - Conselho Regional de Odontologia do Estado de São Paulo,sob o $\mathrm{n}^{\circ}$ 56.938, aluna do programa de Pós-Graduação - Área Enfermagem em Saúde Pública - Nível Doutorado da Escola de Enfermagem da Universidade de São Paulo-USP, está autorizada a realizar a coleta de dados necessária para a elaboração de sua tese de Doutorado na escola: EMEF VEREADOR JOSÉ DELIBO, localizada no enderę̧o: R. Serafim Teixeira da Cunha n. 555 Bairro: Jardim Castelo Branco na cidade de Ribeirão Preto, SP.

Nome: ZILDA PERKIRA DA SIWA
Cargo: DIRETORA

Ribeirão Preto, 14 de manw de 2005

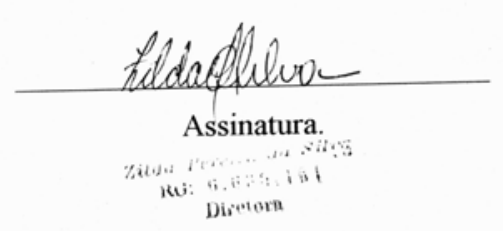


ANEXO F - Declaração de autorização para desenvolvimento da pesquisa na escola Prof. José Rodini Luiz

D E C L A R A C Ã O

Declaro para os devidos fins que a cirurgiã-dentista MARINA SÁ ELIAS PADILHA, inscrita no CRO(SP) - Conselho Regional de Odontologia do Estado de São Paulo,sob o $\mathrm{n}^{\circ}$ 56.938, aluna do programa de Pós-Graduação - Área Enfermagem em Saúde Pública - Nivel Doutorado da Escola de Enfermagem da Universidade de São Paulo-USP, está autorizada a realizar a coleta de dados necessária para a elaboração de sua tese de Doutorado na escola: EMEF PROF. JOSÉ RODINI LUIZ, localizada no endereço: R. José Ignacchitti n. 700 Bairro: Jardim Zara, na cidade de Ribeirão Preto, SP.

Nome: Pilton CézAr ferenerRa dat SILVA

Cargo: DIRETOR DE GECOLA

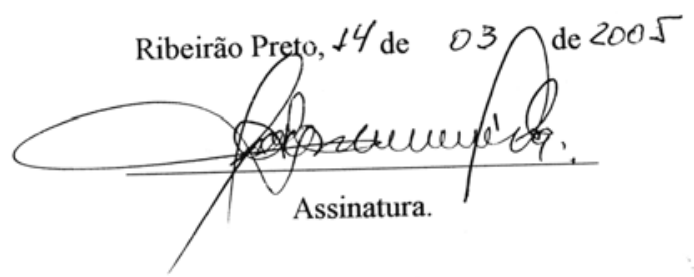




\section{ANEXO G - Decreto no 333 de 26 de dezembro de 1983 da Prefeitura Municipal de Ribeirão Preto}

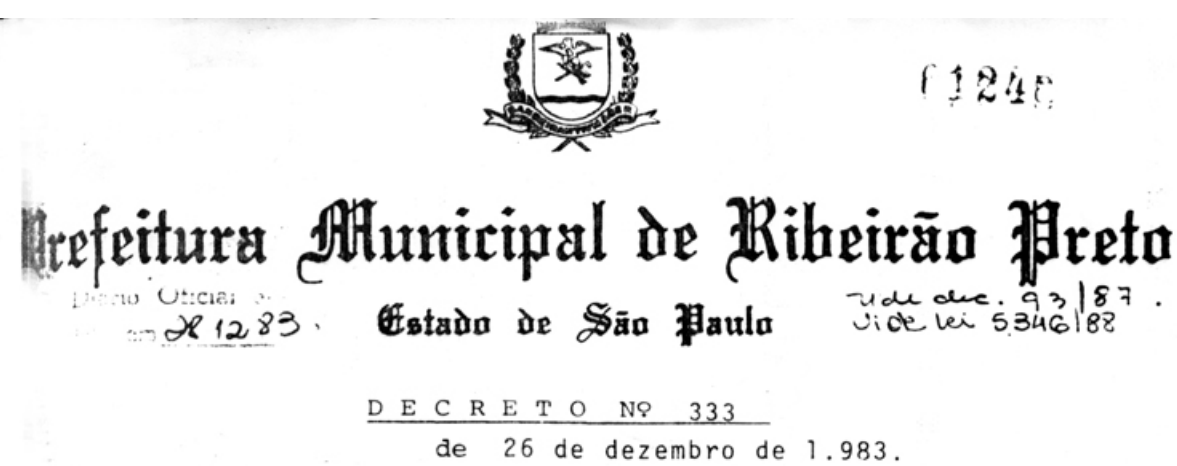

DEFINE E DELIMITA SETORES E SUBSETORES NO DISTRI TO SEDE DO MUNICIPIO DE RIBEIRÃO PRETO.

DR. JOÃO GILBERTO SAMPAIO, Prefeito Municipal de Ribeirão Preto, usando das atribuições que lhe são conferidas Dor lei,

DEC RET A:

\section{CAPITULO I}

DOS OBJETIVOS

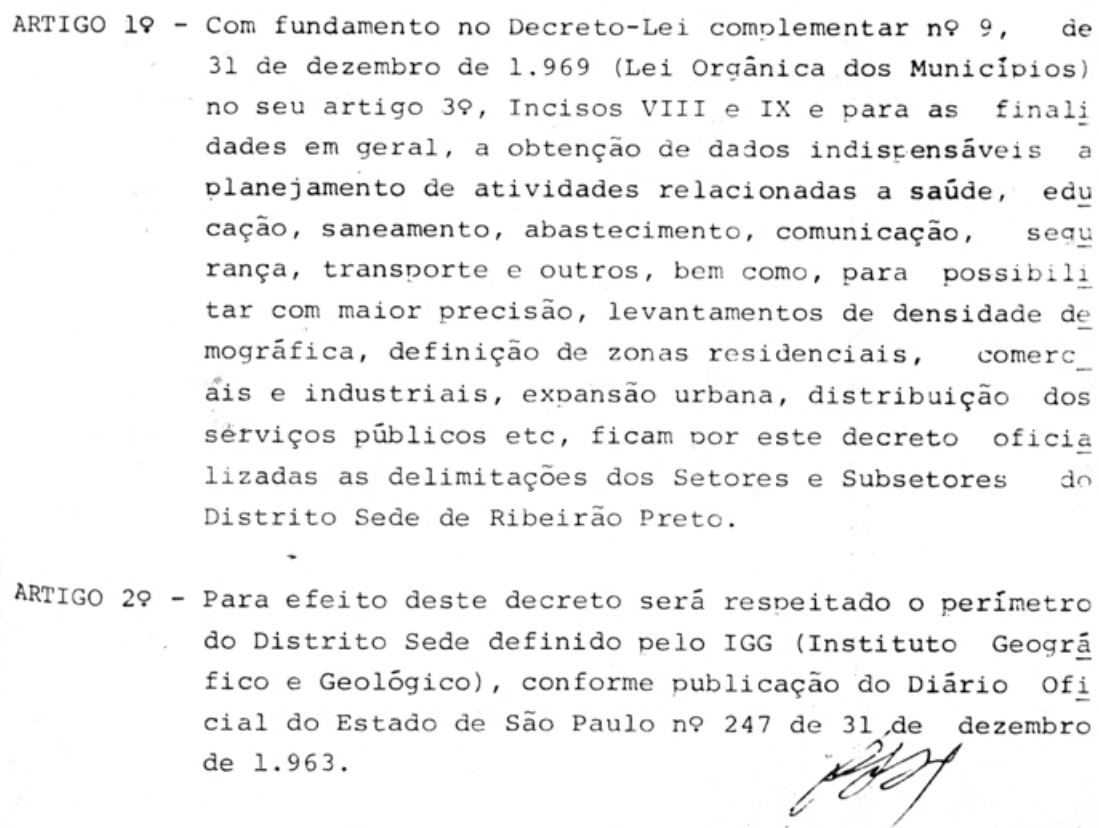




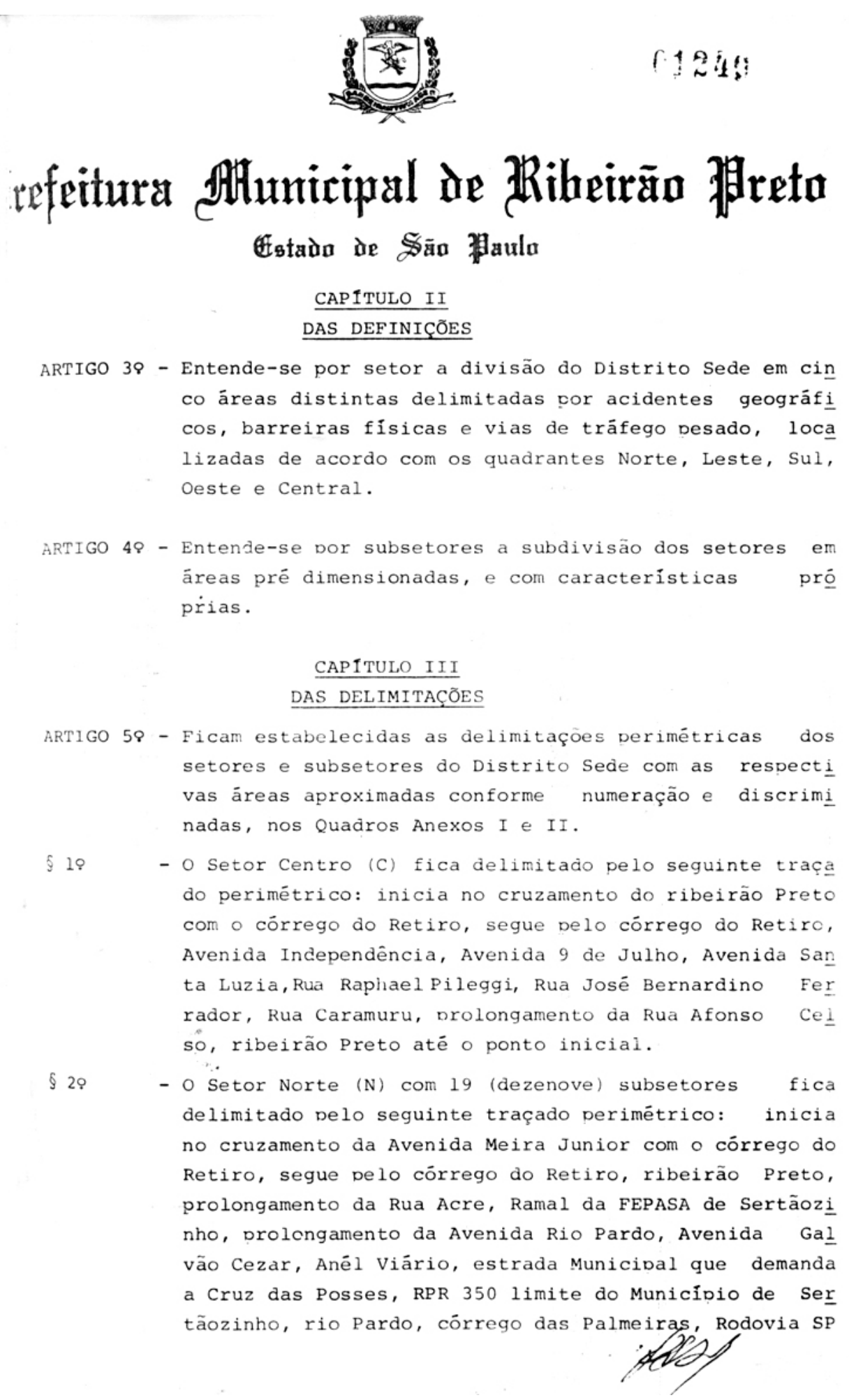




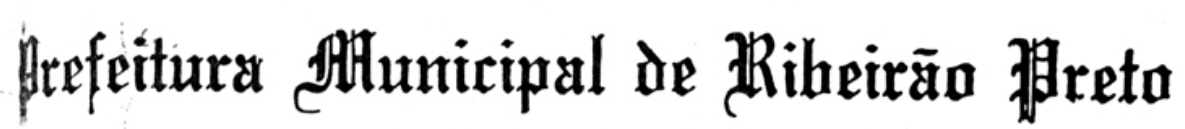

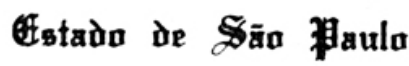

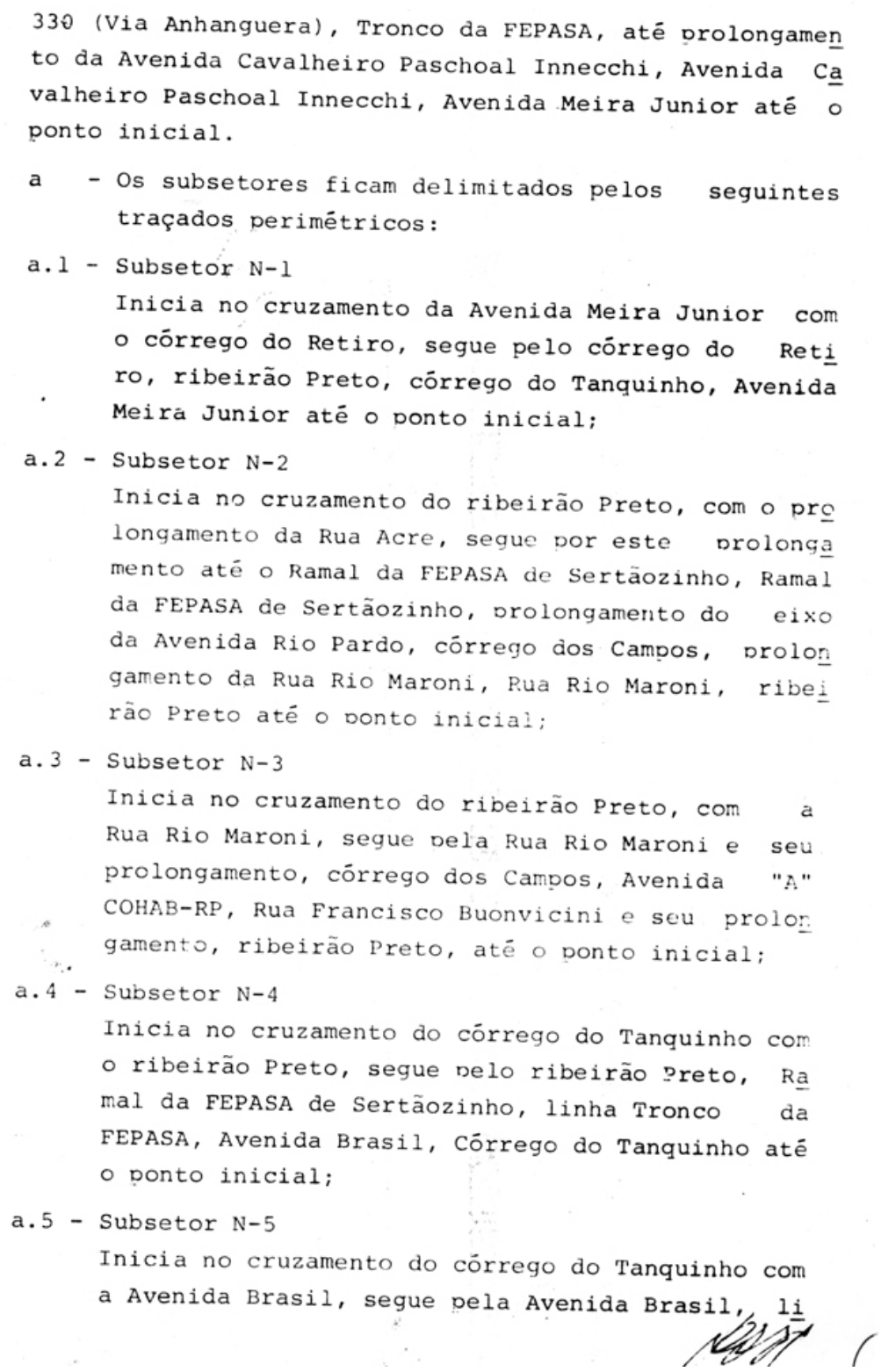




\section{(5)

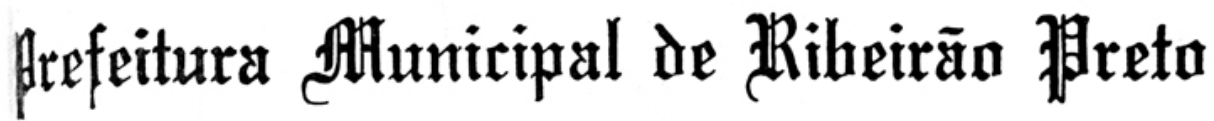

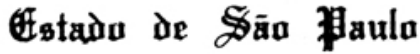

nha Tronco da FEPASA até o prolongamento da Aveni da Cavalheiro Paschoal Innecchi, Avenida Cavalhei ro Paschoa Innecchi, cōrrego do Tanquinho até o ponto inicial;

a.6 - Subsetor $\mathrm{N}-6$

Inicia no cruzamento do córrego dos campos com o prolongamento do eixo da Avenida Rio Pardo, segue pelo prolongamento do eixo da Avenida Rio Pardo, Avenida Luiz Galvão Cezar, Anēl viário, ribeirão Preto, córrego dos Cambos até o ponto inicial;

.7 - Subsetor $\mathrm{N}-7$

Inicia no cruzamento do ribeirão Preto, com o prolongamento da Rua Francisco Buonvicini, segue pelo prolongamento da Rua Francisco Buonvicini, Avenida "A" COHAB-RP, córrego dos Campos, ribei rão Preto, até o ponto inicial;

a. 8 - Subsetor $\mathrm{N}-8$

Inicia no cruzamento do Ramal da FEPASA de Sertão zinho com o ribeirão Preto, segue delo ribeiràc Preto, Anél Viário, prolongamento do Ramal da FEPASA, terminal de Petróleo, Ramal da FEPASA do terminal de Petróleo, Ramal da FEPASA de Sertãozi nho até o ponto inicial;

a. 9 - Subsetor $\mathrm{N}-9$

Inicia na bifurcação da linha Tronco da FEPASA. com o Ramal do terminal de Petróleo, segue pelo Ramal do terminal de Petróleo e seu prolongamento Anél Viārio, Rodovia SP 330 (Via Anhanguera) li nha Tronco da FEPASA até o ponto inicial;

a.10 - Subsetor $\mathrm{N}-10$ Inicia no cruzamneto da linha Tronco da FEPASA com a Avenida Thomaz Alberto Whately, segue pela Avenida Thomaz Alberto Whately, Avenida Milton Ta pajos Roselino, linha Tronco da FEPASA até 0 pon to inicial;

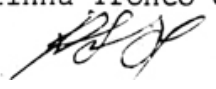




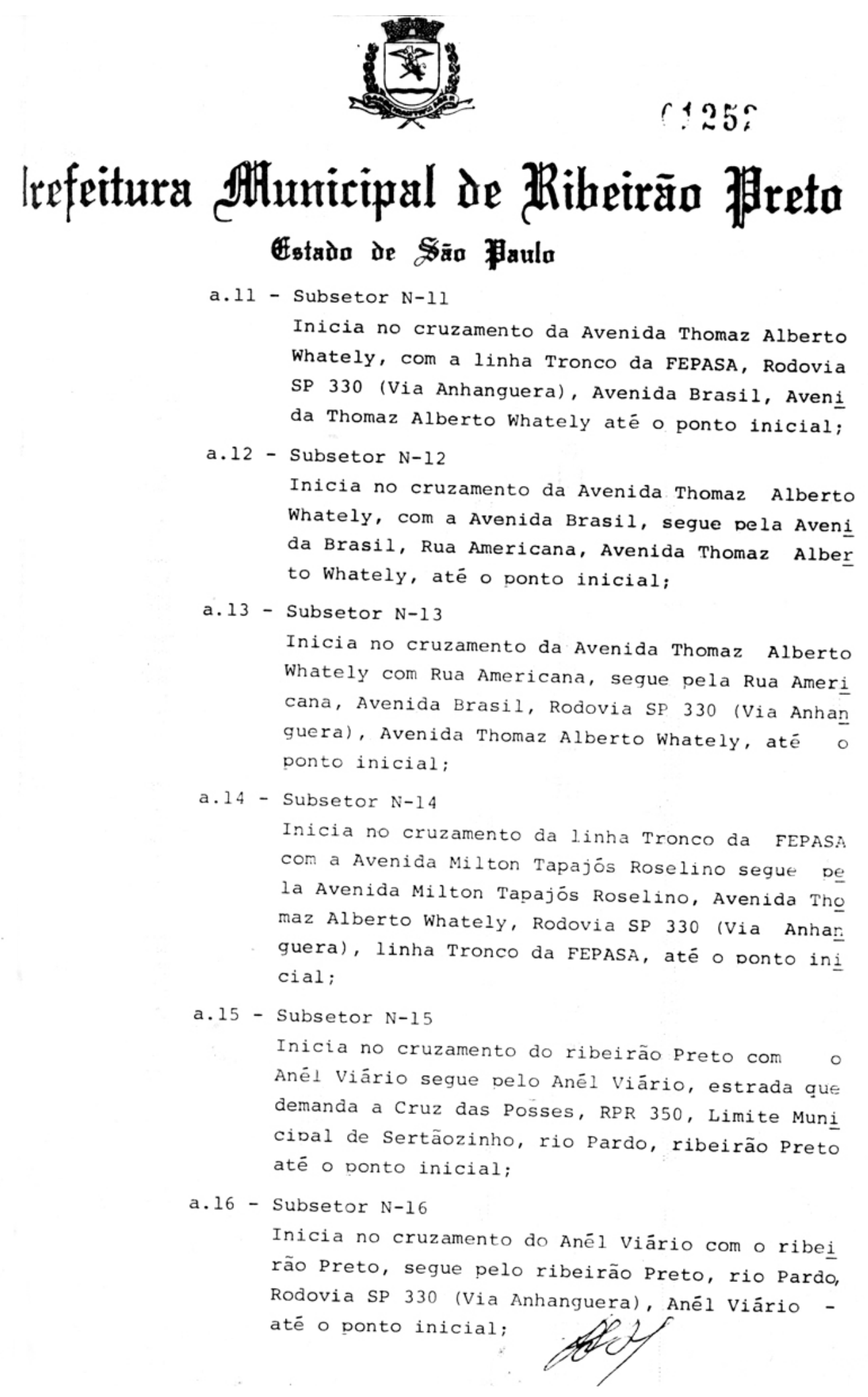




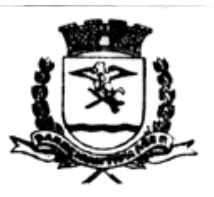

\section{rescis}

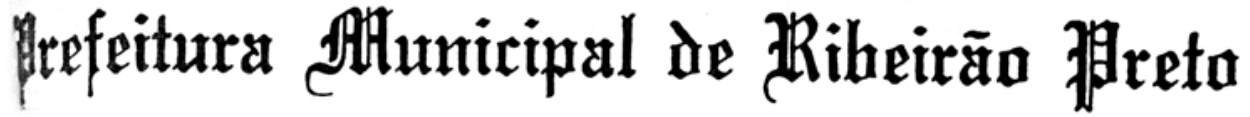

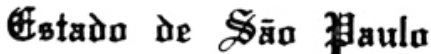

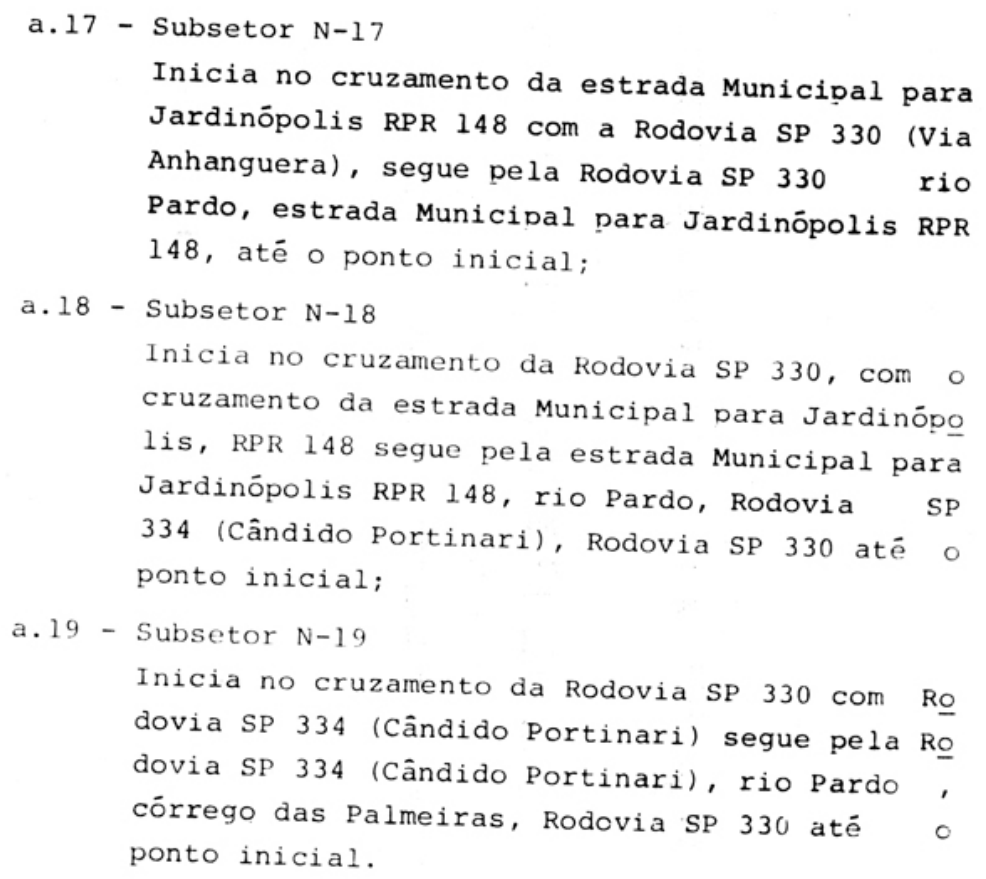

- O Setor Leste (L) com 13 Subsetores fica delimitadopelo seguinte traçado perimétrico: inícia no cruzamen to da Avenida 9 de Julho com Avenida Independência sê gue pela Avenida Independência, Avenida Meira Junior, Avenida Cavalheiro Paschoal Innecchi e seu prolonga mento, linha Tronco da FEPASA, Rodovia SP 330 (Via A nhánguera), córrego das Palmeiras, rio Pardo, divisa do município com Serrana, divisa com Município de Cra vinhos SP 330 , estrada Municipal, que liga a SP 330 com SP 255-RPR 352, cōrrego do Retiro, Avenida 9 de Julho atē o ponto inicial.

a - Os subsetores ficam delimitados pelos seguintes traçados perimétricos:

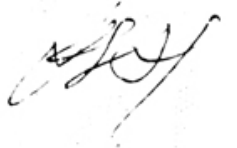




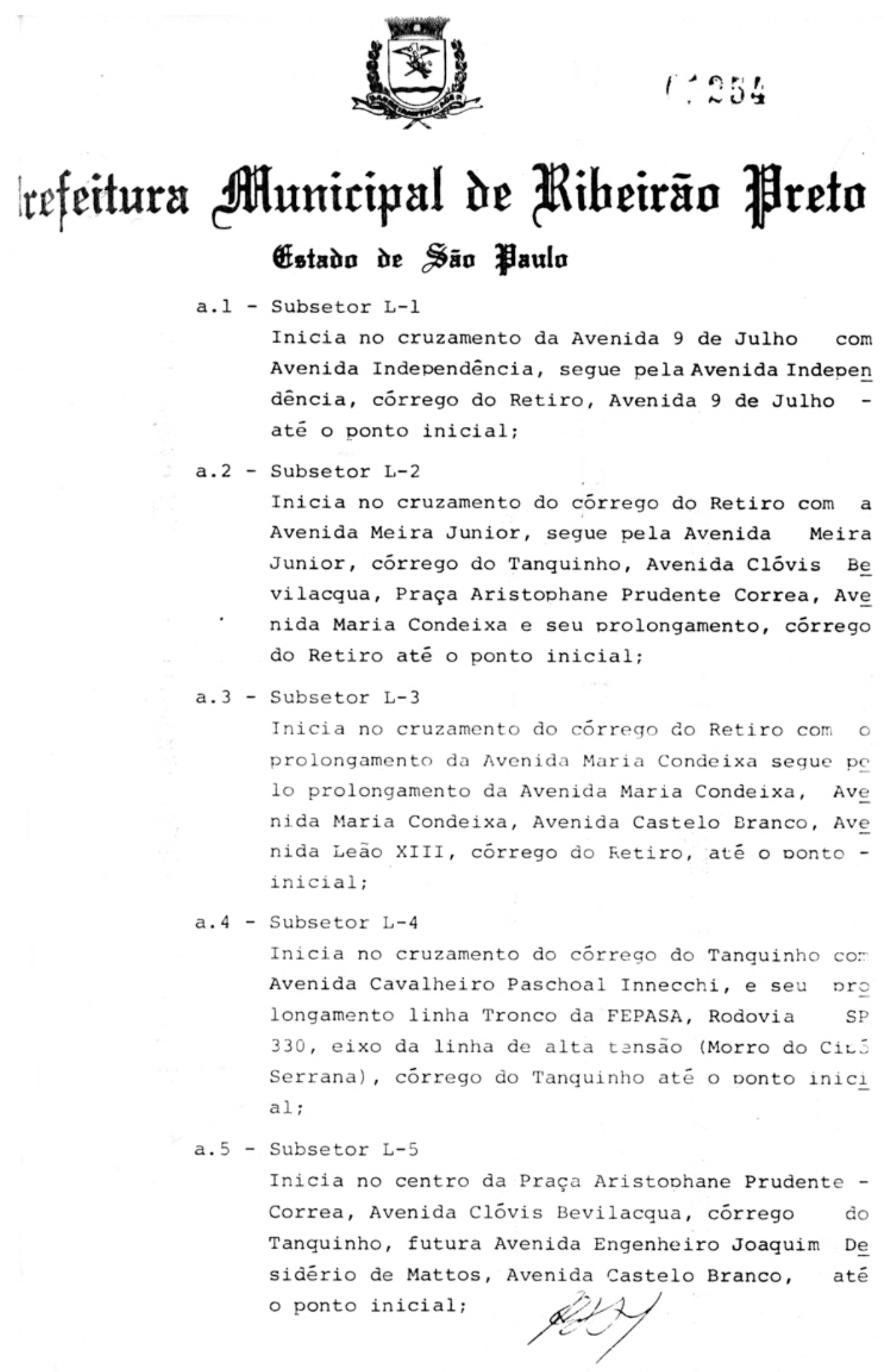




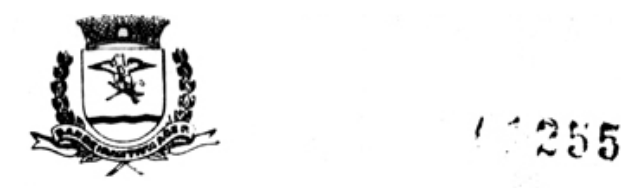

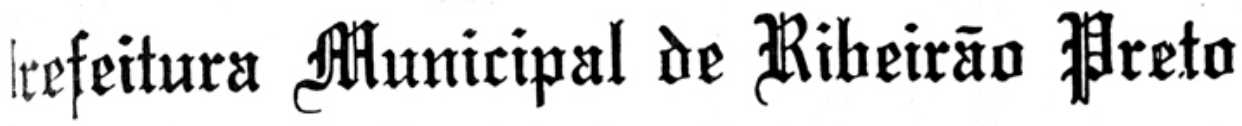

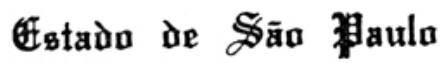

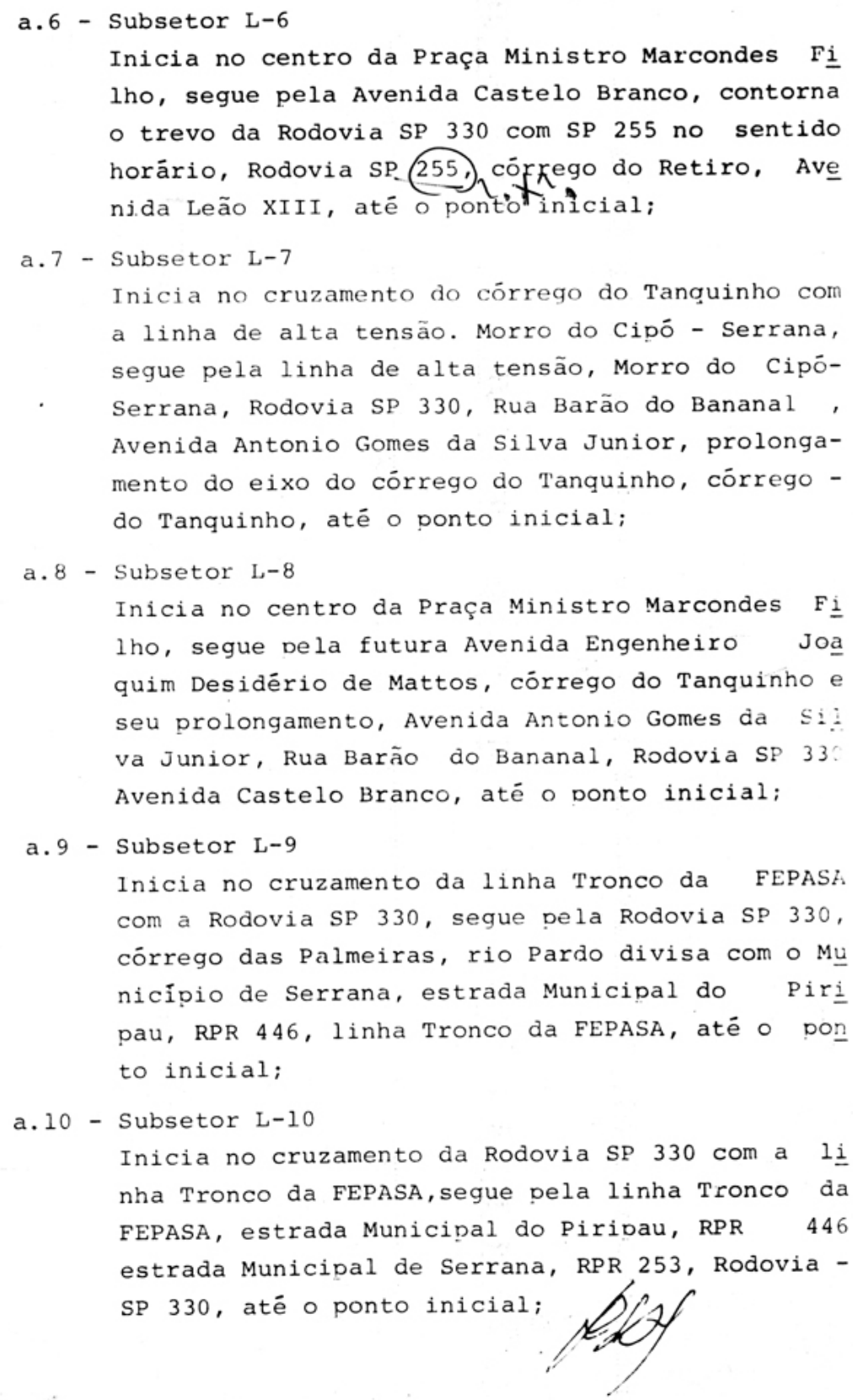




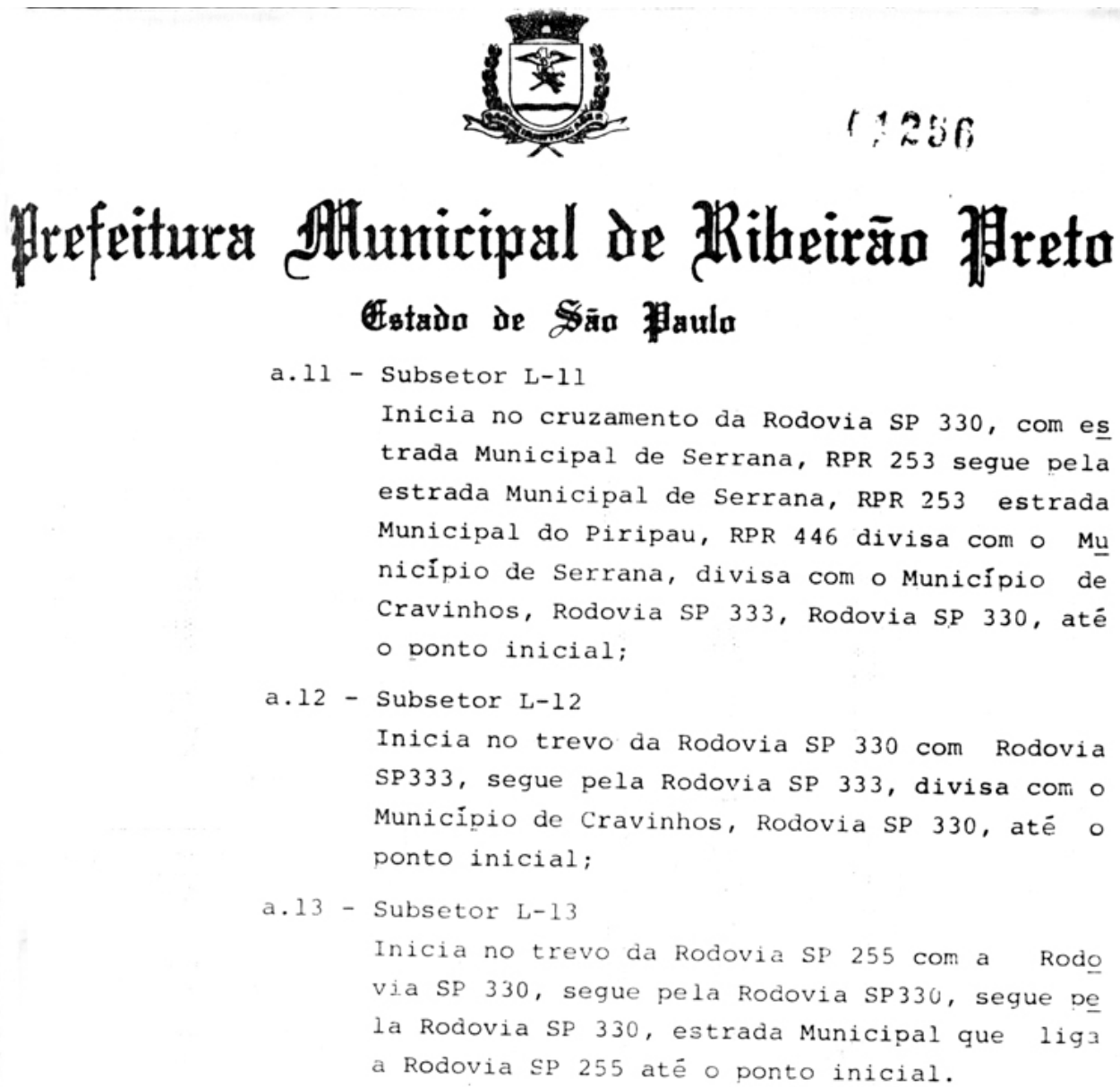

- O Setor Sul (S), com 10 subsetores, fica delimitadorpelo seguinte traçado perimétrico: inicia no cruzamen to da Avenida Santa Luzia com a Avenida 9 de Julnc, segue pela Avenida 9 de Julho, cörrego do Retiro, es trada Municipal que liga a Rodovia SP $255 \mathrm{com}$ a Rodo via SP 330, RPR 352, Rodovia SP 330, divisa com o Mu hicípio de Cravinhos, divisa interdistrital do Distri to de Bo:fim Paulista com o Distrito Sede, Rodovia SL 328, Anél Viārio, divisa interdistrital do Distrito de Bonfim Paulista com o distrito Sede, divisa interdistritral do Distrito de Guaranará com o Distrito Se de, aivisa com o Município de Dumont, linha de alta tensão, Laranjeiras - Iguapé - Ribeirão Preto, RPR 349, estrada Municipal de Guatanará, ribeirão Preto, prolongamento da Rua Conde Afonso Celso, Avenida Cara murū, Rua José Bernardino Ferrador,R. Raphael Pileggi Avenida Santa Luzia até o ponto inicial.

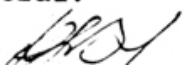




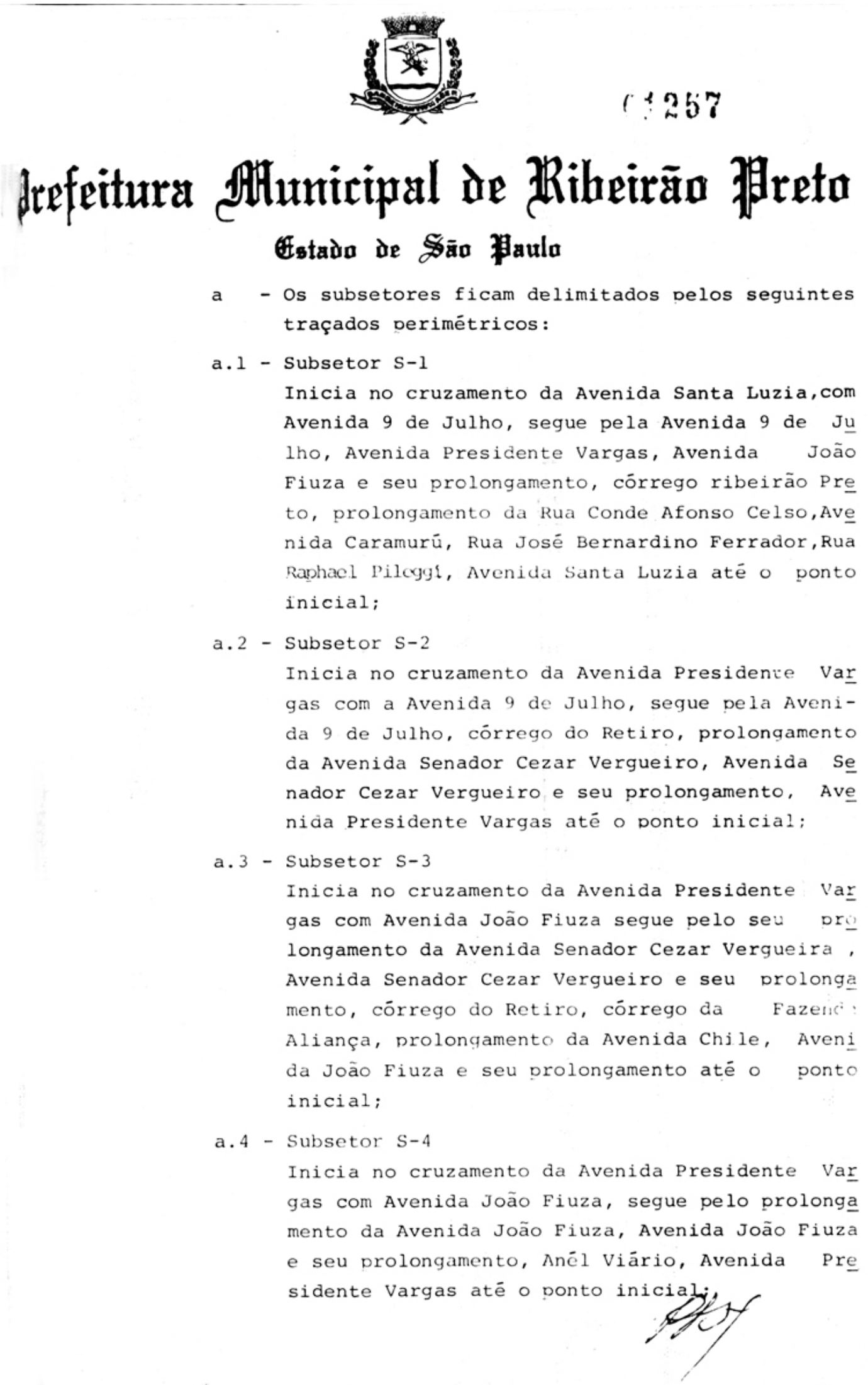




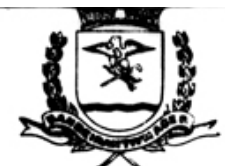

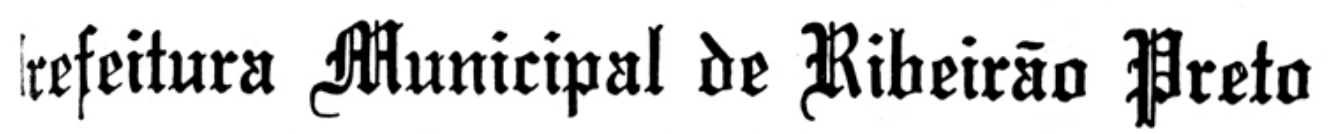

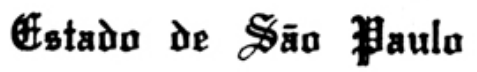

a.5 - Subsetor S-5

Inicia no cruzamento da Avenida João Fiuza com Avenida Presidente Vargas, segue pela Avenida Presidente Vargas, Anēl Viārio, ribeirão Pre to, prolongamento da Avenida João Fiuza, Aven $\underline{i}$ da João Fiuza, até o ponto inicial;

a. 6 - Subsetor s-6

Inicia no cruzamento do córrego da Fazenda Ali ança com o cōrrego do Retiro, segue pelo cōr rego do Retiro, Rodovia SP 255, Anēl Viārio, córrego da Fazenda Aliança até o ponto inicí al;

a.7 - Subsetor $\mathrm{S}-7$

Inicia no cruzamento da Avenida João Fiuza, com Avenida Chile, segue pela Avenida Chile e seu prolongamento, córrego da Fazenda Aliança,Anél Viārio, prolongamento da Avenida João Fiuza , até o ponto inicial;

a. 8 - Subsetor $S-8$

Inicia no cruzamento da Rodovia SP $255 \mathrm{com}$. córrego do Retiro, segue pelo cörrego do Reti ro, estrada Municipal que liga a Rodovia SP 255 com a Rodovia SP 330, RPR 352 Rodovia SP 330, divisa com o Município de Cravinhos, divi sa interdistrital de Bonfim Paulista com o Dis trito Sede, Rodovia SP 255 até o ponto inici al;

a.9 - Subsetor S-9

Inicia no cruzamento da Avenida Presidente Var gas com o Anēl Viărio, segue pelo Anēl Viārio, Rodcvia SP 255, divisa interdistrital de Bon fim Paulista com o Distrito Sede, Rodovia sP 328 até o ponto inicial;

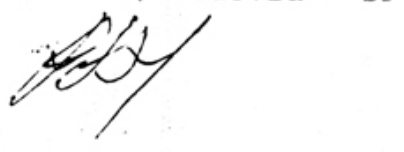




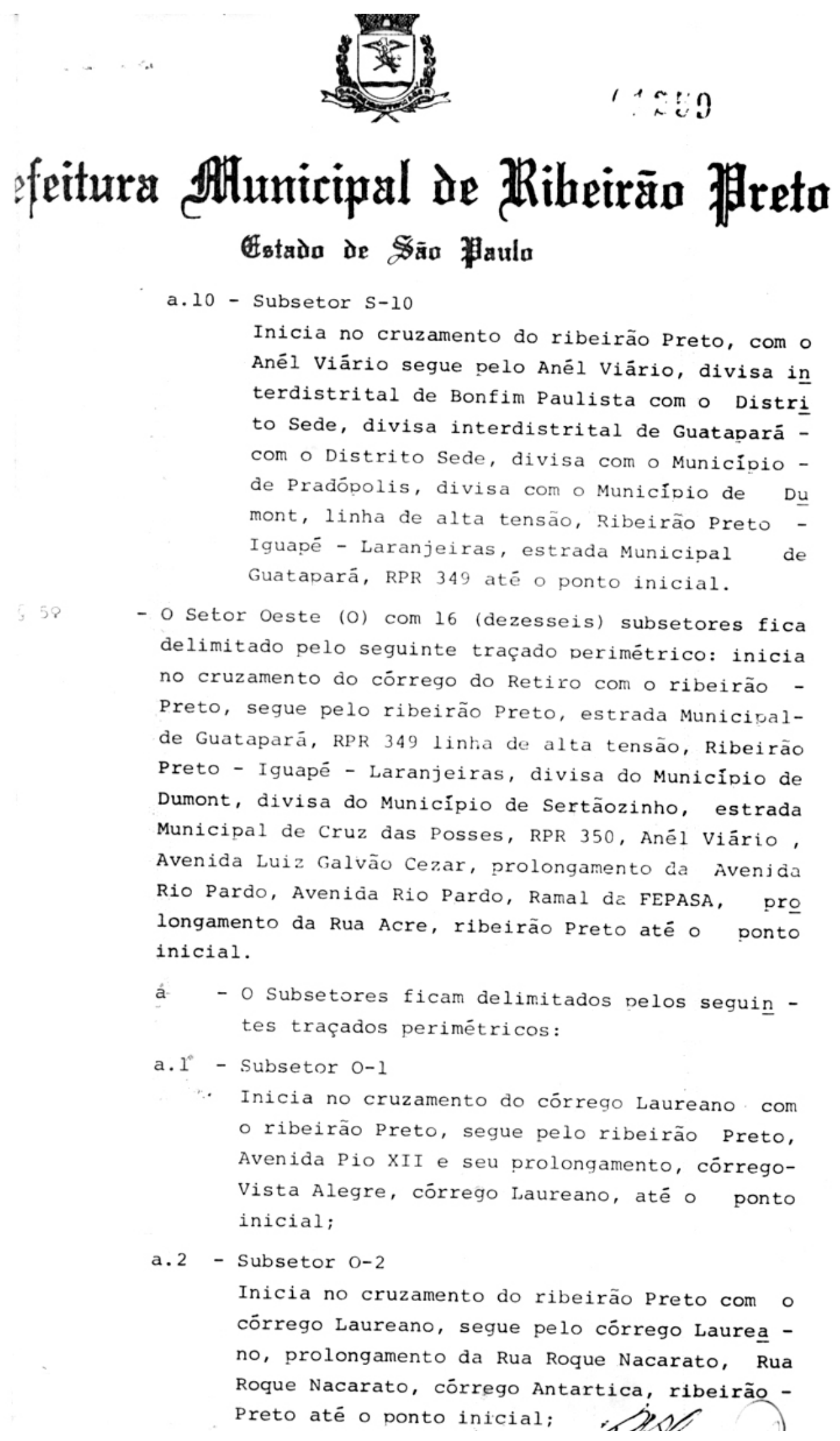




\section{$r+260$}

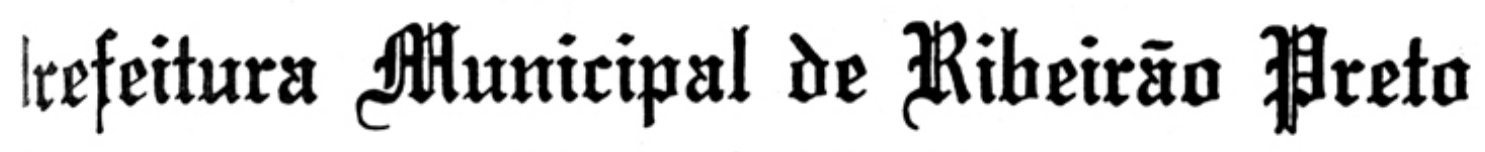

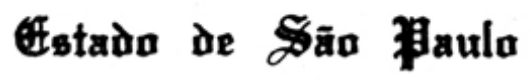

a. 3 - Subsetor $\mathrm{C}-3$

Inicia no cruzamento da Avenida Pio XII com o rí beirão Preto, segue pelo ribeirão Preto, Avenida Luzitano, Avenida Monteiro Lobato, Avenida Pio XII até o ponto inicial;

a. 4 - Subsetor $0-4$

Inicia no cruzamento da Avenida Pio XII com Ave nida Monteiro Lobato, segue pela Avenida Monteiro Lobato, Avenida Cásper Líbero, Avenida Profes sor Pedreira de Freitas, córrego Vista Alegre, continuação da Avenida Pio XII, Avenida Pio XII, até o ponto inicial;

a. 5 - Subsetor 0-5

Inicia no cruzamento do prolongamento da Rua Ro que Nacarato com o cōrrego Laureano, segue pelo córrego Laureano, ligação da Avenida Bandeiran tes com a Avenida do Café, no Campus, Avenida Luigi Rosíello, Avenida Paranapanema, cōrrego An tártica, Rua Roque Nacaratc e seu prolongamento, até o ponto inicial;

a.6 - Subsetor $0-6$

Inicia no cruzamento do córrego Antārtica com Avenida Paranapanema segue dela Avenida Paranapa nema, Ramal da FEPASA de Sertãozinho, prolongą mento da Rua Acre, ribeirão Preto, cōrrego Antár tica até o ponto inicial;

a. 7 - Subsetor $0-7$

Inicia no cruzamento da Avenida Luzitano com o ribeirão Preto, segue pelo ribeirão Preto, Anēl Viārio, divisa do Horto Municipal, Avenida Cás per Libero, Avenida Luzitano até o ponto inicí al;

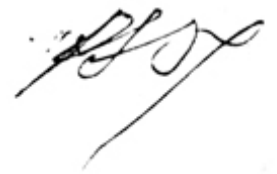




\section{$r+261$}

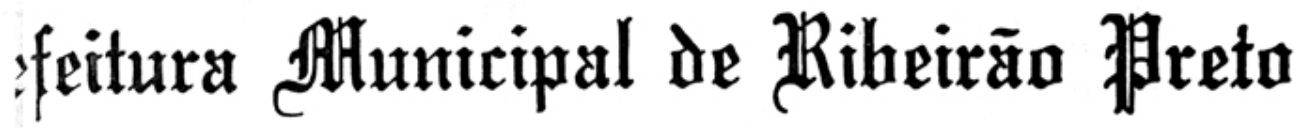

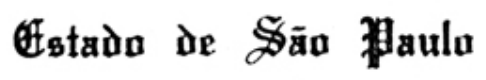

a. 8 - Subsetor 0-8

Inicia no cruzamento do córrego Vista Alegre com - prolongamento da Avenida Professor Pedreira de Freitas, segue pelo prolongamento da Avenida Pro fessor Pedreira de Freitas Avenida Pedreira de Freitas, Avenida Cásper Libero, divisa do Horto Municipal, Anél Viārio, cōrrego Vista Alegre até o ponto inicial;

a. 9 - Subsetor $0-9$

Inicia no cruzamento do córrego Laureano, com o cōrrego Vista Alegre, segue pelo córrego Vista $\underline{A}$ legre, Anél Viário, córrego Monte Alegre, cō rego Laureano até o ponto inicial;

a. 10 - Subsetor $0-10$

Inicia no cruzamento da Avenida Bandeirantes com - cōrrego Monte Alegre, segue pelo córrego Monte Alegre, Anél Viārio, Avenida Bandeirantes, até o ponto inicial;

a.11 - Subsetor 0-11

Inicia no cruzamento do Ramal da FEPASA de Ser . tãozinho com Avenida Paranapanema, segue pela $\underline{A}$ venida Paranabanema, Avenida Luigi Rosíello, li gação da Avenida do Café com a Avenida Bandeiran tes, no Campus, córrego Laureano, córrego Monte Alegre, Avenida Bandeirāntes, Anél Viārio, Ramal da FEPASA de Sertãozinho, até o ponto inicial;

a. 12 - Subsetor 0-12

Inicia no cruzamento da Avenida Paranapanema com - Ramal da FEPASA de Sertãozinho, segue pelo Rạ mal da FEPASA, Anél Viārio, Avenida Luiz Galvão Cezar, prolongamento da Avenida Rio Pardo, Ramal da FEPASA de Sertãozinho atē o ponto inicial;

a.13 - Subsetor 0-13

Inicia no cruzamento do Anél Viário com a Esträ da Municipal que demanda a Guataparā, RPR 349, seque pela Estrada Municinal de Guatanará. RPR 


\title{
芜 r.262 \\ |erfeitura Altumicipal da Rhiheirãa 脏reta

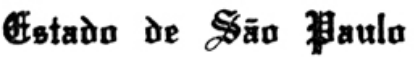

\author{
349, linha de alta tensão, ribeirão Preto - Igua \\ pé - Laranjeiras, divisa Municipal de Dumont, RPR \\ 070, estrada Municipal que demanda a Dumont RPR \\ 070, córrego do Monte Alegre, Anēl Viārio, até \\ o ponto inicial; \\ a.14 - Subsetor 0-14 \\ Inicia no cruzamento do Anēl Viário com o cörre- \\ go Monte Alegre, segue pelo cōrrego Monte Alegre \\ Estrada Municidal que demanda Dumont, RPR 070, \\ divisa Municipal de Sertãozinho, Rodovia SP 333 , \\ Anēl Viārio, até o ponto inicial; \\ a.15 - Subsetor 0-15 \\ Inicia no cruzamento do Ramal da FEPASA de Sez \\ tãozinho com o Anél Viário, segue pelo Anël Viā \\ rio, Rodovia SP 333 , divisa Municidal de Sertão- \\ zinho, Ramal da FEPASA de Sertãozinho, até o pon \\ to inicial; \\ a.16 - Subsetor 0-16 \\ Inicia no cruzamento da Estrada Nunicipal que \\ demanda a Cruz das Posses, RPR 350 com Anēl Viạ \\ rio, segue pelo Anēl Viārio, Ramal da FEPASA de \\ Sertãozinho, divisa Municipal de Sertãozinho, Es \\ trada Municipal, Cruz das Posses, RPR 350, até o \\ ponto inicial. \\ $\S 6 ?^{\circ} \quad-$ A áiea aproximada em Km2 por setor e subsetor \\ consta no Anexo no I. \\ AR'TIGO 69 - Este decreto entrarā em vigor na data de sua pu \\ blicação, revogadas as disposições ex/contrāyio.

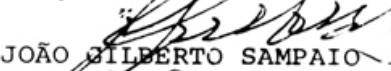 \\ Prefle to Municipal \\ ANTONIO FERNANO-ALVES FEITOSA \\ Secretarto de fovefno \\ JOSE ARNALDO ANDREOTTI \\ Secretárió dos Nelácios Jurídicos
}




\section{3}

\section{efpitura 舫}

\section{Gratado de $\mathscr{S}$ ãa faula ANEXO NO I}

SETORES E SUBSETORES COM AS RESPECTIVAS AREAS

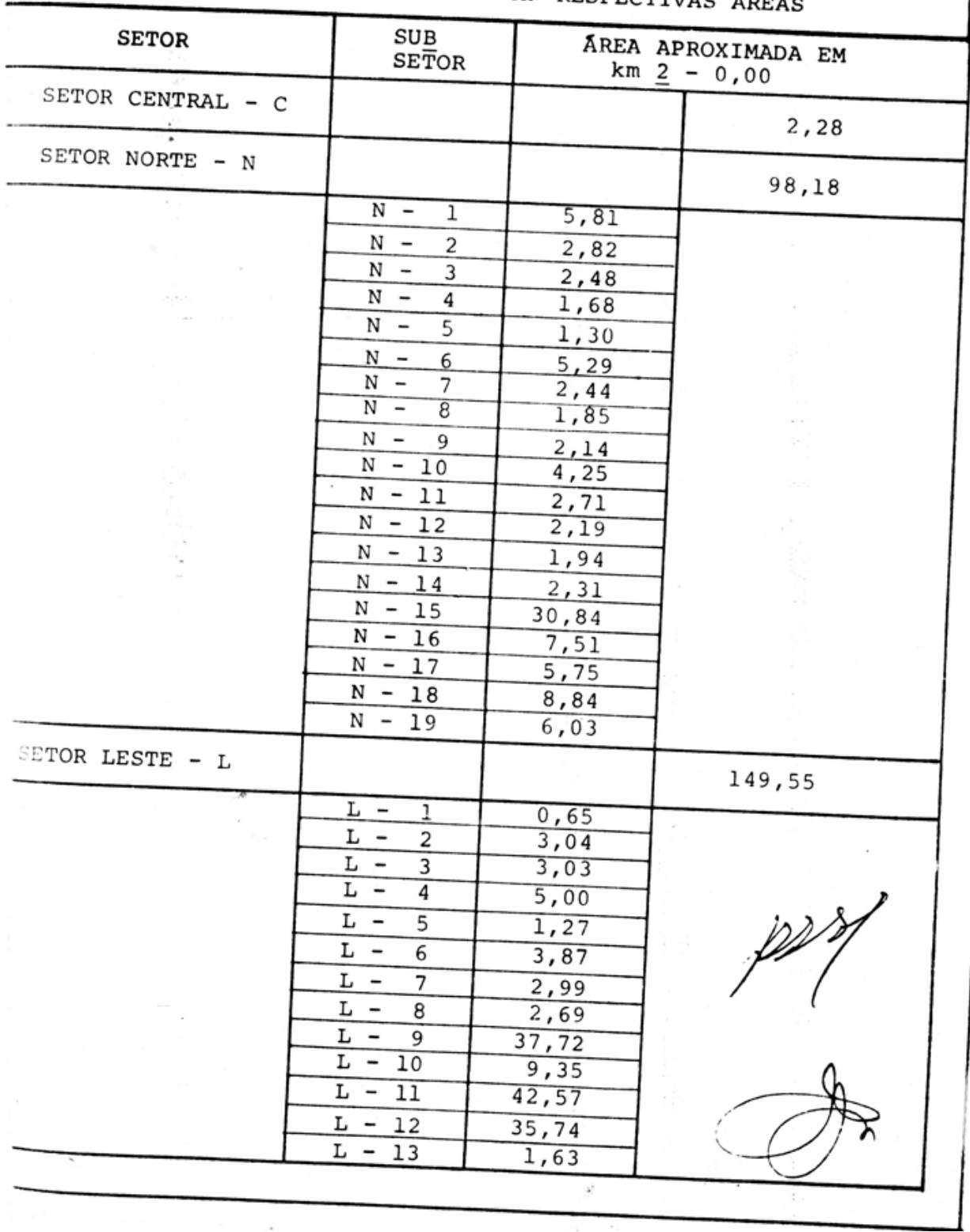




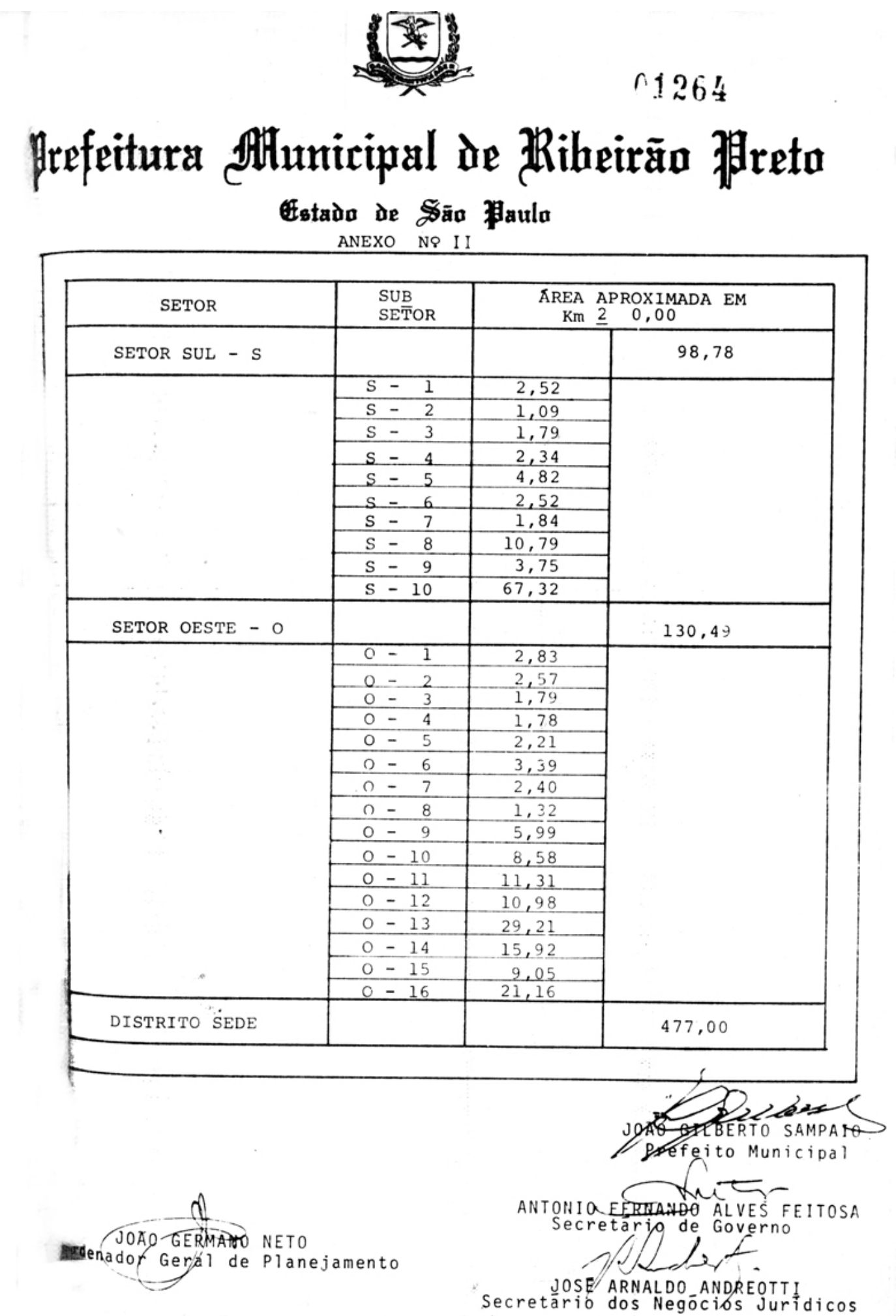


ANEXO H - Mapa com os subsetores do Município de Ribeirão Preto

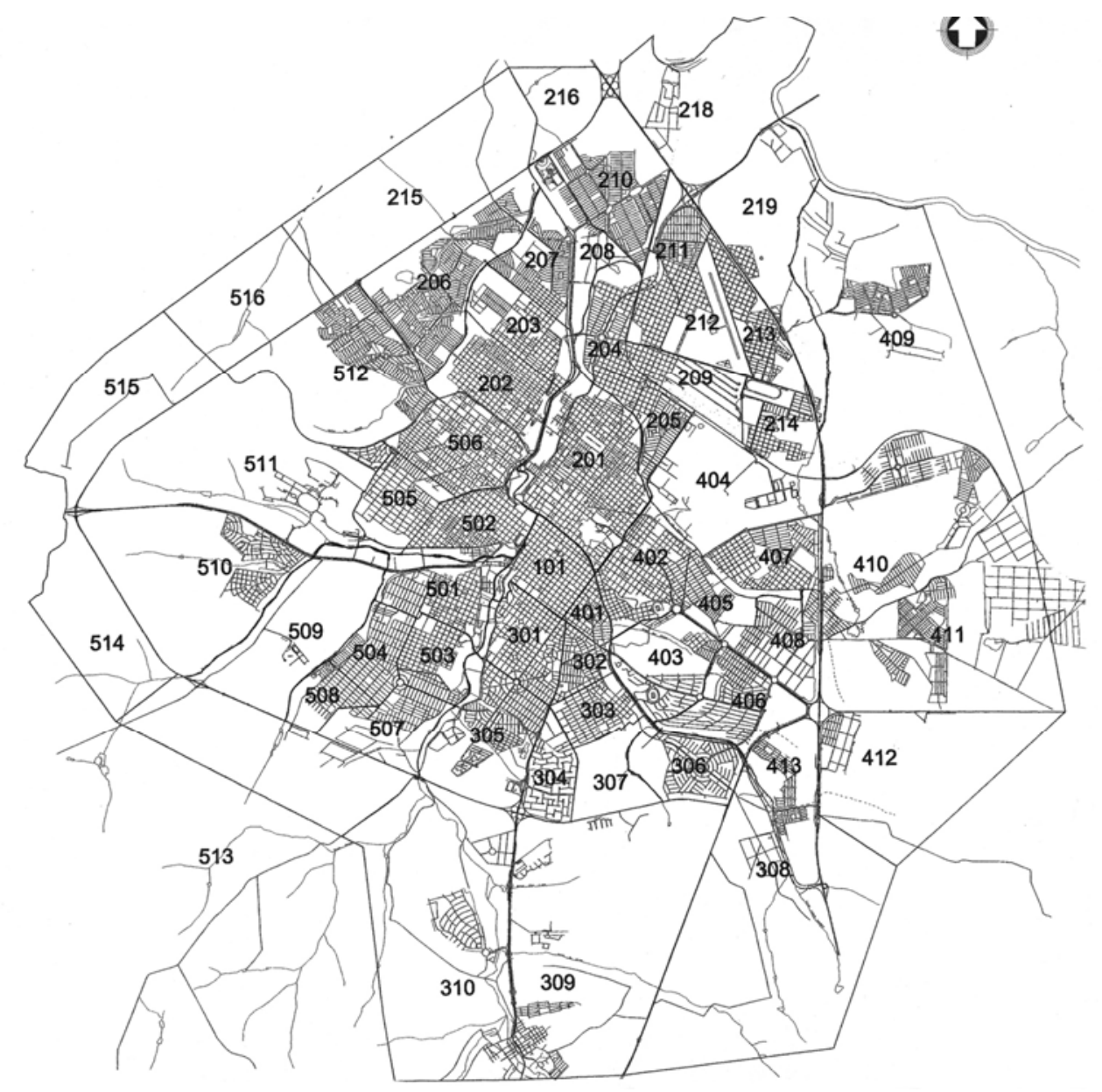


ANEXO I- Modelo do papel entregue aos adolescentes durante a entrevista

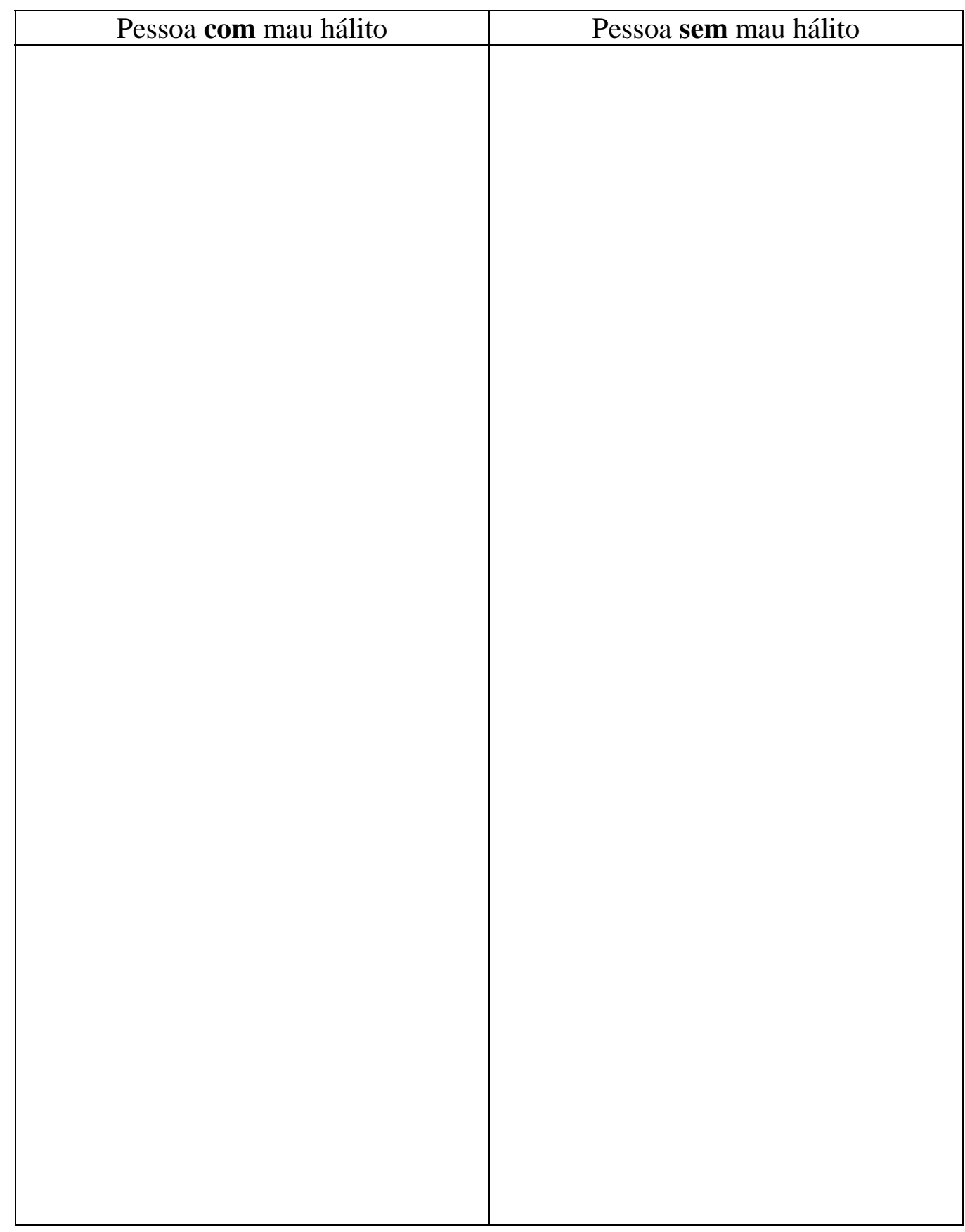

